Improved Design Basis for Laterally Loaded Large Diameter Pile: Experimental Based Approach 



\section{Improved Design Basis for Laterally Loaded Large Diameter Pile: Experimental Based Approach}

Revised Version

PhD Thesis Defended in public at Aalborg University 6 December 2013

Caspar Thrane Leth

Department of Civil Engineering, The Faculty of Engineering and Science, Aalborg University, Aalborg, Denmark

River Publishess

Aalborg 
ISBN 978-87-93102-59-0 (e-book)

Published, sold and distributed by:

River Publishers

Niels Jernes Vej 10

9220 Aalborg Ø

Denmark

Tel.: +45369953197

www.riverpublishers.com

Copyright for this work belongs to the author, River Publishers have the sole right to distribute this work commercially.

All rights reserved (c) 2013 Caspar Thrane Leth.

No part of this work may be reproduced, stored in a retrieval system, or transmitted in any form or by any means, electronic, mechanical, photocopying, microfilming, recording or otherwise, without prior written permission from the Publisher. 


\section{Preface}

This thesis "Improved design basis for laterally loaded large diameter pile - Experimental based approach" has been prepared based on physical modelling research on laterally loaded large diameter piles. I would like to thank Associate Professor Ole Hededal for facilitating the physical modelling research in the geotechnical centrifuge at Danish Techncial University (DTU) and Rasmus T. Klinkvort, Ph.D. student for discussions of and assistance with centrifuge tests. The preparation of the thesis has been carried out under the supervision of Professor Lars Damkilde, whom I would like to thank for his support and guidance.

This thesis is divided into following elements:

- Main report (present) with a discussion of the primary topics considered in the present research.

- Technical report published at Danish Technical University (DTU), Centrifuge modelling of large diameter pile in sand subject to lateral loading, describing the experimental work carried out and presenting the obtained results.

- A series of six papers prepared in relation to the research - main author of three papers and contributing author of three papers. Five papers have been published and a single is submitted.

Full reference to the technical report and the papers is given after the table of contents. The five published papers have been amended at the end of this thesis.

I had in the late autumn of 2006 the opportunity for a period of three months to visit the Centre for Offshore Foundation Systems (COFS) at the University of Western Australia (UWA), Perth, Australia. I would like to thank Professor Mark Randolph for facilitating the visit and the centrifuge team at UWA for inspiring and beneficial discussions supplemented with great inspiration in relation to centrifuge testing.

A significant part of the present thesis relates to the experimental work carried out at the geotechnical centrifuge at Danish Technical University (DTU). The renovation, upgrade and testing of/in the centrifuge has been very challenging process and I would like to thank the skilled technicians at DTU for their assistance in renovating and upgrading the centrifuge facilities.

I would like to thank a long list of friends and colleagues in COWI A/S who have supported my work, and a special thank goes to Anders Hust Augustesen, Ph.D. for his great support and never ending and round the clock readiness for discussion. Additionally I would like thank my employer COWI A/S for the opportunity to have leaves of absence for my studies.

Most importantly, I must express my greatest appreciation to my wife Kristina and our kids Arthur and Axel for their outstanding support on this extremely challenging journey - an unequalled support and patience.

Caspar Thrane Leth, Randers, December 2013 



\section{Abstract}

The development of offshore wind turbines has been in rapid growth since the construction of the first offshore wind farm in 1991 at Vindeby, Denmark. Developing from 11 turbines at a water depth of 2-6 m each with a capacity of $450 \mathrm{~kW}$ to the latest farms with up to 175 turbines each with a capacity of 3.6 MW and placed at water depths beyond $25 \mathrm{~m}$. Different foundation solutions have over the years been applied for offshore turbines, but monopiles are currently the most applied foundation type and are typically with a pile diameter of 4-6 $\mathrm{m}$ and applied up to a water depth of $25 \mathrm{~m}$. The expected development of offshore wind farms is towards larger farms, larger turbines and larger water depths. Monopiles have been applied widely and it is of interest to investigate the possibilities to further optimize the design and in particular the modelling of the soil-structure interaction. The target is to improve the use of monopiles as preferred support structure beyond the current limit at a water depth of $30 \mathrm{~m}$.

Design of foundations for wind turbines has a large focus on the stiffness of the combined structure, turbine-tower-foundation, which has an influence on the environmental loads on the structure and the productivity of the turbine. Current design practice for monopiles are based on $p-y$ curves developed for slender piles with a diameter of $0.6 \mathrm{~m}$. The focus on the structure stiffness has entailed a significant research on the soil-structure interaction for large diameter monopiles.

Comparison of the different approaches shows some discrepancy and conflicting statements, but the main findings can be summarized as:

- The standard $p-y$ curves are inadequate to describe the behaviour of lateral loaded large diameter rigid piles.

- Initial stiffness of the $p-y$ curves is depended of the diameter, depth and soil strength, and increase of each these will give an increase in stiffness.

- Cyclic response of a lateral loaded pile is depended on the characteristics of the cyclic load.

Behaviour of a monopile is a classic soil-structure interaction problem depending on the pile stiffness and the non-linear soil behaviour. The stress dependent and non-linear soil behaviour gives ground for application of physical models to understand the general behaviour of the pile, and the main objective for the present research is:

Investigate the static and cyclic behaviour of large diameter rigid piles in sand by use of physical modelling and comparison of the findings with standard $p-y$ curves.

The present research is based on use of the centrifuge facilities at Danish Technical University (DTU), the sole geotechnical centrifuge in Scandinavia. It became evident in the initial phase of the 
research that the available centrifuge facilities at DTU was outdated and the focus was changed to establish up-to-date centrifuge facilities for medium to large diameter piles, and to initiate the research on the behaviour of large diameter piles in sand under static and cyclic loading. Key elements in the establishment of up-to-date facilities has been: Equipment for controlling centrifuge tests, data acquisition, preparation of test samples and equipment for and making of lateral load tests.

The present research has been narrowed to investigate the static and cyclic behaviour of stiff piles with a diameter of 1-3 $\mathrm{m}$ in dry sand by use of centrifuge modelling and to compare the findings with the standard $p-y$ curves. It has been chosen to apply piles with an embedment length of 6 to 10 times the diameter of the applied piles.

The general static behaviour of monopiles in dry sand has based on centrifuge tests been investigated. The main focus has in the static tests been on initial stiffness and ultimate capacity, and for the cyclic tests accumulation of deformations and change in stiffness.

The main conclusion is that the static behaviour is poorly described by use of standard $p-y$ curves, where the tests show a softer initial response and a higher ultimate capacity. The initial stiffness of the soil-structure interaction measured in the centrifuge tests, equivalent to initial stiffness of $p-y$ curves, shows a dependency of depth and diameter. Control issues in relation to cyclic tests have resulted in tests with an apparent too high cyclic loading. The cyclic tests with a high utilization of the applied load vs. the static capacity shows a tendency of improvement in stiffness and ultimate capacity following the cyclic load series along with an increasing displacement with increasing number of cycles. 


\section{Resume (abstract in Danish)}

Siden opførsel af verdens første havvindmølle park i 1991 ved Vindeby I Danmark, er der sket en stor udvikling af inden for havvindmøller - I $1991 \mathrm{blev}$ der installeret 11 møller hver med en kapacitet på 450kW i et område med vanddybder mellem 2 og $6 \mathrm{~m}$, mens de nyeste parker består af optil 175 møller hver med en kapacitet på 3.6 MW og på vanddybder omkring $25 \mathrm{~m}$. I gennem årerne har der til havvindmøller været anvendt forskellige funderingstyper og i dag er monopæle den mest anvendte type med en typisk diameter på 4-6 m ved vanddybder omring $25 \mathrm{~m}$. Den fremtidige udvikling går i retning af større parker, med større møller og ved større vanddybder. Grundet de mange erfaringer med brugen af monopæle er det interessant at undersøge muligheden for at optimere designet af monopæle, specielt med henblik på samspillet mellem jord og struktur. Målet er at gøre brugen af monopæle ved større vanddybder mere attraktiv.

Ved design af fundamenter til vindmøller er der et stort fokus på stivheden af den samlede konstruktion, mølle-tårn-fundament, da stivheden har en direkte indflydelse på størrelsen af de laster som påvirker konstruktionen og møllens produktivitet. Gældende design praksis er at anvende standard $p-y$ kurver som oprindeligt er udviklet for slanke pæle med en diameter på $0.6 \mathrm{~m}$. Den øgede fokus på den samlede stivhed af konstruktionen har medført stor forsknings aktivitet inden for monopæle med store diametre. Sammenligning af de forskellige forskningsresultater viser nogen variation og i nogle tilfælde modstridende forhold - men samlet set er konklusionerne:

- Standard $p-y$ kurver kan ikke fyldestgørende præsentere opførslen af stive monopæle med store diametre.

- Initial stivheden af $p-y$ kurver er afhængig af diameter, dybde og jordens styrke, og forøgelse af hver parameter øger stivheden.

- Den cykliske opførsel af tværbelastede pæle er afhængig af udformningen af den cykliske belastning (last amplitude, last retning mv.).

Opførsel af monopæle er et klassisk jord-struktur problem, som er afhængig af pælens stivhed og jordens ikke-lineære opførsel. Jordens opførsel danner grundlag for anvendelse af fysiske modeller, som kan tage hensyn til ikke-lineariteten til undersøgelse af den generelle opførsel af pælene. Det primære formål med den nærværende forskning er:

Undersøge den statiske og cykliske opførsel af stive pæle med store diametre i sand ved brug af fysisk modellering og sammenligne de fundne resultater med standard $p-y$ kurver.

Nærværende forskning er baseret på brug af den geotekniske centrifuge på Danmarks Tekniske Universitet (DTU). Ved opstart af forskningen blev det klart at centrifugen på DTU var ikke var 
tidssvarende, og formålet blev ændret til at etablere moderne centrifuge faciliteter og påbegynde forskning indenfor den statiske og cykliske opførsel af pæle med store diametre. Hovedelementer i etablering af moderne centrifuge faciliteter er: Forsøgsstyring, dataopsamling, forberedelse af sand prøver og udstyr til og gennemførelse af forsøg på tværbelastede pæle.

Forskningen er præciseret til at undersøge statisk og cyklisk opførsel af stive pæle med en diameter på 1-3 m i tørt sand ved brug af centrifuge forsøg og sammenligne resultaterne med brug af standard $p-y$ kurver. Det er valg at undersøge pæle med en længde på 6 til 10 gange pæle diameteren.

Den generelle opførsel af monopæle i tørt sand er blevet undersøgt ved hjælp af centrifuge forsøg. Statiske pæle forsøg er brugt til at undersøge pælenes initiale stivhed og den ultimative bæreevne, mens ændringen af pælenes flytning og stivhed undersøges i de cykliske forsøg som funktion af antallet af last cykler.

Det konkluderes ud fra de udførte forsøg at standard $p-y$ kurver ikke kan beskrive den statiske opførelse, og der er ved forsøgene er observeret et mindre stift respons og en større bæreevne end forventet fra brug af standard $p-y$ kurver. Den målte initial stivhed af jord-pæl responset, svarende til initial stivheden af $p-y$ kurverne, viser en afhængighed med dybden og diameteren. Der er ved de cykliske forsøg observeret problemer med styringen af forsøgene, således at pælene er påført en relativ høj og uens belastning. Forsøgene viser tendens til forøgelse af post cyklisk stivhed og ultimativ bæreevne, samt en forøgelse af flytninger med øgede antal belastningscyklusser. 


\section{Table of contents}

Preface

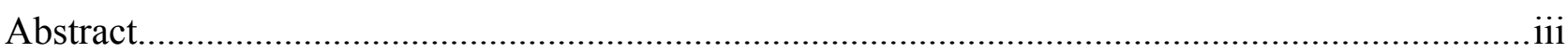

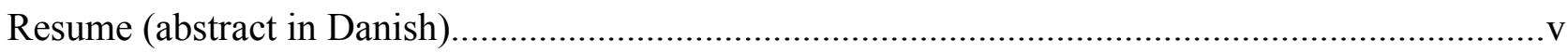

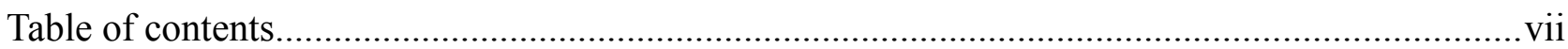

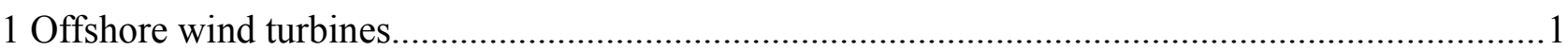

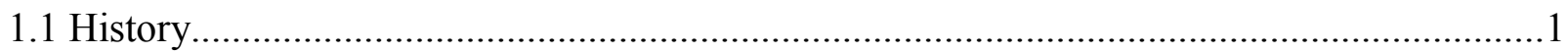

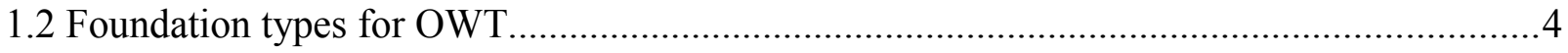

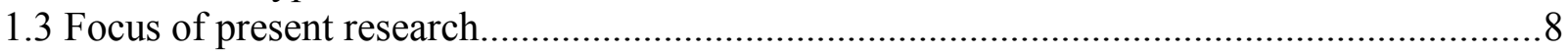

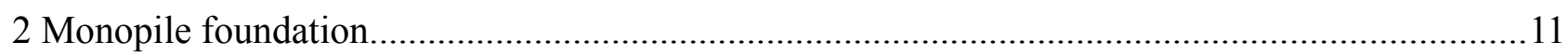

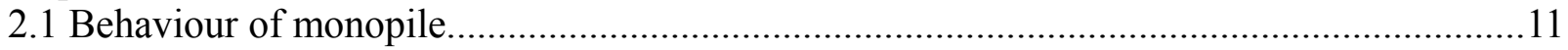

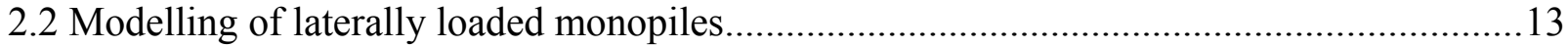

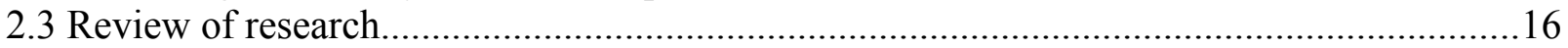

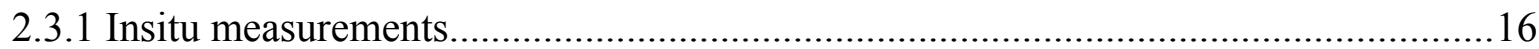

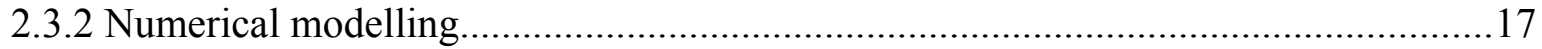

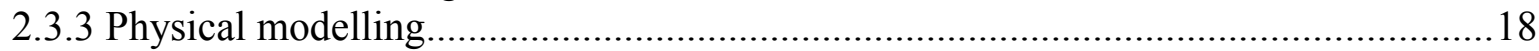

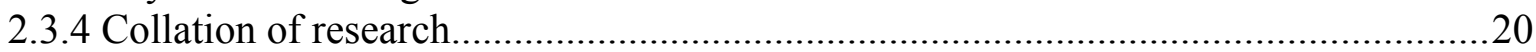

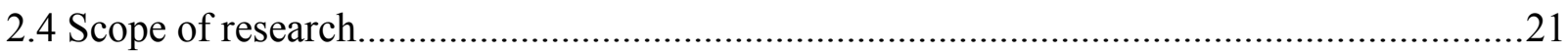

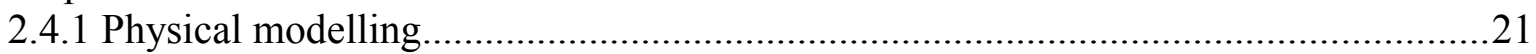

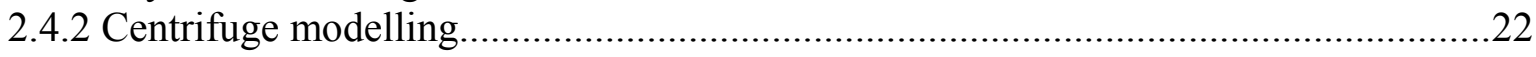

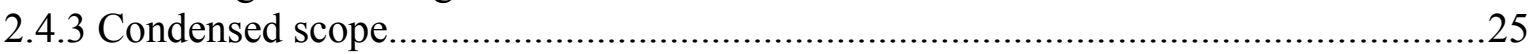

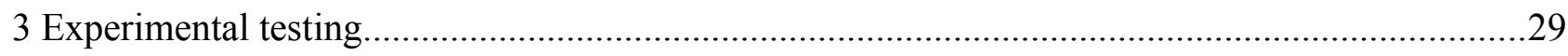

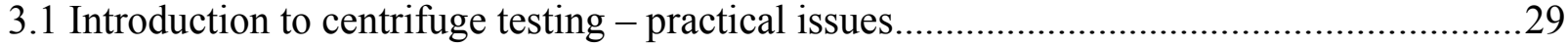

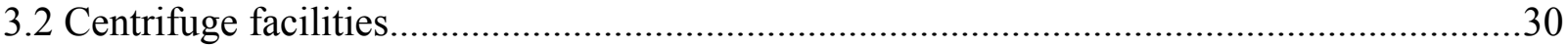

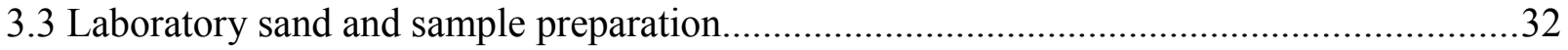

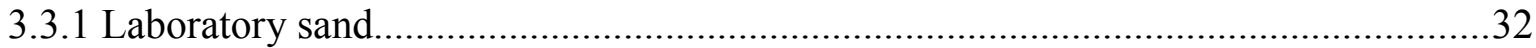

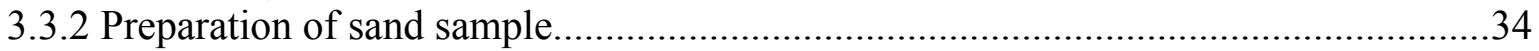

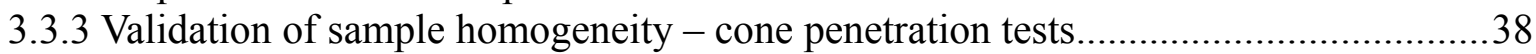

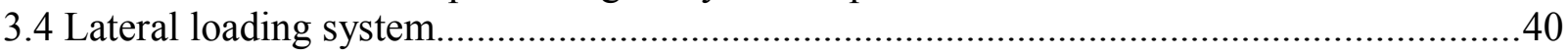

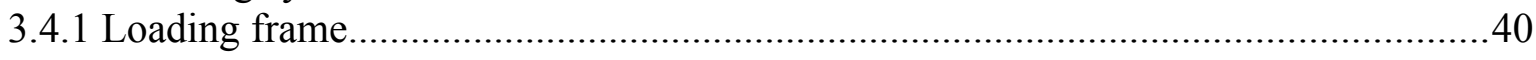

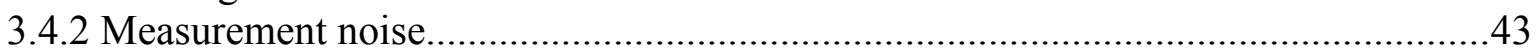

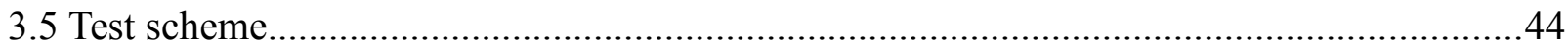

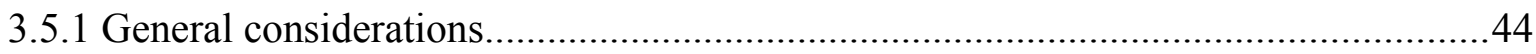

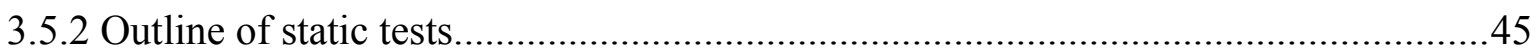

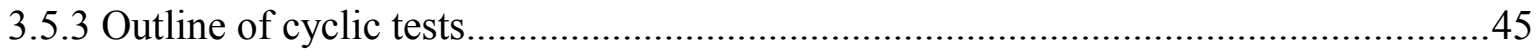

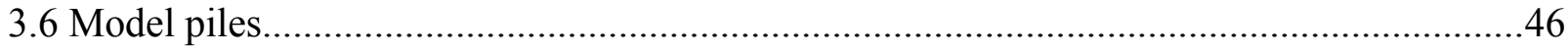

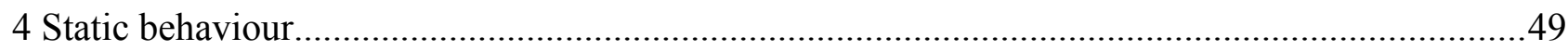

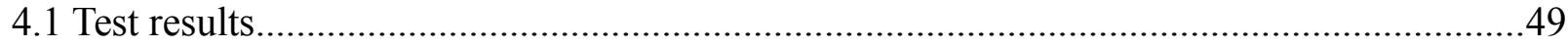

4.2 Comparison with load-displacement curves based on standard $\mathrm{p}$-y curves.........................54

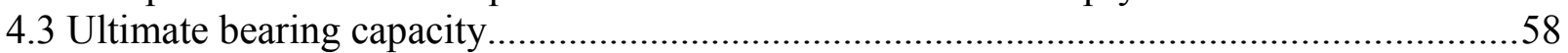

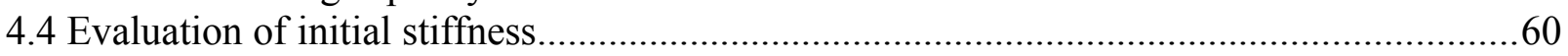

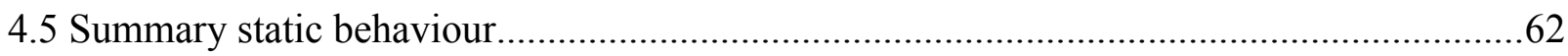




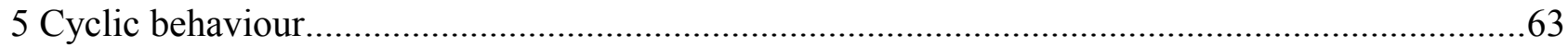

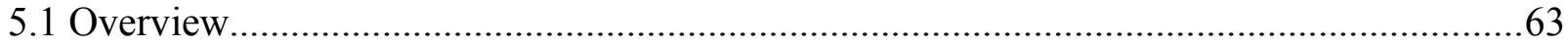

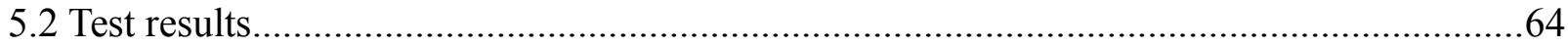

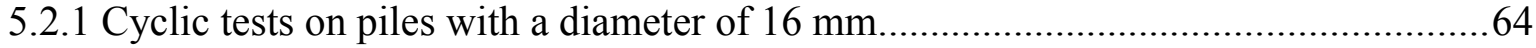

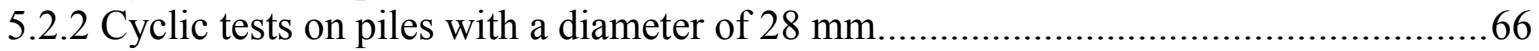

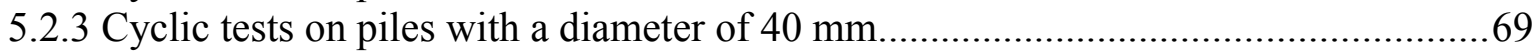

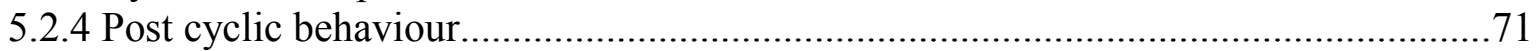

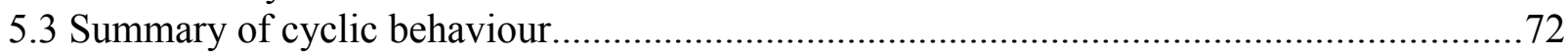

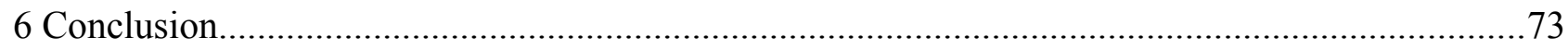

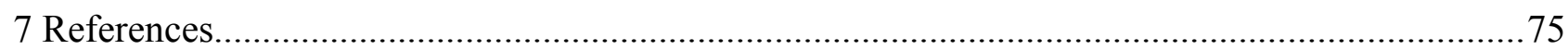

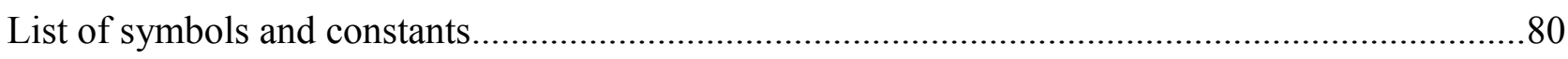

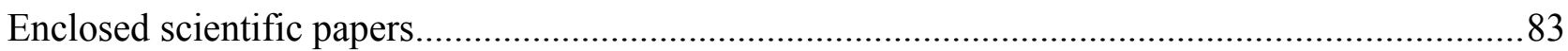

\section{Scientific papers:}

Leth, C.T., Krogsbøll, A.S. \& Hededal, O. (2008). Centrifuge facilities at Technical University of Denmark. Published in the proceedings of and presented at NGM-2008 (Nordic

Geotechnical Meeting), Nordisk Geoteknikermøte nr.15, Sandefjord, 3-6 September 2008, Norway, pp. 335-342.

Klinkvort, R.T., Leth, C.T. \& Hededal, O. (2010). Centrifuge modelling of a laterally cyclic loaded pile, Proceedings of the 7th International Conference on Physical Modelling in Geotechnics (ICPMG 2010), 28th June - 1st July, Zurich, Switzerland 2010. Vol. 2 pp 959-964. ISBN-13 978-0-415-59288-8.

Augustesen, A.H. \& Leth, C.T. (2011). Tverbelastede paele. Submitted for publication in DGFBulletin nr.17 (Dansk Geoteknisk Forening, www.danskgeotekniskforening.dk).

Klinkvort, R.T., Leth, C.T. \& Hededal, O. (2012), Centrifuge modelling of monopiles in dense sand at The Technical University of Denmark, Published in the proceedings of and presented at $2^{\text {nd }}$ European conference on Physical Modelling in Geotechnics (EUROFUGE 2012), Delft, Netherlands, 23.-24. April 2012.

Leth, C.T., Sørensen, S.P.H., Klinkvort, R.T., Augustesen, A.H., Ibsen, L.B. and Hededal, O. (2012). A snapshot of present research at AAU and DTU on large-diameter piles in coarsegrained materials. Published in the proceedings of and presented at NGM-2012 (Nordic Geotechnical Meeting), XVIth Nordisk Geoteknikermøde, Copenhagen, 9.-12. May, Denmark. pp. 491-498.

Leth, C.T., \& Damkilde, L. (2013). Unified model for laterally loaded rigid pile in sand, Submitted for possible publication. August 2013.

\section{Technical report:}

Leth, C.T. (2011). Centrifuge modelling of large diameter pile in sand subject to lateral loading, Technical University of Denmark - Department of Civil Engineering, vol. SR 11-09 (UK) - Technical report. Available as download from DTU Orbit, orbit.dtu.dk. 


\section{Offshore wind turbines}

\subsection{History}

The history of electricity production by use of wind goes back to 1887 where the Scottish professor James Blyth build a wind turbine to power his holiday cottage.

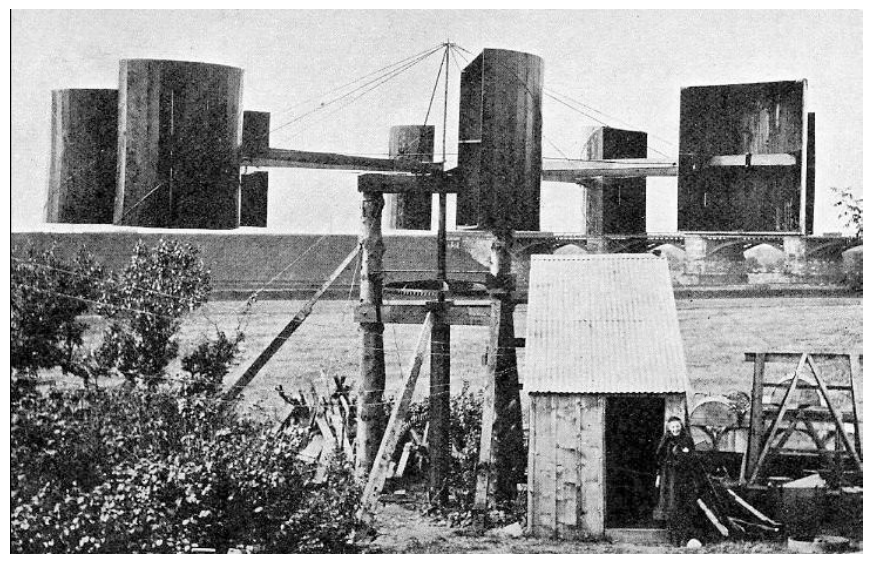

Figure 1.1 James Blyth's "Windmill" from 1891.(from www.wikipedia.com)

Through the first third part of the 20th century wind power was an important element in decentralized production of electricity, and it was widely used due to lack of distribution system. With development of the power distribution system the use of wind generated power decreased.

With the oil price crisis in the early 1970s focus were set on the use of wind energy as a competitive source of renewable energy and development of large commercial wind turbines accelerated. The first multi-megawatt was build in 1978 by students and teachers from the Tvind school, Figure 1.2.

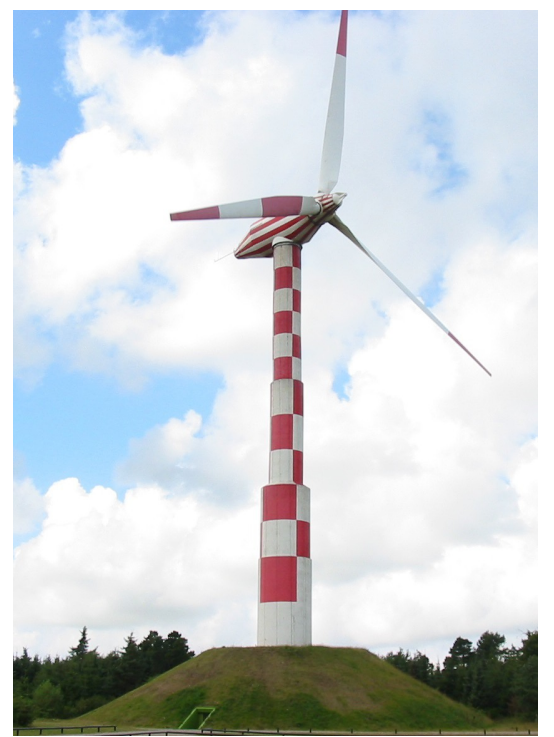

Figure 1.2 2MW Tvindmølle constructed in 1978 (from www.wikipedia.com). 
In the late 1980s increasing interest for using renewable energy in Denmark and a high population density caused a Danish power company, Elkraft, to anticipate difficulties for use of large onshore wind farms. This lead to the idea of placing wind turbines offshore.

In 1991 the world's first offshore wind farm was constructed in Vindeby, Denmark. The farm is in 2012 still in operation and consists of 11 turbines each with a capacity of $450 \mathrm{~kW}$. The turbines are placed on gravity foundations in an area where the water depth range is 2-6 m.

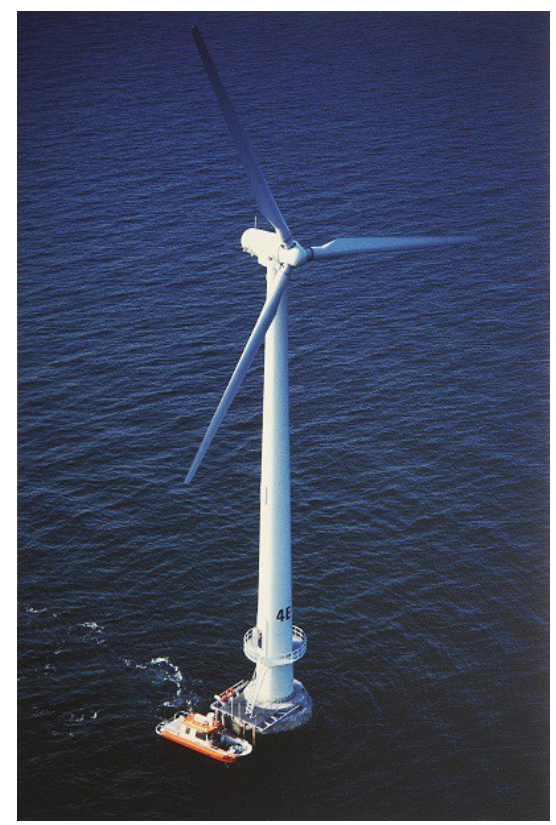

Figure 1.3 Bonus $450 \mathrm{kW/37}$ turbine at Vindeby (from www.lorc.dk)

The offshore wind farm in Vindeby became the starting point for an new industry with an extreme development potential. The focus on renewable energy as a future energy source able to battle the dependency of fossil fuelled power generation increased the interest in wind power as a competitive source.

The use of wind power requires large production units (wind farms), to ensure a reasonable production. The advantage of bringing the wind production offshore is a stronger wind, which is more constant and less turbulent due to low terrain roughness. An important element in the consumer satisfaction is that visual pollution for the neighbour from a significant number of large wind turbines is avoided. Additional challenges are experienced when the wind energy is brought offshore compared to traditional land based solutions, among other: Higher construction costs, harsh environment and reduced accessibility for service.

Figure 1.4 shows the development in offshore wind capacity during the two decades following construction of Vindeby wind farm, the total number of offshore wind farms in 2010 was 45 across nine countries (EWEA 2011). 


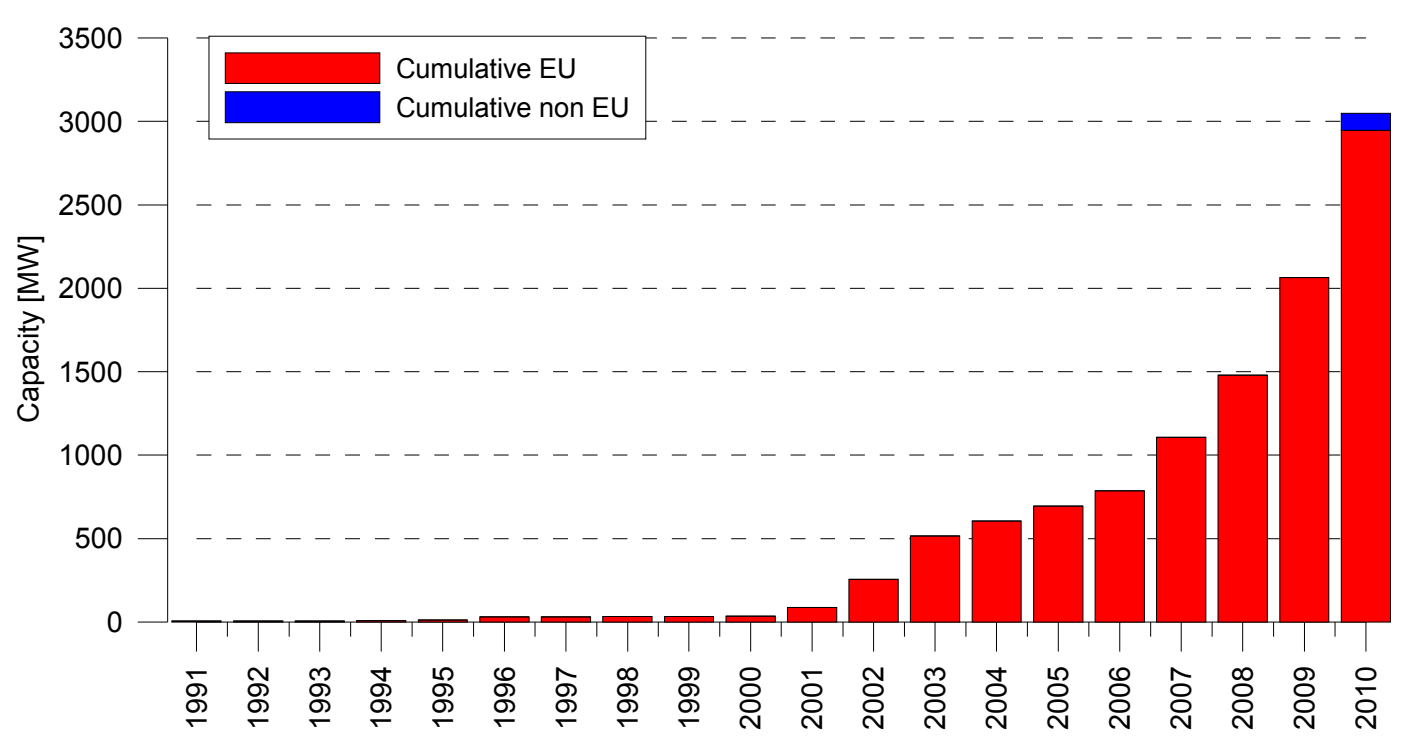

Figure 1.4 Development in offshore wind capacity, 1991-2010 (from EWEA 2011)

The complexity of offshore electricity production is higher than traditional onshore production, and with the goal of optimizing the possibilities offshore the interest is to increase the size of the applied turbines. Larger turbines reach higher altitudes where the wind conditions are better, wind speed improves and in addition the turbulence reduces with altitude. An important advantage with offshore farms and turbine sizes is that logistics with large turbine components are significant better when having a large part of the transportation offshore, compared to the transport to onshore sites with potential narrow roads and low bridges. The first offshore park had turbines with a capacity of $450 \mathrm{~kW}$ whereas the new parks under construction utilizes turbines with a capacity of $3.6 \mathrm{MW}$. The development of turbine sizes continues and current plans for new farms involves turbines with capacities of 6 and $7 \mathrm{MW}$.

The combination of increasing the turbine sizes and use of large farms increases the requirement of available space. This drives the available locations further offshore in order to avoid cables, shipping lanes and protected areas. The first offshore farms were located close to shore, Vindeby is approximate $1.8 \mathrm{~km}$ off the coast, while the newer farms have been moved further away, e.g. $20 \mathrm{~km}$ for London Array phase 1 which is under construction. 


\subsection{Foundation types for OWT}

Increased turbine size and increasing water depths due to further distance to shore increases the loads acting on the turbines and thus the requirements for the foundation structure. Different types of foundation structures can be applied for the turbines, and the most common are illustrated in Figure 1.5; from left to right equals from shallow to deeper water.

a) Gravity foundation

b) Monopile foundation

c) Bucket foundation

d-e) Tripod / jacket foundation

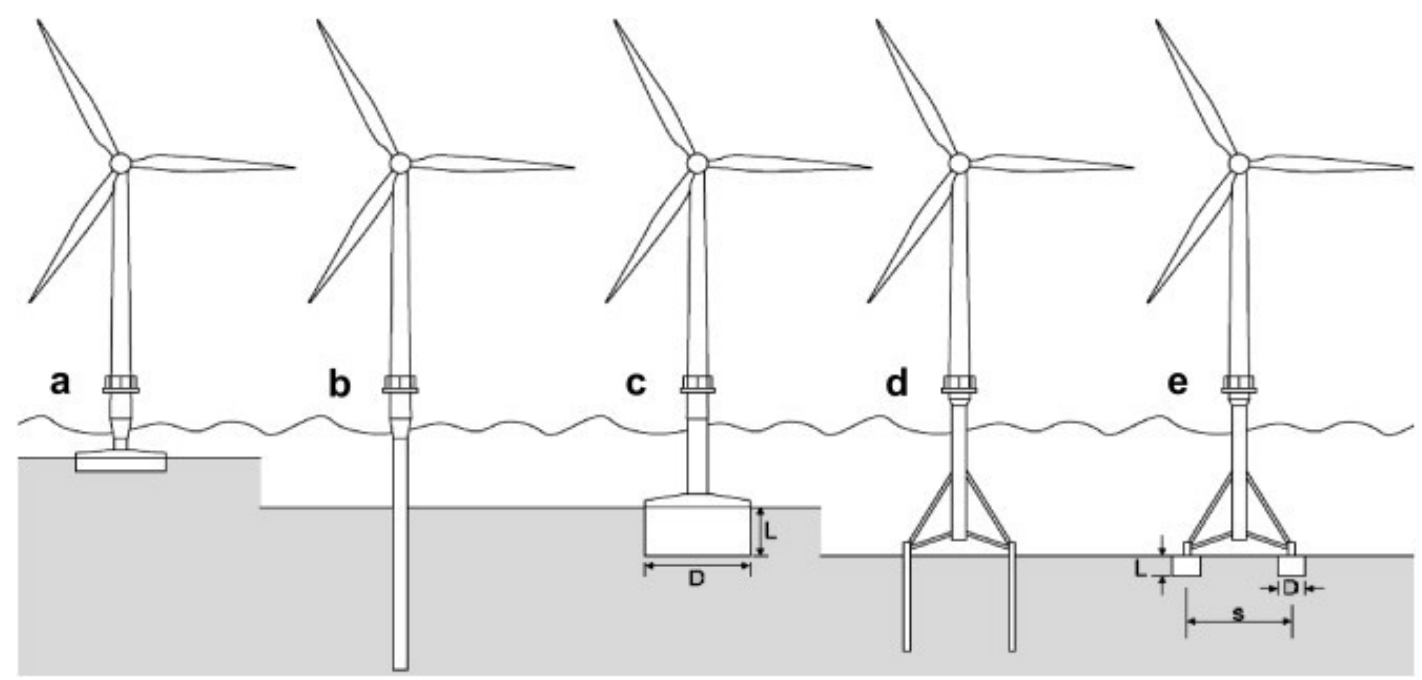

Figure 1.5 Foundation structures for Offshore Wind Turbines (from Breton \& Moe 2009)

\section{Gravity foundation:}

In general the gravity foundation represents the most common type of onshore foundation, where the loads are transferred directly from the base of the foundation to the soil. The lateral load is transferred to the soil as shear at the base of the foundation block whereas the mass of the block is used to resist the overturning moment of the structure. Offshore gravity foundations typically are reinforced concrete caissons (Figure 1.6) which on-site is filled with ballast material to ensure sufficient weight of the combined structure to ensure stability. The size of the foundation base and the mass of the structure is related, hence with a large base a smaller total mass is needed to ensure stability of the foundation.

A gravity foundation represent a volume of structure placed on the seabed, and thus will the loads from wave and current represent a significant contribution to the total loads on the structure. The forces on the gravity foundation is transferred to the soil directly beneath the foundation and 
requires competent soils near the seabed. In addition the seabed must be prepared prior to installation; i.e. removal of soft soils, objects and subsequent levelling with a proper coarse material (gravelbed). These issues implies increasing difficulties (and expenses) with increasing water depths and causes the foundation type to be more favourable at shallow water depth. The gravity foundation has primary been applied up to a water depth of $10 \mathrm{~m}$, and with a base diameter in the range of $25-30 \mathrm{~m}$.

Offshore turbines are usually mounted directly to the gravity foundation, and the vertical alignment of the tower is ensured by careful levelling of the gravel bed below the base.

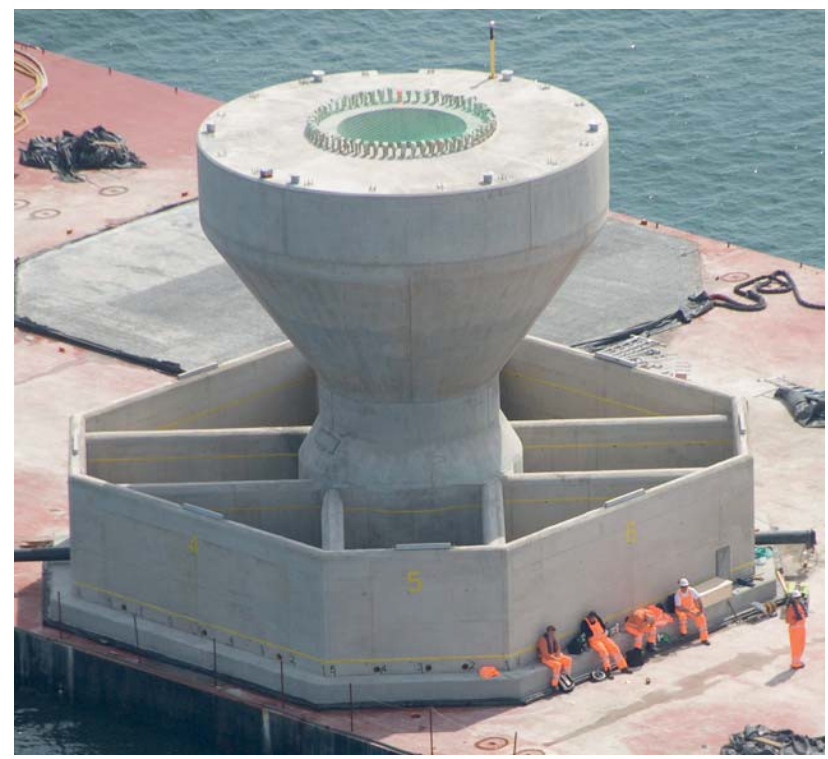

Figure 1.6 Gravity foundation (from www.no-tiree-array.org.uk)

\section{Monopile foundation:}

The monopile foundation is typical a large steel cylinder installed by pile driving or drilling. The loads are transferred to the soil by bending of the pile and lateral earth pressures acting on the pile. Pile dimensions for the latest installed offshore wind parks are 4-6 $\mathrm{m}$ with an pile embedment length of 20-35 m. Monopiles are typically applied up to a water depth of $25 \mathrm{~m}$, and are currently the most applied foundation type.

Main concerns for the use of steel monopiles are: Corrosion, fatigue and combined stiffness of the structure and soil. The handling of the long large diameter piles is an issue along with the needed force to install the piles.

A transition piece is usually used to connect the offshore turbine to the monopile. The connection between the cylindrical transition piece and the pile is in the installation phase adjustable making it possible to take any misalignment of the pile into account prior to fixing the parts with a grout connection. 


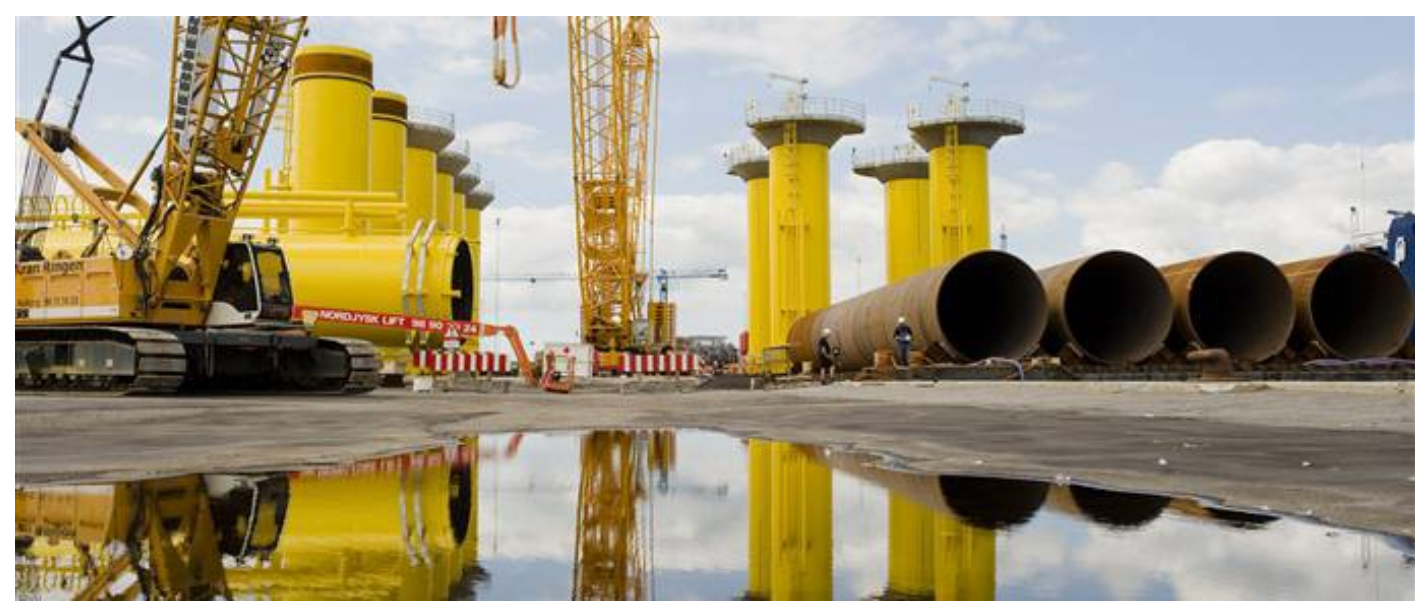

Figure 1.7 Monopile and transition pieces (from www.abjv.com)

\section{Bucket foundation:}

The bucket foundation is a relative new foundation type under development for offshore wind turbines. The foundation concept is developed from suction anchors applied in the offshore oil and gas industry. The bucket is basically a steel cylinder closed at the top end and installed by a combination of self weight and suction applied inside the cylinder. The forces acting on the bucket during operation are transferred to the soil as shear and lateral earth pressure on the skirt along with end beading of the bucket.

The bucket foundation concept has been applied for a test turbine in Frederikshavn, Denmark, and a series of met masts applied for measurements of offshore wind and climate conditions. The concept has yet to be applied for an offshore wind park and current research is on the stability of the skirt to avoid instability and damage during installation. Current applied dimensions are a diameter up to 16 $\mathrm{m}$ and an height of $1 / 2-1$ times the diameter.

The supported structure (offshore turbine / met mast) is mounted directly on the top of the bucket foundation and levelling of the bucket is ensured during installation.

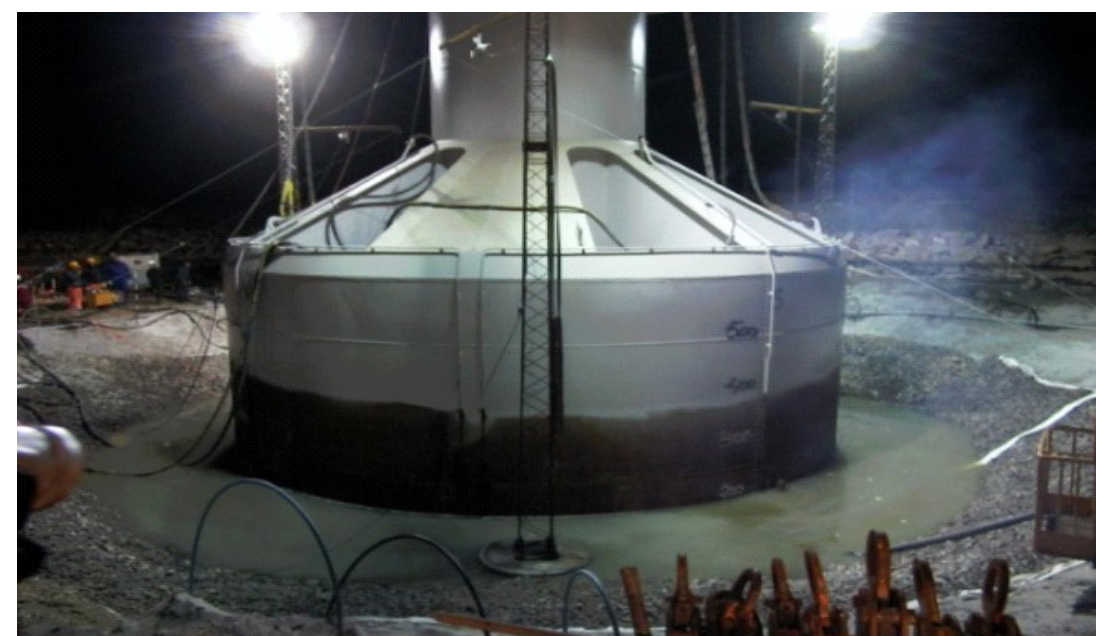

Figure 1.8 Bucket foundation for 3 MW test turbine at Frederikshavn, Denmark (Larsen 2012) 


\section{Tripod/jacket foundation:}

The cost of traditional applied foundations, gravitational and monopile, increases significant for water depths above 30-35 $\mathrm{m}$ and the applied foundation solution becomes a tripod or jacket structure. Both types are developed and applied for the offshore oil and gas industry. The tripod and jacket are both steel structures which typical are founded with piles, but bucket foundations can be applied.

A tripod foundation consists of a main pipe and three legs, where the turbine is connected to the main pipe, see Figure 1.9. The jacket foundation is a frame structure where the turbine is mounted on the top, see Figure 1.10. Forces on the foundation structures and the turbine are transferred to the soil as a lateral earth pressure and a combination of compression and tension on the foundations (piles or buckets).

The tripod and jacket are for the case with piles levelled prior to fixing the piles and steel structure by a grout connection. When applying bucket levelling is ensured during installation by application of different penetrations of the buckets.

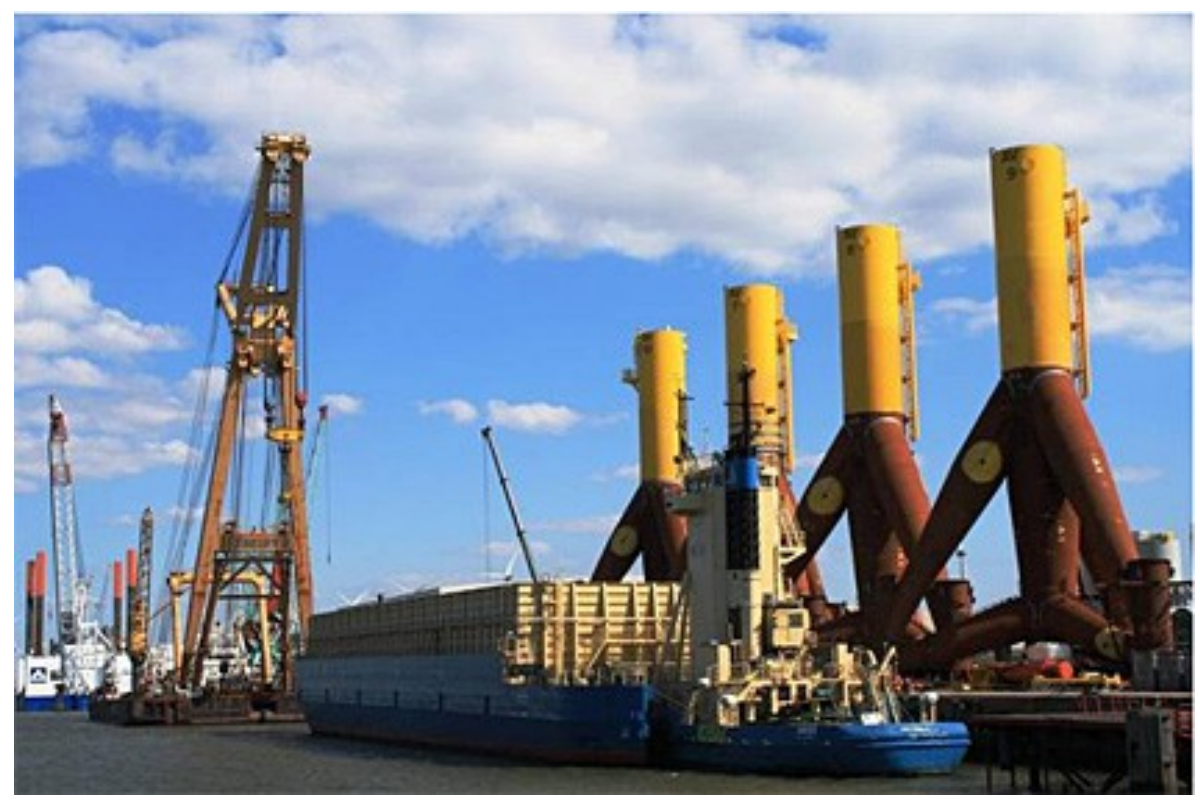

Figure 1.9 Tripod foundation for Alpha Ventus OWF (from www.areva-wind.com) 


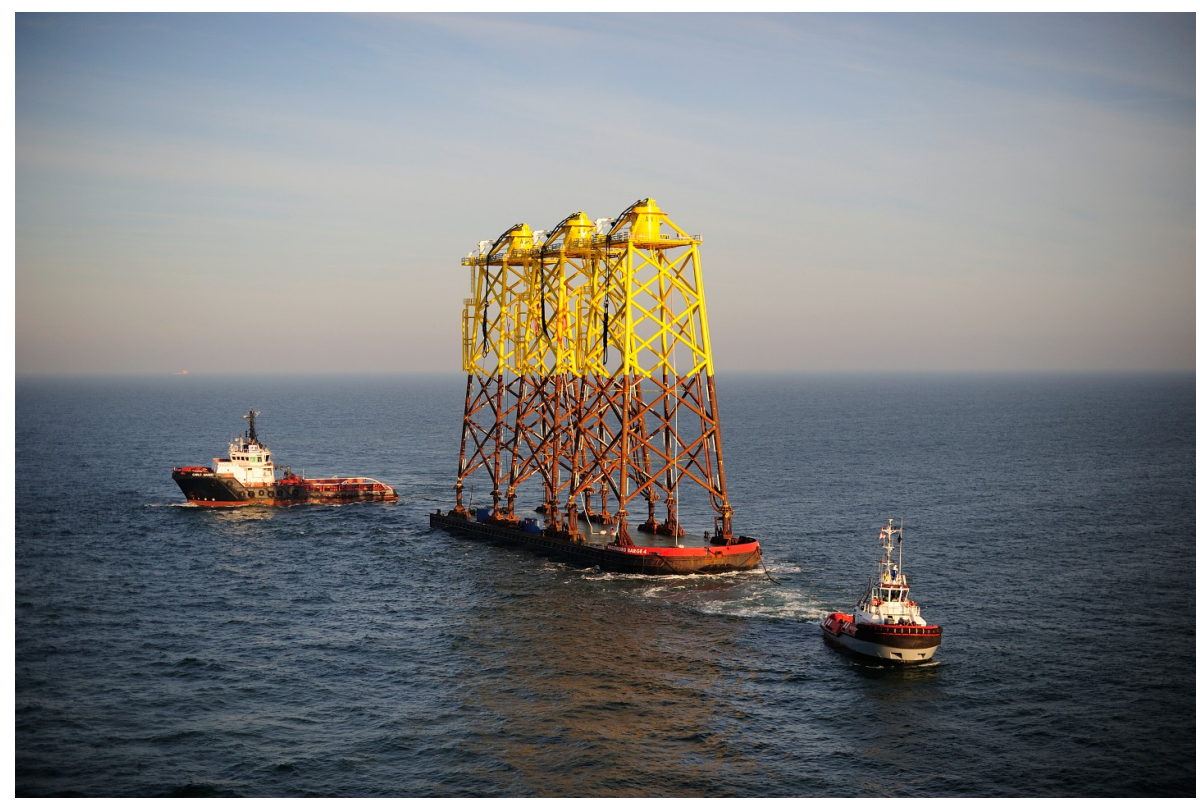

Figure 1.10 Jacket foundation for Alpha Ventus OWF (from www.lorc.e-kvator.com)

\subsection{Focus of present research}

The most applied foundation type for offshore wind farms are currently monopiles, which typically are applied at water depths up to $25 \mathrm{~m}$. The expected future development of offshore wind farms is moving towards larger farms, with larger turbines and located at larger water depths.

Several assessments have been made regarding applicable support structures for future offshore wind turbines, and in UpWind (2007) eight different types of support structures have been considered for a water depth range of 30 to $120 \mathrm{~m}$. The considered structures are: Monopile, Tripod, Jacket, Gravity base, suction bucket, compliant tower, floating barge, floating tension leg and floating spar (see UpWind 2007 for further information on the different types).

The assessments in UpWind (2007) consider the different stages in the life cycle of the turbine from design to decommissioning. The main findings in UpWind (2007) are that Monopile, Tripod, Jacket and gravity foundations are dominant to a water depth of approximate $60 \mathrm{~m}$ after which the floating structures preforms best. For the water depth range of 30-60 m, the monopile performs best at a depth of $30 \mathrm{~m}$, after which the jacket and tripod structures dominates until a depth of $60 \mathrm{~m}$. The gravity based structure has the worst performance of the 4 types.

The main issue for monopiles is that for larger water depths the fatigue loads, with the present design methods, becomes more critical and that the dimensions and thus weight of the piles increases significant. This makes the practical handling of elements to the support structures very challenging (expensive) if possible at all.

A significant experience has been build up in the use of monopiles and it is of interest to investigate the possibilities to further optimize the design and in particular the soil structure interaction, with 
the target of improving the use of monopiles as preferred support structure beyond the current limit at a water depth of approximate $30 \mathrm{~m}$.

It is for the present research chosen to investigate the monopile foundation concept related to foundation of offshore wind turbines and improve the design basis. This is further narrowed to consider dense to very dense sand. 



\section{Monopile foundation}

\subsection{Behaviour of monopile}

The loading on an OWT founded on a monopile consists of a series of different load types, cf.

Figure 2.1:

1. Wind on blades and nacelle

2. Wind on tower

3. Wave and current on monopile/tower

4. Mass of structures

5. Aero dynamic effects from blades passing tower.

In general it is a 3 dimensional loading scheme and the resulting loads acting on the top of the pile are illustrated in Figure 2.2. The loading consists of a primary and a secondary load direction, each with a horizontal load and a corresponding moment. The load in the secondary direction is compared to the primary load for normal conditions very small and is usually omitted in design of the foundation structure.

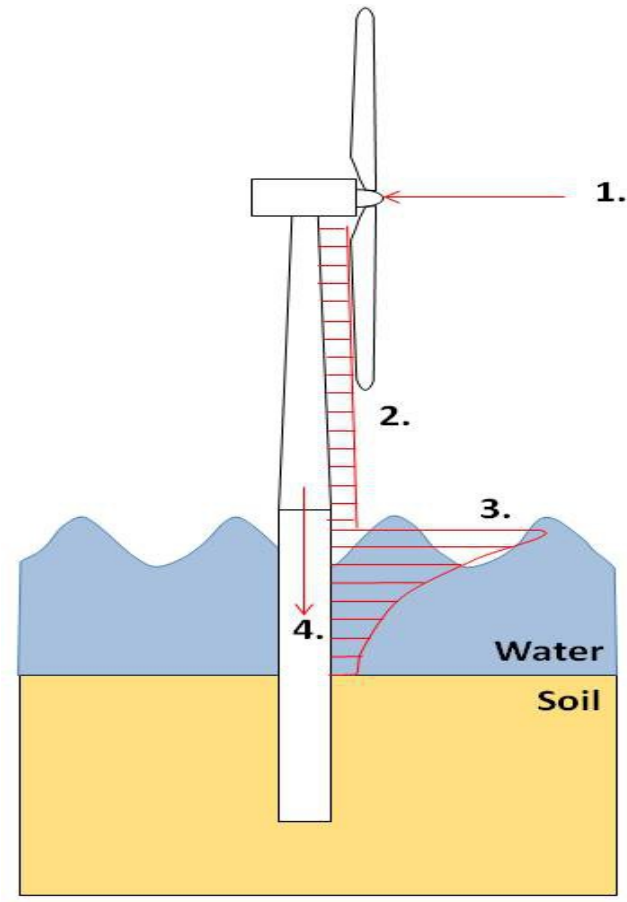

Figure 2.1 Loads on OWT founded on monopile.

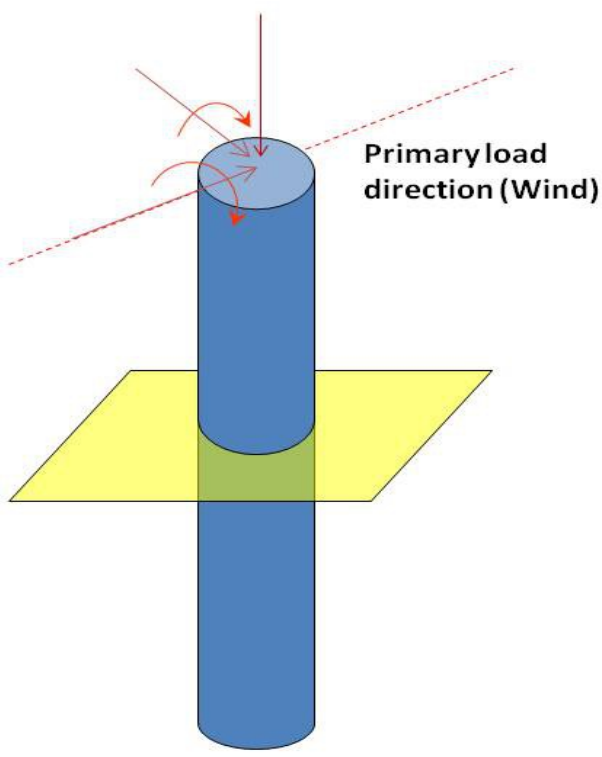

Figure 2.2 Loads on monopile. 
The vertical load acting on the top of the monopile, mass of the structure, is distributed to the soil as vertical shear and/or end bearing of the pile. The horizontal load and moment is transferred to the soil by rotation and bending of the pile, and is resisted by mobilized lateral earth pressure.

The earth pressure response develops with displacement of the monopile and the distribution of the earth pressure along the pile length depends on the actual behaviour and thus stiffness of the pile. A flexible pile will have the lower part of the pile fixed and the upper part bending in a S-shape, cf. Figure 2.3, while a stiff pile exhibits a rotational behaviour, cf. Figure 2.4.

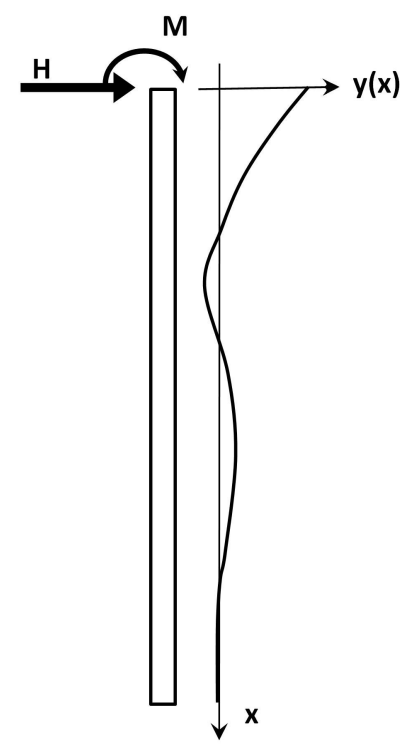

Figure 2.3 Behaviour of flexible pile.

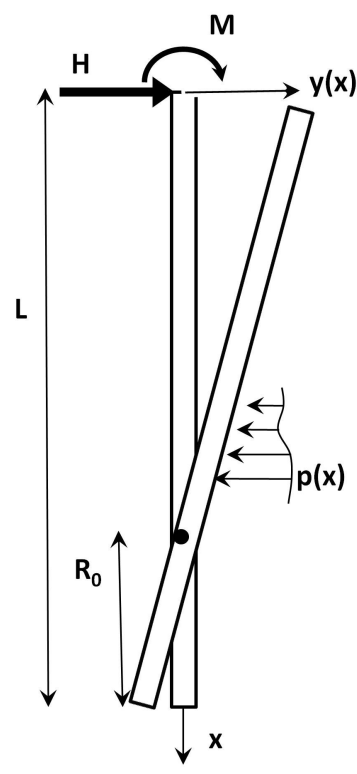

Figure 2.4 Behaviour of stiff pile.

Design of foundations for wind turbines focuses primarily on the stiffness of the combined structure, turbine (tower and foundation) and the turbine supplier has strict requirements to keep the first natural eigenfrequency of the structure within a specified frequency range. The stiffness of the structure has a direct influence on the environmental loads on the structure and the productivity of the turbine.

The objective for design of OWT foundations is to resist large horizontal and moment loads, with a sufficient stiffness to ensure stable operational conditions during the lifetime of the turbine. The vertical load (mass) is very small, and not governing the design causing vertical equilibrium to be merely a verification calculation. 


\subsection{Modelling of laterally loaded monopiles}

The general behaviour of a laterally loaded monopile is a fully three dimensional problem involving complex soil and soil-structure behaviour including stress, strain and time dependent effects. The soil-structure interaction includes:

- Pile stiffness

- Static behaviour of soil / cyclic behaviour of soil

- Stratification and interaction between the layers.

The focus on predicting the behaviour of lateral loaded piles, aside from the calculating the ultimate capacities, increased in the 50ties, and a milestone was reached by presentation of the basic principles for the $p$-y curve method, McClelland \& Focht (1958) and Reese \& Matlock (1956).

The $p$-y curve method is based on modelling the pile as an Bernouilli-Euler beam on uncoupled non-linear springs, Figure 2.5. In the 70ties the research in $p$ - $y$ curves resulted in presentation of semi-empirical definitions for soft clay, sand and stiff clay (Matlock 1970, Reese et al. 1974 and Reese et al. 1975, respectively).

The $p$-y curve method has since the 70ties been the preferred design method for laterally loaded piles and is the current method recommended by the usual applied offshore regulations (e.g. API 2007).

Analysing a lateral loaded pile by use of the $p-y$ curve method can by relative simple means be

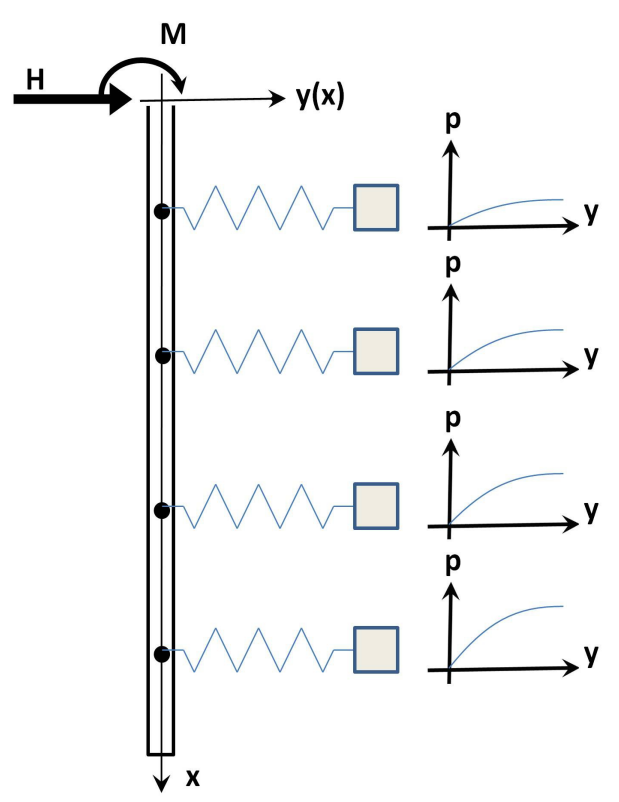

Figure 2.5 Bernouilli-Euler beam on uncoupled nonlinear springs. automatized and programmed enabling an efficient design process for monopiles.

The most important reference with respect to $p-y$ curves for sand is Reese et al. (1974), which is based on full-scale tests on piles installed on Mustang Island, Cox et al. (1974). The tests on Mustang Island were performed on long slender piles - embedment length $(L)$, wall thickness and diameter $(D)$ equal to $21.0 \mathrm{~m}, 9.5 \mathrm{~mm}$ and $0.61 \mathrm{~m}$ respectively giving a $L / D$ of 34.5 . The static tests on Mustang Island were carried out with a horizontal force acting $0.3 \mathrm{~m}(0.5 \mathrm{D})$ above groundline and the piles were displaced 5\% of the diameter (Reese et al. 1974 and Cox et al. 1974). 
The $p$ - $y$ curve formulation given by Reese et al. (1974), was along with three other methods studied by Murchison \& O'Neill (1984) by analysing data from 14 static and cyclic tests distributed on 10 different sites. The diameter of the piles varied from $0.05 \mathrm{~m}$ to $1.22 \mathrm{~m}$. Based on the study Murchison \& O'Neill (1984) suggested a revised formulation of the $p-y$ curves based on a hyperbolic tangent function, illustrated in Figure 2.6. This expression is currently in use in the present regulations as API (2007). It is general accepted that the application of the standard $p-y$ curves is valid for piles with a diameter of up to approximately $2.5 \mathrm{~m}$, DNV (1992).

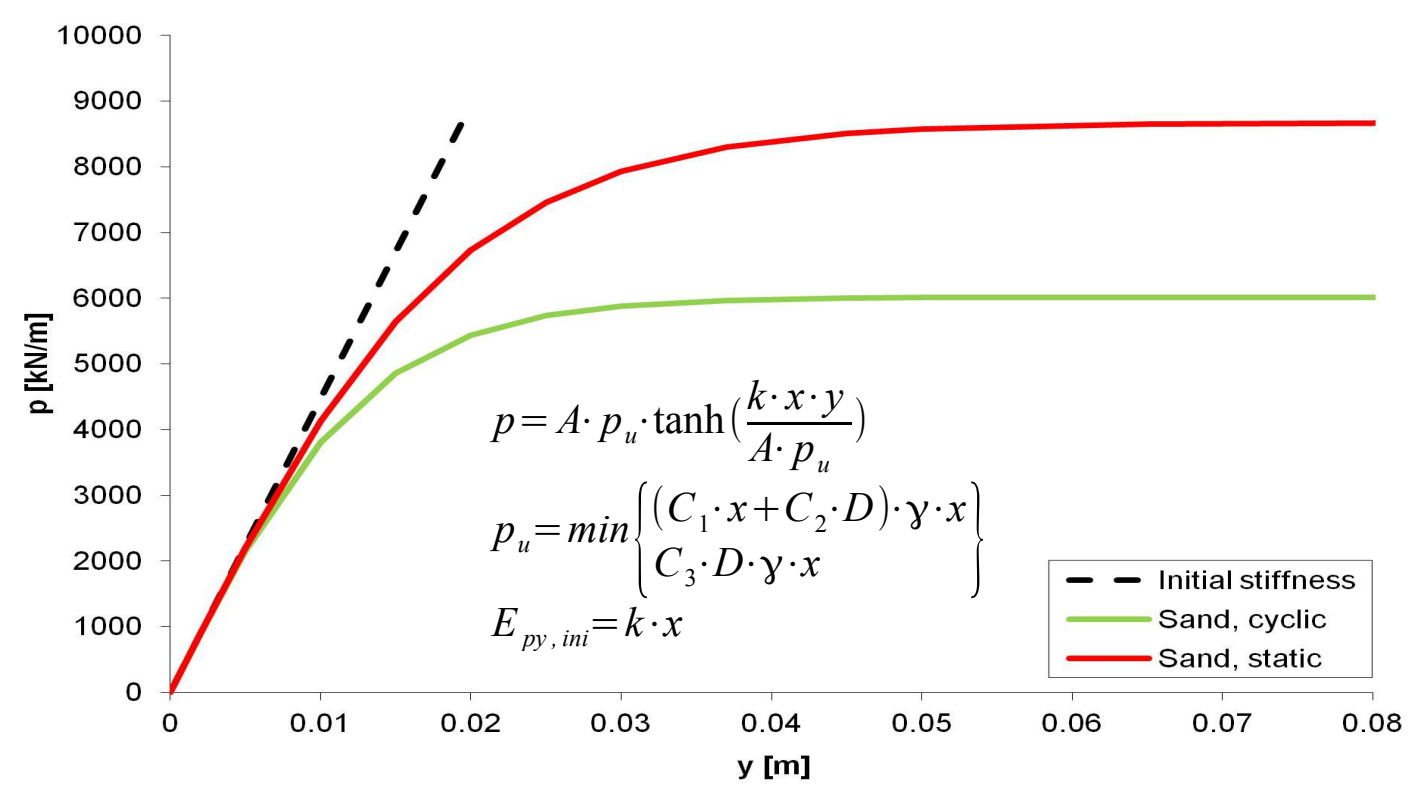

Figure 2.6 p-y curve for sand, as suggested by Murchison \& O'Neill (1984).A, C1, C2 and C3 are empirical factors. $k$ is initial modulus of subgrade reaction. $p_{u}$ is the ultimate capacity, $D$ is diameter, $x$ is depth below surface, $y$ is the displacement. $\gamma$ is the unit weight. $E_{p y, \text { ini }}$ is initial stiffness of $p$-y curve.

The increasing sizes of the applied offshore turbines and the tendency of moving the wind farms to areas with larger water depths increases the environmental loads and thus the pile size. Recently installed piles in cohesionless soils have diameters of 4 to $6 \mathrm{~m}$, wall thicknesses of 60-90 $\mathrm{mm}$ and a pile slenderness ratios (length $(L)$ /diameter $(D))$ of 5-6, representing relative rigid piles.

The transition from slender to rigid piles questions the application of the presented $p-y$ curve formulation, as pile behaviour is governed by the flexibility of the pile related to the stiffness of the soil.

Over the last two decades the use of numerical models have increased in engineering in general, and a significant number of tools have been developed for analysing three-dimensional problems. The most applied tool is the Finite Element Method (FEM), with use of a variety of constitutive models for the soil. The application of the advanced numerical models makes it possible to include a vast number of different effects in the analyses; e.g. complex geometry, behaviour of soil-structure interaction (interface), non-linear soil behaviour including cyclic behaviour and possible time- 
dependent effects. A numerical model is capable of giving the needed types of results with respect to both stiffness and strengths, where the usability and quality of the results indeed depend on the applied conditions and the understanding of the analysed structure/problem. Due to the complex nature of geomechanics and the soil-structure interaction it is no easy task to prepare and apply Finite Element Models for structural and geotechnical design of OWT, and implies a series of verification models.

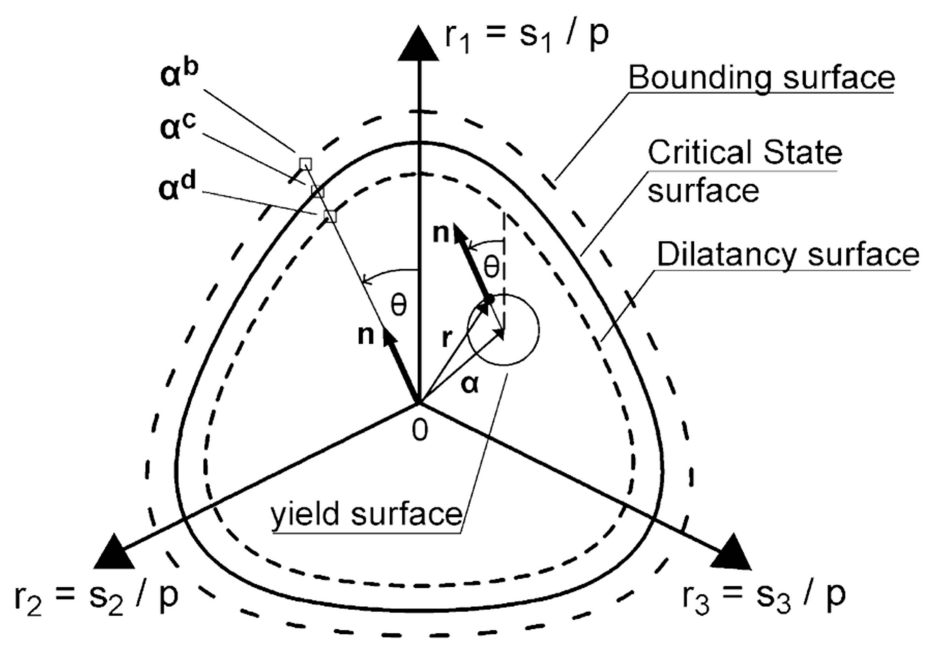

Figure 2.7 Sample of constitutive model surface in multiaxial stress space, Papadimitriou \& Bouckovalas (2002).

A design failure of large diameter piles, with respect to either excessive deformations or bearing capacity failure, based on the use of standard $p-y$ curves for sand have yet to be published. This indicates some robustness, but the extrapolation of the standard $p-y$ curves from small diameter slender piles to large diameter rigid pile, is questioned for both the static and the cyclic behaviour. The primary issues concerning the validity of the standard $p-y$ curves for large diameter piles are:

- The initial stiffness of the curves and description of the static elasto-plastic behaviour.

- The behaviour with respect to cyclic loading regarding both change in stiffness, accumulation of deflections and ultimate bearing capacity.

Following elements/methods are in general applied in research for analysing the use of standard $p-y$ curves for design / analyses of OWT

- Insitu measurements

- Numerical modelling by use of Finite element method (FEM) or Finite difference method (FDM)

· Physical modelling 


\subsection{Review of research}

\subsubsection{Insitu measurements}

One of the wind turbines at Horns Rev Offshore Wind Farm of the West Coast of Denmark has been instrumented and monitored over a period of 2.5 years. The measurements during operation indicate a significant stronger soil response than predicted by the standard $p-y$ curves (Hald et al. 2009), with a smaller pile response, deflection and bending moment. The pile diameter is $4.0 \mathrm{~m}$ and the embedment length is $23.2 \mathrm{~m}$ in medium dense to very dense sand. Analysis of the obtained data showed some problems with the applied gauges and the presented study concentrated on a period where calibration had been possible (yawing operations).

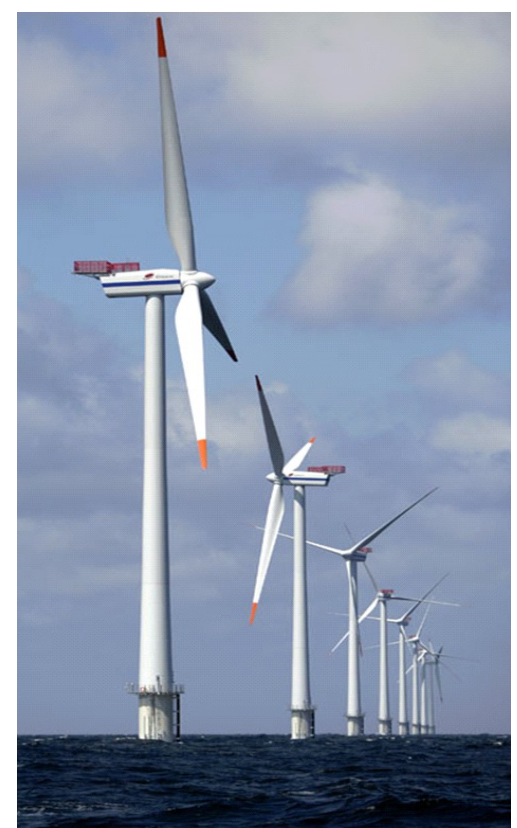

Figure 2.8 Wind turbines at Horns Rev (www.hornsrev.dk)

The initial stiffness of $p-y$ curves was investigated from a series of vibration tests on cast-in-drilledhole piles with diameter from 0.4 to $1.2 \mathrm{~m}$ (Ashford \& Juirnarongrit 2003). The piles had a length of 4.5 and $12 \mathrm{~m}$ and were embedded in weakly cemented sand. The tests showed that the initial stiffness of the $p-y$ curves with respect to natural frequencies was independent of pile diameter. The diameter effect on pile stiffness was further considered in Pender et al. (2007), where effect of different stiffness variation with depth was investigated for a long elastic pile in elastic medium. A main conclusion was that the diameter effect is a consequence of the distribution of the initial stiffness of the $p-y$ curves, and for a stiffness increases with depth an increasing diameter will give increasing lateral stiffness. In addition Pender et al. (2007) concluded that there is a significant influence on the pile head stiffness from the ratio of applied shear force and moment at the pile head (surface), where the stiffness increases with the ratio of pilehead moment to shear.

Given measurement from repeated loads on two piles and the incapability of the standard $p-y$ curves to predict the behaviour, Long \& Vanneste (1994) analysed 34 case stories for full-scale cyclic lateral load tests in sand. The case stories covered pile diameters ranging from $0.275 \mathrm{~m}$ to $1.43 \mathrm{~m}$, different installation methods and cyclic load conditions. Based on initial stiffness increasing linearly with depth a deterioration scheme was presented to calculate the cyclic $p-y$ curves based on number of cycles, cyclic load ratio, installation method and effect of soil density, with the cyclic load ratio as the primary factor. 


\subsubsection{Numerical modelling}

The influence on the initial stiffness from diameter was investigated by Sørensen et al. (2010), Lesny \& Wiemann (2006) by use of numerical modelling.

Sørensen et al. (2010) model piles with diameters of 1 to $7 \mathrm{~m}$ with an embedment length of $20 \mathrm{~m}$. The shear force was applied to the pile at some height above the soil surface and the relative density $\left(I_{d}\right)$ of the soil was varied between 0.13 and 0.8 . The initial stiffness of the $p-y$ curves was described by a function of depth, diameter and internal friction angle of the sand, where the combined expression shows a power dependency of each factor.

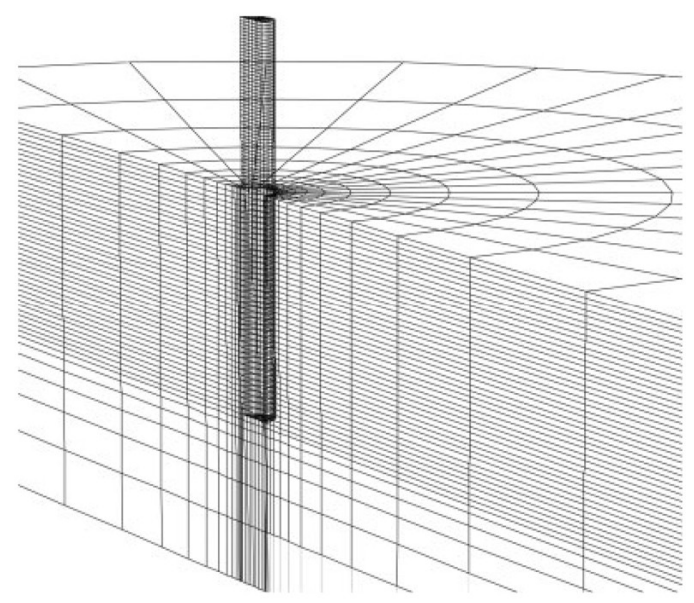

Figure 2.9 Numerical model (Sørensen et al. 2010).

The modified initial stiffness of the $p-y$ curves described by Sørensen et al. (2010) was for a location in the North Sea west of Denmark compared to both standard $p-y$ curve formulations (API 2007) and a numerical model, Augustesen et al. (2010). The analysed pile was in dense sand and had a diameter of $4 \mathrm{~m}$ and an embedment length of $22 \mathrm{~m}$. The conclusion was that the standard $p-y$ curves underestimates the stiffness at shallow depth and overestimates the stiffness at large depth, resulting in too stiff pile response. In addition the $p-y$ curves based on the modified initial stiffness was in reasonable concordance with the numerical model.

Lesny \& Wiemann (2006) analysed piles with a diameter of 1 to $6 \mathrm{~m}$ and embedment lengths of $10.6 \mathrm{~m}$ to $38.9 \mathrm{~m}$. The pile length had been chosen to fulfil a critical embedment length criteria to ensure a rigid fixation in the soil. The objective was to adjust the modulus of subgrade reaction to ensure a consistent stiffness with the critical embedment length criteria and the numerical model for large diameter piles. The analyses showed that a parabolic function fits the numerical model, and that the function is inversely proportional to the diameter.

Fan \& Long (2005) applied a 3D finite element program to investigate the soil response of laterally loaded pile in sand. The influence from pile properties, stiffness and diameter, initial horizontal stress on pile (coefficient of horizontal earth pressure) and soil dilatancy was investigated and the results were compared to existing methods for predicting ultimate capacity. The numerical analyses presented by Fan \& Long (2005) showed that the influence from the pile stiffness on the soil response was insignificant whereas the ultimate capacity had a non-linear dependency with pile diameter. In addition an increased initial horizontal stress gave increased initial stiffness and an apparent increase of ultimate capacity. The soil dilatancy had a significant influence on the soil capacity, with increasing capacity with increasing dilatancy. 
Achmus et al. (2007) describe the findings of a numerical study of static and cyclic loaded piles with diameters of $7.5 \mathrm{~m}$ and an embedment length of $30 \mathrm{~m}$ in dense or medium dense sand. The numerical model showed that the stiffness of a large diameter pile subjected to static loading was overestimated by use of the standard $p-y$ curves. In addition the analyses showed that the relative difference to the standard $p-y$ curves was independent of the height of the load above the groundline. Based on soil parameters obtained from cyclic triaxial tests an expression for the dependency of the oedometric stiffness modulus with number of cycles has been setup and applied to the numerical model. The results of the cyclic numerical models showed an increased displacement with increasing number of cycles, and a tendency that the rate of deformation decreases with increasing density of the sand and with decreasing load height above surface. Zania \& Hededal (2011) presented results of numerical investigations of a $\varnothing 2.0 \mathrm{~m}$ pile, in which the focus has been to quantify the effect of pile stiffness and pile-soil friction on the behaviour of the pile. The effect of the pile stiffness on ultimate capacity as well as the $p-y$ curves was found negligible, as long as the flexibility criteria for a rigid pile were met (criteria defined by e.g. Poulos \& Davis (1980)). As expected, an increasing interface shear strength increases the distance from the pile toe to the point of zero deflection. Furthermore, the stiffness of the $p-y$ curves increased.

The finite element analyses described by Zania \& Hededal (2011) showed in addition that the ultimate capacity increased with increasing pile-soil interface strength. The numerical analyses consistently showed higher capacities than predicted by the standard p-y curves. This may be attributed to the negligence of the contribution of side shear resistance to the ultimate capacity when applying the standard curves, and to the inappropriate variation of the normalized ultimate soil resistance with depth.

\subsubsection{Physical modelling}

Physical modelling in a centrifuge has been employed to investigate the behaviour of lateral loaded piles in sand. Barton et al. (1983) tested a pile with a prototype diameter of $0.635 \mathrm{~m}$ and an embedment length of $12.7 \mathrm{~m}$ located in very dense saturated sand. The main conclusion was that the standard $p-y$ curves underestimate the resistance at shallow depth and overestimate the resistance at great depth. In addition the initial stiffness is overestimated by use of the standard $p-y$ curves and the variation with depth seems to follow the square root of the depth.

Four static centrifuge tests piles in medium dense dry sand were analysed by Georgiadis et al. (1992). The diameter of the prototype piles was 1.1 to $1.2 \mathrm{~m}$ with a length of $9 \mathrm{~m}$. The load was applied $1.25 \mathrm{~m}$ above groundline. The conclusion was that the standard $p-y$ curves for dry sand underestimates the bending moment along pile and overestimates the stiffness of the soil. 
A series of static and cyclic lateral loaded tests have been carried out at LCPC Nante. Verdue et al. (2003) summarize the findings. The tested pile had a prototype diameter of $0.72 \mathrm{~m}$, an embedment length of $12 \mathrm{~m}$ and located in very dense dry sand. The load was applied $1.6 \mathrm{~m}$ above the soil surface and 50 load cycles were applied in each centrifuge test and at series of different load amplitudes were investigated. It was observed from the static tests that the lateral stiffness of the soil increases rapidly with depth

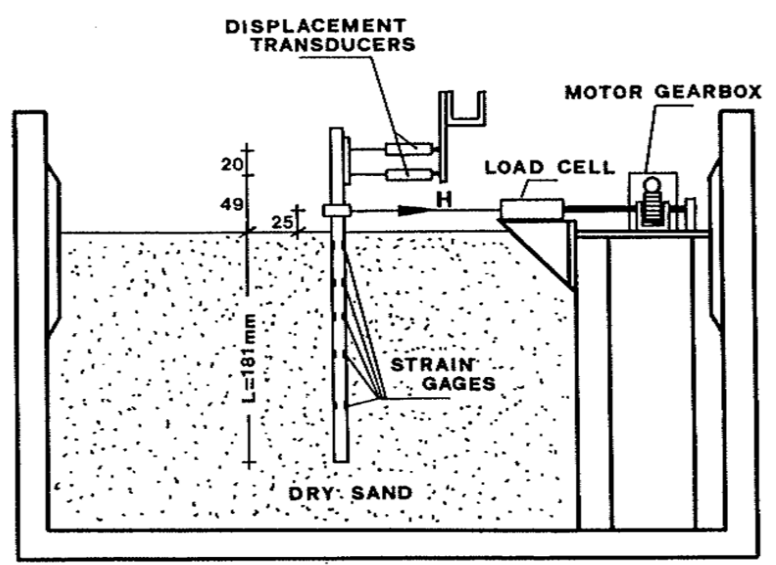

Figure 2.10 Physical model (Georgiadis et al. 1992). down to 4 times the diameter and much slower at larger depths. The secant stiffness at cyclic loading was 1.5 to 3 times the initial stiffness of the pile, and it increased with the number of cycles. The effect on the soil from cyclic loading was divided into two zones; an upper (less than $3.3 D$ ) in which the soil reaction decreases and the displacements increases with increasing number of cycles, and an lower where the $p-y$ curves during cyclic loading follows the virgin $p$ - $y$ curve with increasing displacements and soil resistance with increasing number of cycles.

Rosquöet et al (2007) investigated by use of centrifuge tests the behaviour of laterally loaded piles in dry sand subject to cyclic loading. The test piles had a prototype diameter of $0.72 \mathrm{~m}$, an embedment length of $12 \mathrm{~m}$ and were tested for dense to medium dense sand (a relative density of 0.53 and 0.86). The piles were expected to behave as flexible piles. The focus of the centrifuge tests was to investigate the effect of cyclic loading under service conditions, where the load was less than $1 / 3$ of the ultimate capacity. The main findings was that the influence on the pile head displacements from cyclic loading followed a power function of the relative load ratio and a logarithm function of number of cycles. The effect of cycles on the $p-y$ curve was concentrated on the first 15 cycles and that the effect from the cyclic loading on the soil stiffness varied with depth with either decrease or increase of the stiffness. A main observation was that the cyclic loading primary affected the upper $0-5 D$ of the soil layers.

Load transfer curves ( $p-y$ curves) for lateral loaded piles in calcareous sand has been investigated in centrifuge tests and reported by Dyson \& Randolph (1997), Dyson \& Randolph (1998) and Dyson $\&$ Randolph (2001). Due to inappropriate existing curves (estabileshed for silica sands) giving too stiff and too weak response the objective was to estabilsh experimental load transfer curves for fine grained calcareous sands, primary found at the North West Shelf of Austalia. It is noted that Calcareous sediments behave different compared with silica sands due to the high angularity of the particles and varying cementation (Dyson and Randolph 2001). The described investigations consisted of a series of centrifuge tests which included, open ended versus closed ended piles, 
different installation methods and different pile head conditions. A revised formulation of load transfer curves was estabiled based on instrumented test piles and the tests showed insignificant influence from open ended versus closed ended piles whereas some influence was observed from choice of installation method.

Li et al. (2010) carried out a series of force controlled one way cyclic lateral load tests on a pile with a prototype diameter of $3.1 \mathrm{~m}$ in very dense dry sand. The embedment length was $15.6 \mathrm{~m}$ and the load was applied approximately $42 \mathrm{~m}$ above the soil surface. When the load amplitude was below a threshold the accumulated permanent lateral displacements increases linear with the logarithm of the number of cycles and the incremental rate increases with increasing amplitude. When the load amplitude reaches the threshold the incremental rate also increases with the increasing number of cycles, indicating potential extensive displacements.

\subsubsection{Collation of research}

Comparison of the different approaches shows some discrepancy and conflicting statements. The main issue is if the discrepancy originates from opposing findings with the same basis or it is different elements of the pile-soil behaviour which are investigated. An apparent postulate is that the insitu measurements (Hald et al. 2009) relates to very small strains due to the dynamic nature of the measurements giving the initial stiffness of the $p-y$ curve where-as the findings from the numerical modelling for initial stiffness (Sørensen et al. 2010 and Lesny \& Wiemann 2006), are based on the fact that the $p-y$ curve formulation is correct and has the right shape from very small strains to large strains and thus fits their findings to this curve.

Caution should be applied in the interpretation of the in-situ tests as the properties of the soil are unknown primary due to the inadequate information on the present soil conditions. Available information originates from site investigations prior to construction and thus does not account for installation effects.

The differences between the different numerical models with either increasing or decreasing initial stiffness with diameter could be based on differences in the numerical modelling which is difficult to state exactly due to the complexity of the models in question.

Findings from the different approaches can be summarised as:

- The standard $p-y$ curves are inadequate to describe the behaviour of lateral loaded nonslender large diameter piles.

- Initial stiffness of the $p-y$ curves depends of the diameter, depth and soil strength, and increase of each these increases the stiffness. It is indicated that the initial stiffness of the $p$ $y$ curves has a parabolic / square root dependency with depth. 
- Cyclic response of a lateral loaded pile depends on the number of load cycles and the characteristics of the cyclic load, i.e. one-way; two-way; size of average and cyclic load component.

\subsection{Scope of research}

Behaviour of a monopile is a classic soil-structure interaction problem depending of the pile stiffness and the non-linear soil behaviour. The stress dependent and non-linear soil behaviour gives ground for application of physical models for understanding the general behaviour of the pile.

The main objective for the present research is:

Investigate the static and cyclic behaviour of large diameter rigid piles in sand by use of physical modelling and comparison of the findings with standard $p-y$ curves.

\subsubsection{Physical modelling}

Modelling is an important part of geotechnical engineering and research. The geotechnical engineer is by use of models able to investigate both the serviceability limit state and ultimate limit state in relation to the design process.

Physical modelling within the geotechnical field is among other things governed by complex stress dependent behaviour, especially in soil-structure interaction. This can be taken into account by using field monitoring of structures and full scale model tests. Full scale model tests have the advantage of the correct site conditions, soil properties and possibility to monitor the wanted elements/items. A disadvantage is that these tests can be extensive/expensive and are not always allowed to reach the ultimate limit state, with failure and/or large deformations. In addition it can be very difficult to differentiate between the different effects; non-homogeneous soil conditions, installation, etc. Full scale tests are usually not applicable to larger structures where magnitude prevents application of modelling and a smaller part is thus investigated.

The alternative to filed monitoring / full scale tests is use of small scale models where the proportions of the test are manageable. Small scale tests can either be carried out with normal stress levels in soil, i.e. soil is affected by gravity and due to limited soil volume relative low stress levels exist, or by an increased stress level either by applied overburden pressure or imposed gravity field. It is due to the stress dependent soil behaviour of interest to apply models with increased stress levels, to elaborate on the pile-soil behaviour and thus focus on small scale models with either applied overburden pressure or imposed gravity.

Small scale testing with overburden pressure is typical carried out in an pressure tank where a membrane separates the soil and the overburden (usually water under pressure) resulting in a 
relative uniform stress distribution in the soil. This method is compared to a modelled prototype different and numerical models are applied to transform observations to prototype scale.

The alternative small scale test with imposed gravity field is carried out with centrifuge modelling. The key element in centrifuge modelling is a soil sample in a model container placed at the end of a centrifuge arm rotating in a horizontal plane. The increased stress level is created by centripetal acceleration and enables modelling of stress dependent soil behaviour with soil-structure interaction in small samples with increasing stress. The use of centrifuge models challenges the physical setup of the model as the setup is rotating, and the physical fact that the centripetal acceleration (radial acceleration) increases with distance to rotational axis, hence the gravity increases through the applied model.

With main interest for investigation the behaviour of piles in sand and the possibility to use the centrifuge facilities at Danish Technical University (DTU) the focus on use of physical models is set on centrifuge modelling. DTU operates the sole geotechnical centrifuge in Scandinavia.

\subsubsection{Centrifuge modelling}

In centrifuge modelling the test setup with soil sample is rotated in a horizontal plane. The rotation creates a radial acceleration field in which the acceleration in a specified point is given by the angular rotation speed $(\omega)$ and the distance $(r)$ from the rotational axis, see Figure 2.11 .

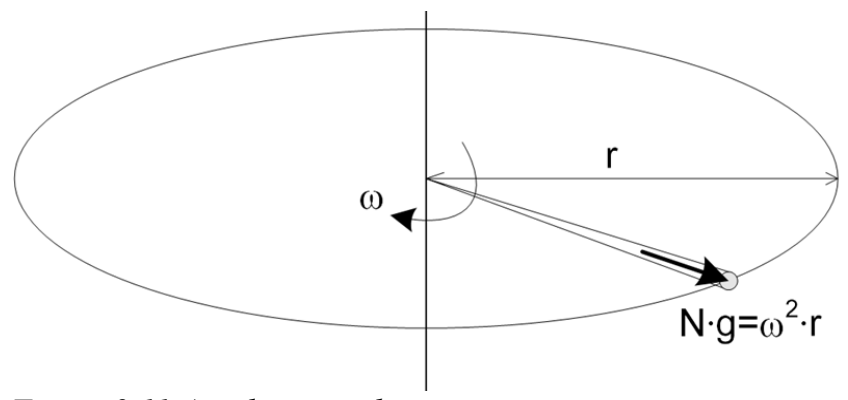

Figure 2.11 Acceleration due to rotation.

The radial acceleration $a_{r}$ in the centrifuge compared to the acceleration of gravity $g$ gives the scaling factor $N$ :

$$
\begin{aligned}
& a_{r}=N \cdot g=r \cdot \omega^{2} \\
& N=\frac{r \cdot \omega^{2}}{g}
\end{aligned}
$$

Where $r$ is the radius to the point considered and $\omega$ is the angular velocity in radians per second. 
The gravity scale factor varies linearly with distance from the rotation axis, and with the square of angular rotation speed, see Figure 2.11. The rotation speed is usually kept constant during centrifuge tests, which leads to a small difference between the stress increase with depth in model and prototype, see Figure 2.12.

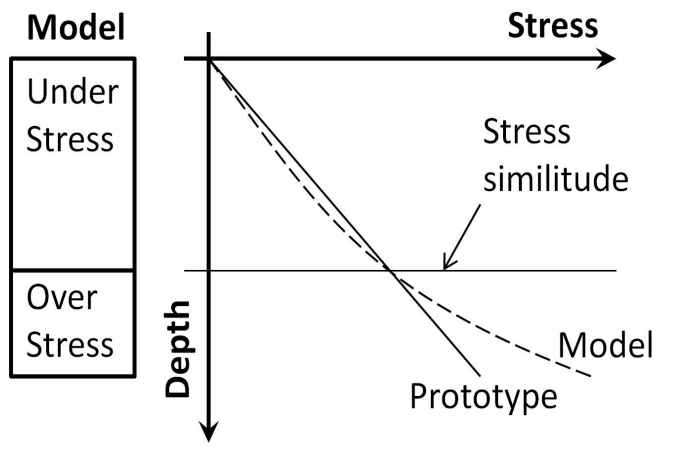

Figure 2.12 Comparison of vertical stress variation in centrifuge model and corresponding prototype.

A choice of reference level to $1 / 3$ of model height will minimize the relative error between the model and prototype, which for the majority of geotechnical centrifuges will be less than $3 \%$, Taylor (1995).

More explicitly, the error on the stress level is less that $2.3 \%$ of the prototype stress for a model height of $0.3 \mathrm{~m}$ and a distance from top of the model to the rotational axis of $2.1 \mathrm{~m}$, which is equivalent to the model in the present research, see Chapter 3.

The scale factors listed in Table 2.1 can be determined by use of scaling laws. Scaling of time depends on the problem investigated. Diffusion problems (seepage), dynamic problems (inertia) and viscosity problems are not scaled in the same way and it is necessary to consider the mechanisms modelled. The issue is considered in Taylor (1995), Fuglsang \& Ovesen (1988) and Garnier et al. (2007).

Table 2.1 Scale factors

\begin{tabular}{|c|c|c|c|}
\hline \multicolumn{2}{|c|}{ Parameter } & Unit & Scale (model/prototype) \\
\hline \multicolumn{2}{|c|}{ Acceleration } & $\mathrm{m} / \mathrm{s}^{2}$ & $\mathrm{~N}$ \\
\hline \multicolumn{2}{|c|}{ Linear dimension } & $\mathrm{m}$ & $1 / \mathrm{N}$ \\
\hline \multicolumn{2}{|l|}{ Stress } & $\mathrm{kPa}$ & 1 \\
\hline \multicolumn{2}{|l|}{ Strain } & - & 1 \\
\hline \multicolumn{2}{|c|}{ Density } & $\mathrm{kg} / \mathrm{m}^{3}$ & 1 \\
\hline \multicolumn{2}{|c|}{ Mass or Volume } & $\mathrm{kg}$ or $\mathrm{m}^{3}$ & $1 / \mathrm{N}^{3}$ \\
\hline \multicolumn{2}{|c|}{ Unit weight } & $\mathrm{N} / \mathrm{m}^{3}$ & $\mathrm{~N}$ \\
\hline \multicolumn{2}{|l|}{ Force } & $\mathrm{N}$ & $1 / \mathrm{N}^{2}$ \\
\hline \multicolumn{2}{|c|}{ Bending moment } & $\mathrm{Nm}$ & $1 / \mathrm{N}^{3}$ \\
\hline \multicolumn{2}{|c|}{ Bending moment / unit width } & $\mathrm{Nm} / \mathrm{m}$ & $1 / \mathrm{N}^{2}$ \\
\hline \multicolumn{2}{|c|}{ Flexural stiffness / unit width (EI/m) } & $\mathrm{Nm}^{2} / \mathrm{m}$ & $1 / \mathrm{N}^{3}$ \\
\hline \multirow[t]{3}{*}{ Time: } & Diffusion & $\mathrm{s}$ & $\mathrm{N}^{2}$ \\
\hline & Inertia & $\mathrm{s}$ & $\mathrm{N}$ \\
\hline & Viscous & $\mathrm{s}$ & 1 \\
\hline
\end{tabular}


The dynamic element is scaled by $\mathrm{N}$ while the seepage part follows $\mathrm{N}$ squared. This issue is usually approached by changing the flow properties of the soil. With grain size and hydraulic conductivity is kept constant, the use of pore fluid with a higher viscosity will ensure a proper scaling of the flow, Taylor (1995).

If all the linear dimensions in the model should be scaled with the same scale factor, then the grain size should be scaled as well. A change in grain size will with respect to stresses in the soil tend to change the properties of the material in question. It is thus of interest to use the original material, and instead focus on the influence from the particle size on the studied mechanisms. The catalogue of scaling laws by Garnier et al. (2007), refers research indicating that no significant grain size effect is detected when the relation between average grain size $\left(d_{50}\right)$ and pile diameter $(D)$ fulfils:

$$
\frac{D}{d_{50}}>45 \dot{a} 60
$$

In addition to the effects described, boundary effects and physical dimensions need attention. The fact that the test must be controlled remotely needs to be considered, as the entire setup is in motion and thus not accessible during the test.
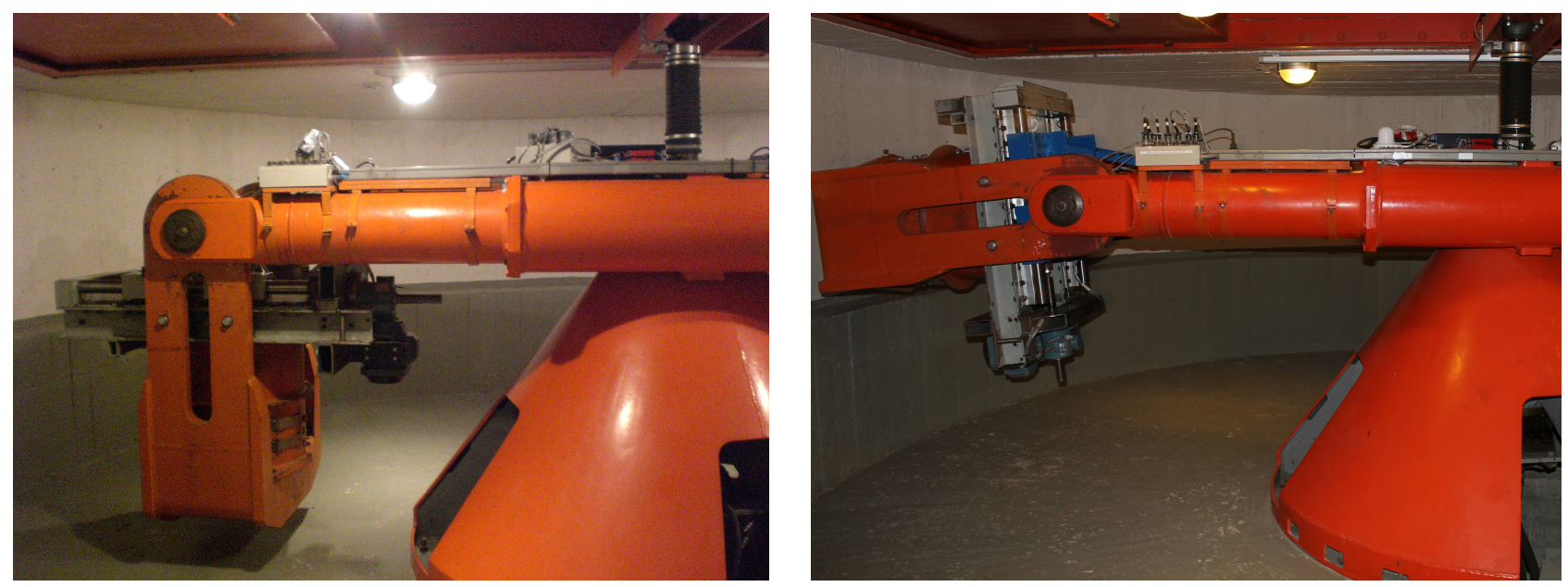

Figure 2.13 Centrifuge at DTU, left: At rest, Right: In action 


\subsubsection{Condensed scope}

It became evident in the initial phase of the research that the centrifuge facilities at Danish Technical University (DTU) was outdated and that the focus should be changed to establish up-todate centrifuge facilities for medium to large diameter piles, and to initiate the research on the behaviour of large diameter piles in sand under static and cyclic loading.

Centrifuge tests on laterally loaded piles in sand involves a series of different elements which each needs to be addressed:

- Equipment for controlling centrifuge tests and data acquisition.

- Preparation of sand sample.

- Knowledge on general soil properties.

- Verification of preparation.

- Installation of pile.

- Equipment for lateral load tests and calibration.

The preparation of sand sample is a practical issue, where the applied method of placing the sand in the test container must be considered and verified, along with the choice of testing wet or dry sand. Choice of saturation influences the applied method and how the soil is handled between tests. The use of saturated soil and the related issues regarding scaling laws and flow were considered in the initial phase of the research and it was decided to omit saturated soil from the present research and focus on use of dry sand and preparation of dry samples.

Early work on the effects from installation on the behaviour of laterally loaded piles in sand was presented by Craig (1984) who described results from centrifuge tests with $\varnothing 19.05 \mathrm{~mm}$ piles installed (jacked) at $1 \mathrm{~g}$ and $52.5 \mathrm{~g}$. The tests reported by Craig (1984) revealed that the lateral response of piles was stiffer when installation is carried out at higher stress levels. The pile head stiffness is approximate $25 \%$ less when installed at $1 \mathrm{~g}$, when compared at a pile head displacement equal to $10 \%$ of the diameter.

The effect from installation and open-ended nature of offshore piles in calcareous sands was investigated in centrifuge tests by Dyson \& Randolph (1998) and Dyson \& Randolph (2001). Calcareous sediments behave different compared with silica sands due to the high angularity of the particles and varying cementation (Dyson \& Randolph 2001). The reported test series compromised 4 different installation methods and open-ended versus closed-ended model piles. The model pile diameter was $13 \mathrm{~mm}$ and the tests were carried out at $160 \mathrm{~g}$. The 4 tested installation methods were: Pre-installation, jacked at $1 \mathrm{~g}$ and $160 \mathrm{~g}$ and driven at $160 \mathrm{~g}$. 
Dyson \& Randolph (1998) and Dyson \& Randolph (2001) analysed the obtained load-transfer curves and pile head response and the tests showed significant influence on the pile stiffness, with the stiffest response from the driven piles and the softest response from the pre-installed piles. The pile head stiffness, compared to the driven pile, was for pre-installed and jacked at $1 \mathrm{~g}$ and $160 \mathrm{~g}$, respectively $60 \%, 77 \%$ and $83 \%$ (compared at a pile head displacement equal to $20 \%$ of the diameter). An analysis of the load-transfer curves revealed that the influence from installation method decreases with depth and is almost negligible at a depth of 5 times the diameter. The analyses suggested that the void ratio immediately around the pile is affected by the installation:

- Pre-installation gives no disturbance

- Jacked at $1 \mathrm{~g}$ gives cavity expansion and some dilation which would cause a heave at the surface

- Jacked at $160 \mathrm{~g}$ gives an increased stress level reducing the dilation

- Driven at $160 \mathrm{~g}$ where the stress level reduces dilation and is combined with cyclic loading and vibration.

Long \& Vanneste (1994) and Lin \& Liao (1999), have included the effect from installation method in the prediction of effects from cyclic lateral loads on piles in sand. Cyclic field load tests are analysed in the two articles and equations are derived to describe the development of strain/displacements during cyclic loading of single pile in sand. Long \& Vanneste (1994) ends with a modification of p-y curves. Lin \& Liao (1999) relate the displacement during cyclic loading to a strain figure and derive a set of equations describing the change in strain during cyclic loading. Both methods use a factor for "effect of soil density", "effect of pile installation method" and "effect of cyclic load ratio". It is not possible to quantify the influence from the installation method on the initial pile stiffness. The articles indicate that the effect of subsequent load cycles vary depending on the installation method, with the largest change in stiffness from a drilled pile and the smallest change for vibrated pile.

The main conclusion is that it is preferable to apply inflight installation, and Dyson \& Randolph (1998) and Dyson \& Randolph (2001) show a tendency of obtaining a stiffer response for inflight installation compared to installation at $1 \mathrm{~g}$. The work by Dyson \& Randolph (2001), shows in addition that the influence decreases with depth. Investigation of the installation effect involves development of centrifuge equipment for inflight installation in addition to what is needed for the preparation of samples and subsequent lateral load tests. It was due to the general extensive task of obtaining updated facilities decided to omit the installation effects from the current research and apply installation at $1 \mathrm{~g}$. 
The key point in the development of the equipment for the lateral loading was to base it on existing equipment and establish an updated setup usable for large-diameter piles with varying diameter and applied with either static or cyclic loading.

Following issues are of primary concern in the research on the behaviour of laterally loaded large diameter stiff piles in dry sand:

- General behaviour of monopile subject to lateral loading (static / cyclic).

- Initial stiffness of soil response.

- Ultimate capacity of laterally loaded pile.

- Accumulation mechanisms from cyclic loading.

- Change in pile stiffness response during cyclic loading. 



\section{Experimental testing}

\subsection{Introduction to centrifuge testing - practical issues}

With reference to Figure 3.1 the principle components of a geotechnical beam centrifuge are:

- Main centrifuge engine with driving shaft for rotation of centrifuge.

- Rotating beam.

- Two swing platforms (cradle) mounted on the beam.

- One platform for test setup consisting of prepared soil sample in reinforced container and mounted test equipment.

- One platform with counter weights to ensure horizontal beam balance.

- Slip ring stack for electric connection to the equipment on the beam.

- Controls for the centrifuge engine.

- Test controls and data logging.

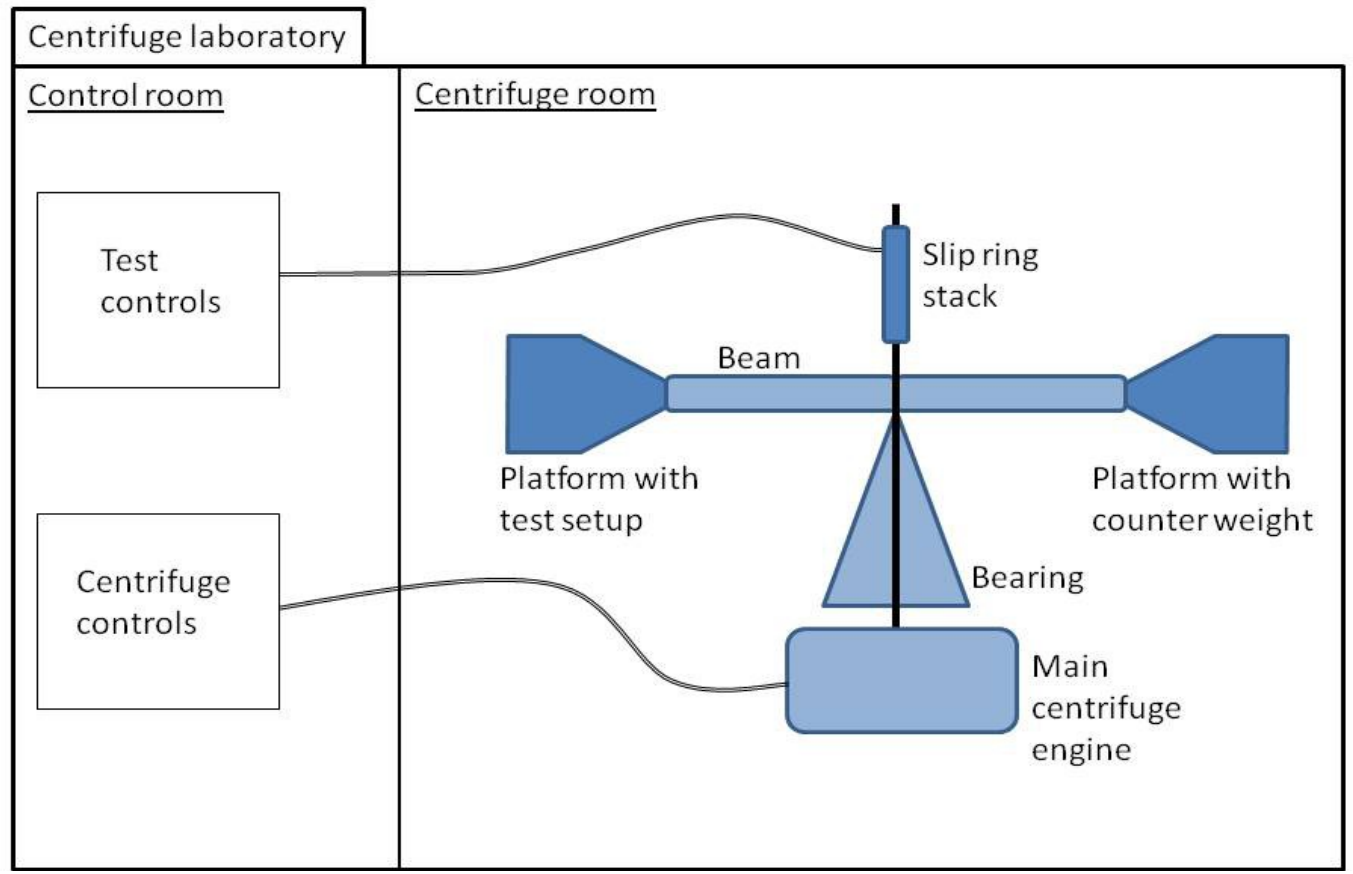

Figure 3.1 Principle components of a geotechnical centrifuge.

The scope, cf. section 2.4.3, of the present research has been to update the outdated facilities and initiate research on laterally loaded large diameter piles in dry sand. The research is narrowed to piles with a equivalent prototype diameter of 1-3 $\mathrm{m}$ and an embedment length of 10 times the 
diameter. The following sections describe the work carried out with respect to the practical issues related to the update and the test scheme for the research. The results from the static and cyclic tests carried out are presented and discussed in chapter 4 and 5.

\subsection{Centrifuge facilities}

The laboratory housing the geotechnical beam centrifuge at Danish Technical University (DTU) was build in 1976. The control room and the workshop is on the ground floor and the centrifuge is in the basement, accessible through a hatch. A cross section of laboratory building is shown in Figure 3.2. A major upgrade of the test control system was in 1998 founded by the Corrit Foundation.

The main centrifuge arm is $1.7 \mathrm{~m}$, measured from the rotational axis to the hinge where the swing platform is attached. The distance to the platform base is $2.63 \mathrm{~m}$ measured from the axis. The centrifuge is driven by a hydraulic engine located at the base of the centrifuge.

The DTU centrifuge has a capacity of 100 g-ton and can provide a gravitational acceleration of $75-85 \mathrm{~g}$. A maximum of $450 \mathrm{~kg}$ soil sample and test setup can be applied on the platform.

Tests can be carried out on soil samples prepared

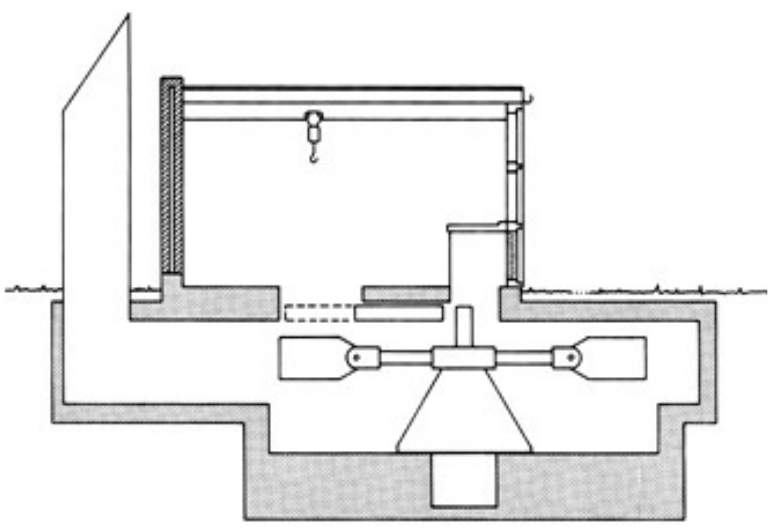

Figure 3.2 Cross section of centrifuge laboratory at DTU.

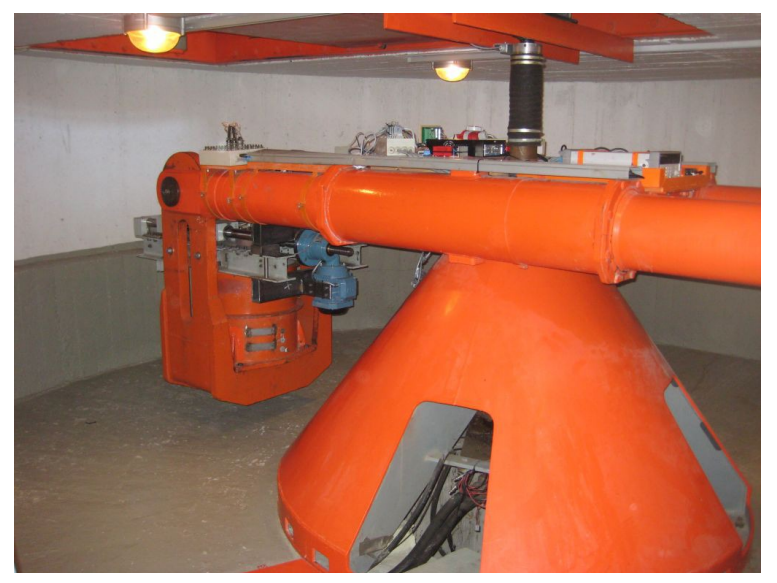

Figure 3.3 Centrifuge at DTU - swing platform with test setup is to the left. in either a circular or rectangular container. The possible modelled prototype soil volume is with a scale factor of 80 (increased gravitational acceleration) for the circular container $42 \times 39 \mathrm{~m}$ $($ diameter $\times$ height $)$ and for the rectangular container $56 \times 40 \times 56 \mathrm{~m}$ (length $\times$ width $\times$ height).

A further description of the centrifuge is given in Fuglsang (1977) and Leth (2011).

The wear and tear have over the years affected the main centrifuge machine, and laboratory building, and it has been necessary to replace the main power supply to the laboratory (due electrical short circuit), renovate the hydraulic engine (large oil leak) and mending of cracks in the masonry of the building. 
The test control system introduced in the 1998 upgrade consisted among other things of a desktop $\mathrm{PC}$ in the control room and a data logger placed on the centrifuge. The logger and the PC were connected through a set of HP Extenders where the low voltage analogue signal from the extender on the centrifuge arm has been transferred through the slip rings to the extender in the control room. Measurements from tests have been carried out by either the data logger on the centrifuge or a direct measurement (low voltage) from the control room via the slip rings, wires and a soldering terminal in the control room. Any control signals to a given test setup have been transferred as the approach with direct measurements, i.e. to the soldering terminal, by wires to the slip rings and further to the equipment.

The available setup, advanced when established in 1998, has not been up to date when the present research was initiated, and had in addition to being inflexible some issues with transfer of low voltage signals for the control systems.

It has after some research and discussions with skilled laboratory technicians been decided to replace the test controls and the data acquisition system with a system based on a flight PC placed on the centrifuge arm. The new concept is that all the data acquisition and control signals are handled on the centrifuge arm, without unnecessary conversion and transfer. Introduction of a flight pc entailed the use of a standardized programming tool for control of the various test systems. The flight PC is accessible through a wireless network in the centrifuge room. The updated system is illustrated in Figure 3.4 and further description of the components can be found in Leth (2011).

\section{Control Room | Centrifuge}

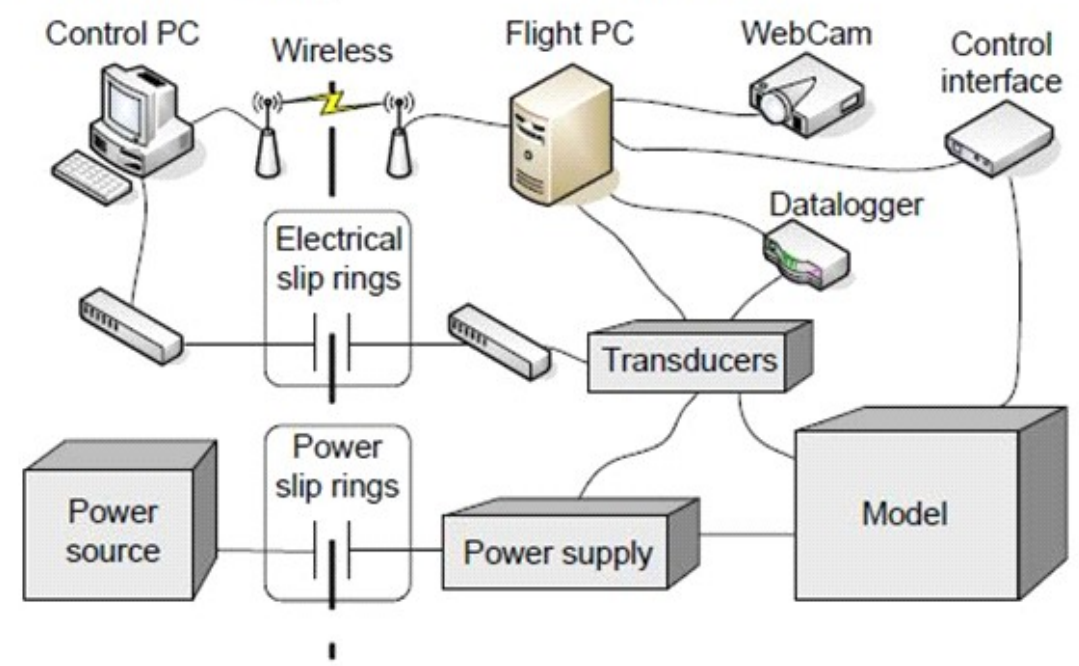

Figure 3.4 Schematic view of the new centrifuge control and data acquisition system. 
Application of the new control and acquisition system based on a flight PC has been a success. The various components have been gathered on the centrifuge arm, upgraded and the compiled system is flexible so future developments with respect to monitoring and test control can be included without extensive restructuring of the setup. The setup has, with respect to the data acquisition, been improved with the possibility to obtain high frequency sampling directly to the fligth PC.

\subsection{Laboratory sand and sample preparation}

\subsubsection{Laboratory sand}

In section 2.4.2 reference has been made to research on scale effects with respect to pile diameter $(D)$ and average grain size $\left(d_{50}\right)$. The listed requirements was a ratio $\left(D / d_{50}\right)$ of above 45 á 60 . It is thus necessary to apply a relative fine sand and it is chosen at DTU to use Fontainebleau Sand in the centrifuge tests.
Table 3.1 Classification parameters for Fontainebleau sand.

\begin{tabular}{|l|l|l|}
\hline Specific gravity of particles & $\mathrm{d}_{\mathrm{s}}$ & 2.646 \\
\hline Minimum void ratio & $\mathrm{e}_{\min }$ & 0.548 \\
\hline Maximum void ratio & $\mathrm{e}_{\max }$ & 0.859 \\
\hline Average grain size & $\mathrm{d}_{50}$ & $0.18 \mathrm{~mm}$ \\
\hline Uniformity index & $\mathrm{U}$ & 1.6 \\
\hline
\end{tabular}

The Fontainebleau Sand is a natural uniform silica sand from the region of Etampes south of Paris in France. The silica sand consists of fine rounded particles, and the classification parameters for the sand are listed in Table 3.1.

A series of static triaxial tests have for the present study been carried out on the Fontainebleau sand applied in the centrifuge tests. The triaxial tests have all been made on dry sand with a void ratio of 0.599 , equal to a relative density $\left(I_{d}\right)$ of 0.837 or dry unit weight of $16.2 \mathrm{kN} / \mathrm{m}^{3}$. The confining pressure was in the range of 30-300 $\mathrm{kPa}$ representing the stress level in the centrifuge tests. Leth (2011) contains additional information on the Fontainebleau sand including the results from the triaxial tests. The main results derived from the tests are plotted in Figure 3.5.

The failure criterion determined by the triaxial tests is in the $q-\sigma_{3}^{\prime}$ and the $p^{\prime}-q$ stress space described by:

$$
\begin{aligned}
& \sigma^{\prime}{ }_{3}=0.142 \cdot q^{1.129} \\
& q=2.16 \cdot p^{\prime 0.94}
\end{aligned}
$$

Where $\sigma_{1}^{\prime}$ and $\sigma_{3}^{\prime}$ is the effective major and minor principal stress in $\mathrm{kPa}, q=\sigma^{\prime}{ }_{1}-\sigma^{\prime}{ }_{3}$ and $p^{\prime}=\frac{1}{3}\left(\sigma^{\prime}{ }_{1}+2 \cdot \sigma^{\prime}{ }_{3}\right)$. 
The tangent friction angle for a void ratio of 0.599 is described by:

$$
\varphi=36.7^{0}-1.93^{0} \cdot \ln \left(\frac{\sigma^{\prime}}{p_{a}}\right)
$$

Where $p_{a}$ is equal to $100 \mathrm{kPa}$.

A relation between change of friction angle and a change in void ratio, $\Delta e$, has been determined as:

$$
\Delta \tan (\varphi)=-1.75 \Delta e
$$

A variation in relative density of $\pm 10 \%$ will give a variation in friction angle of 2.6 degrees. This results in a requirement of a method for repeatable preparation of homogeneous samples for testing in the centrifuge.

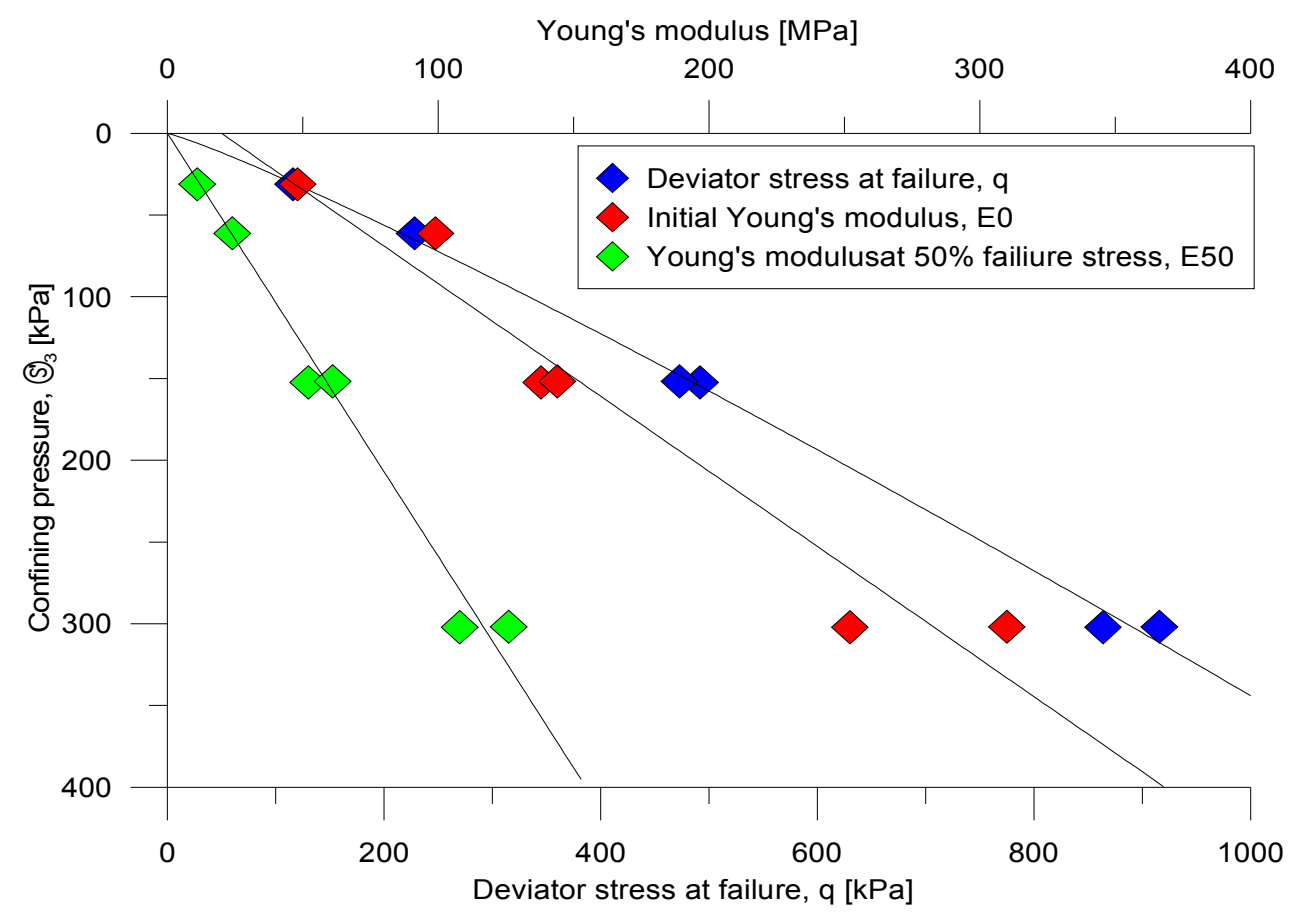

Figure 3.5 Main results from triaxial tests on Fontainebleau sand, $I_{d}=0.837$. 


\subsubsection{Preparation of sand sample}

A very important basis for model testing is preparation of a homogeneous soil sample with known properties, which by a standardized preparation method can be reproduced for large series of model tests.

It has been chosen to apply the spot pouring method for preparation of soil samples, and a spot pouring hopper (SPH) has build at the centrifuge facilities at DTU. The SPH is outlined in Figure 3.6 and the main components are:

- Elevated container for storage of the sand. The elevation height can continuously be adjusted.

- Valve that controls the sand flow from the container.

- Flexible tube to ensure horizontal movement of the muzzle.

- Muzzle with guide. The muzzle configuration controls flow rate of the sand into the sample container.

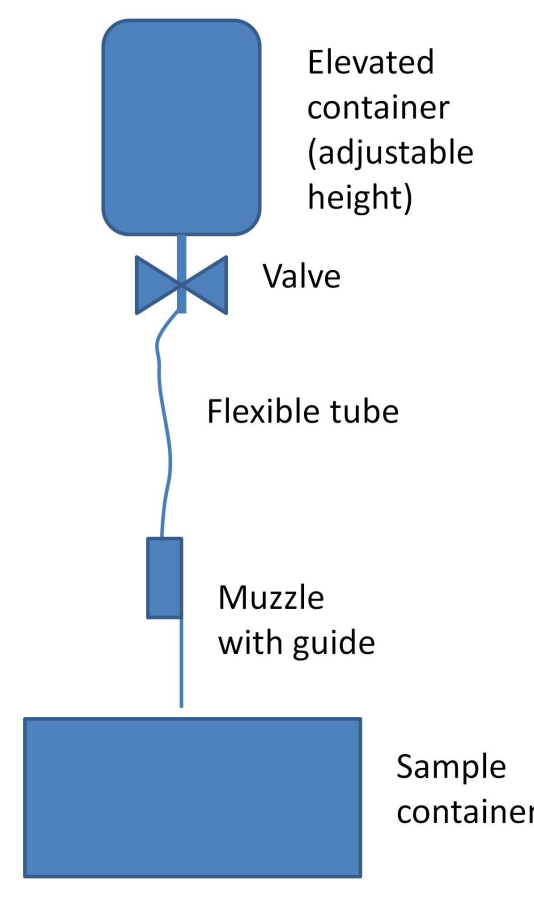

Figure 3.6 Outline of spot pouring hopper (SPH).

The basics of the SPH is that the density of a prepared sample is controlled by variation of drop height and flow rate (muzzle). Decreasing flow rate and increasing drop height increases the density, where the major influence is from changes in flow (Chen et al. 1998 and Zhao et al. 2006). The muzzle is by the user moved back and forth over the container in a consistent pattern to ensure full coverage. The influence on the density from the applied pattern is expected to be very small, less than $1 \%$ according to Chen et al. (1998).

It is noted by Zhao et al. (2006) that the shape of the sample container has an influence on the obtained density, and thus makes it necessary to perform calibration/initial tests on a container similar to the container used in the tests to determine the obtainable density. The overall procedure applied to prepare the sample will influence the obtained density and repeatability, hence a degree of user dependency is expected with the use of the SPH. 
The present SPH equipment at DTU has following properties:

- Container with a volume of 200 litres for storage of sand.

- $\varnothing 100 \mathrm{~mm}$ valve that controls the sand flow from the storage container.

- Flexible tube with a length of $100 \mathrm{~cm}$. The flexible tube is connected to a funnel located below the control valve.

- Muzzle consisting of orifice plate and sieves.

- Drop height of up to $70 \mathrm{~cm}$. A simple wire guide is used to verify the drop height.

The equipment is shown on the pictures below, Figure 3.7 to Figure 3.10.

Components of the muzzle are shown in Figure 3.11, where as the assembled muzzle is sketched in Figure 3.12. The main parts of the muzzle are the orifice plate and the sieves. The orifice plate has a central hole, which directly controls the flow rate through the muzzle, i.e. increasing diameter gives increasing rate. The main function of the sieves is to smooth the flow to avoid a concentrated jet, that disturbs the prepared sample. Further description of the preparation equipment and methods is given in Leth (2011).

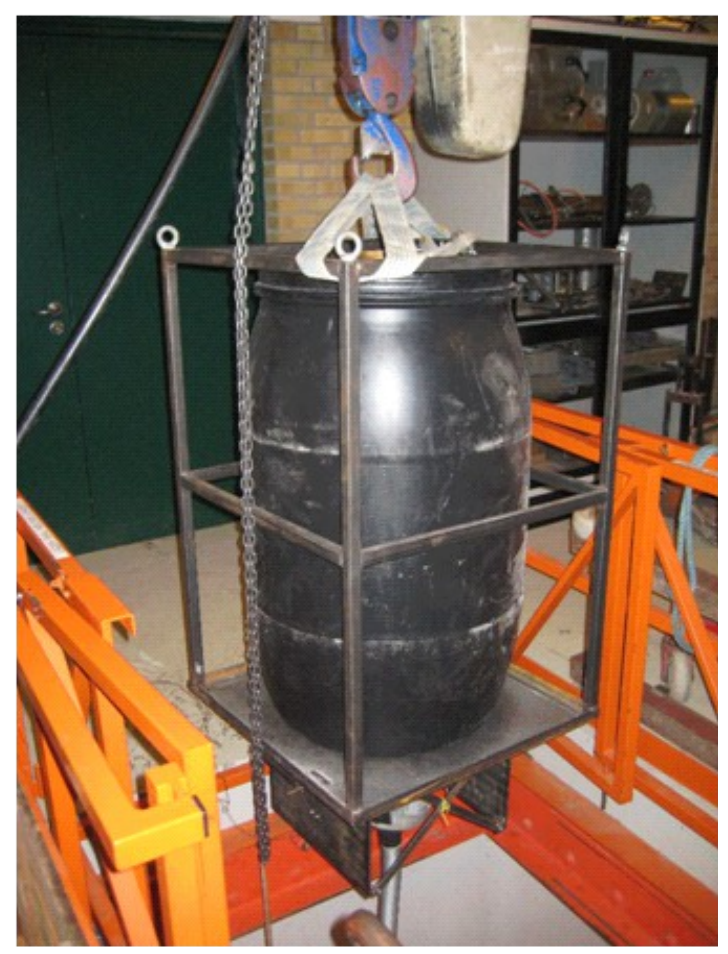

Figure 3.7 Storage container.

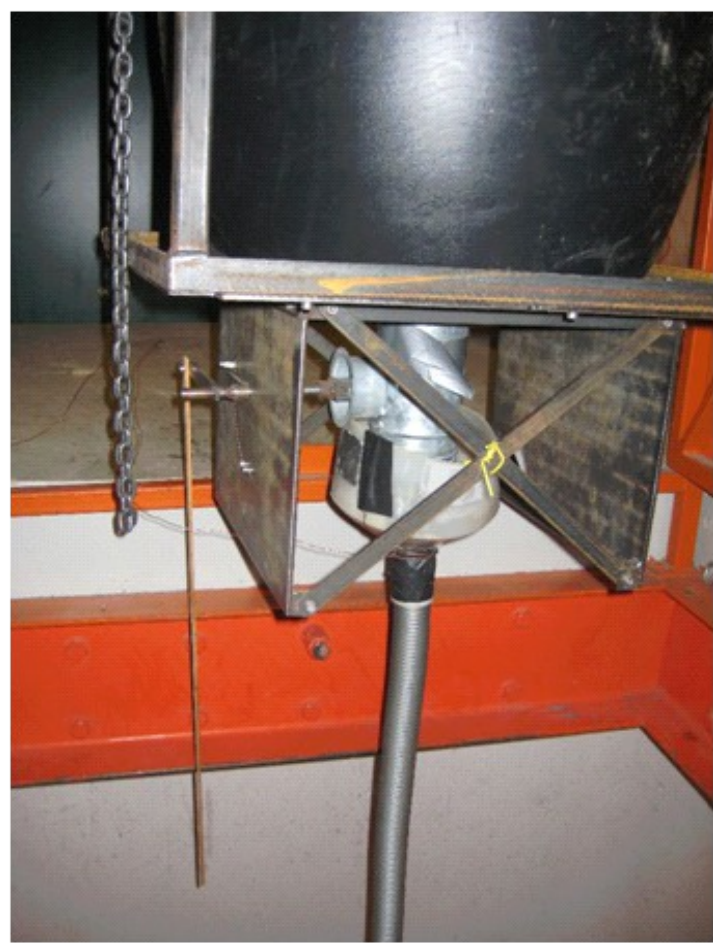

Figure 3.8 Control valve and flexible tube. 


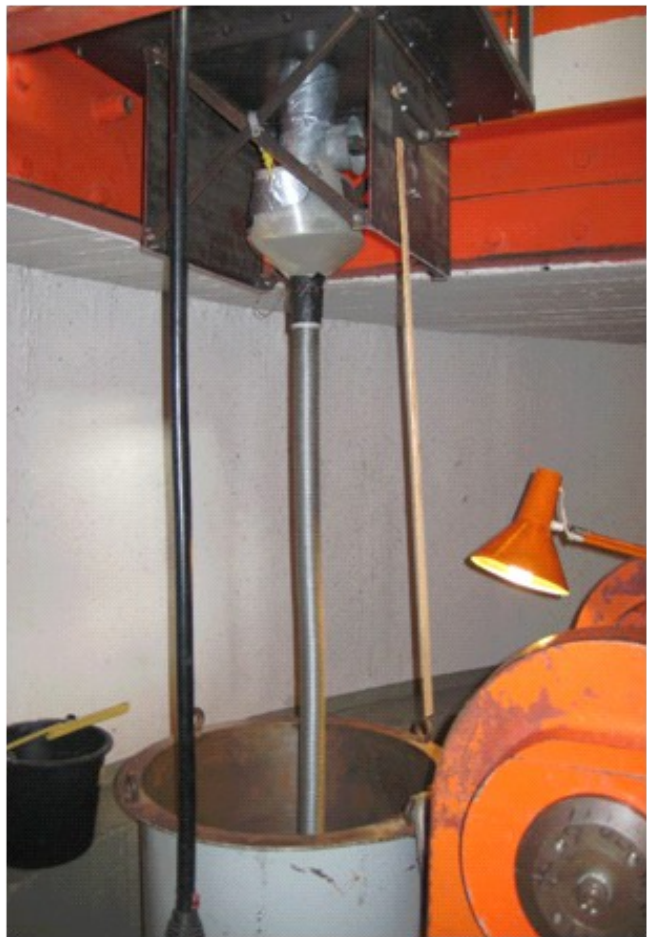

Figure 3.9 SPH setup.

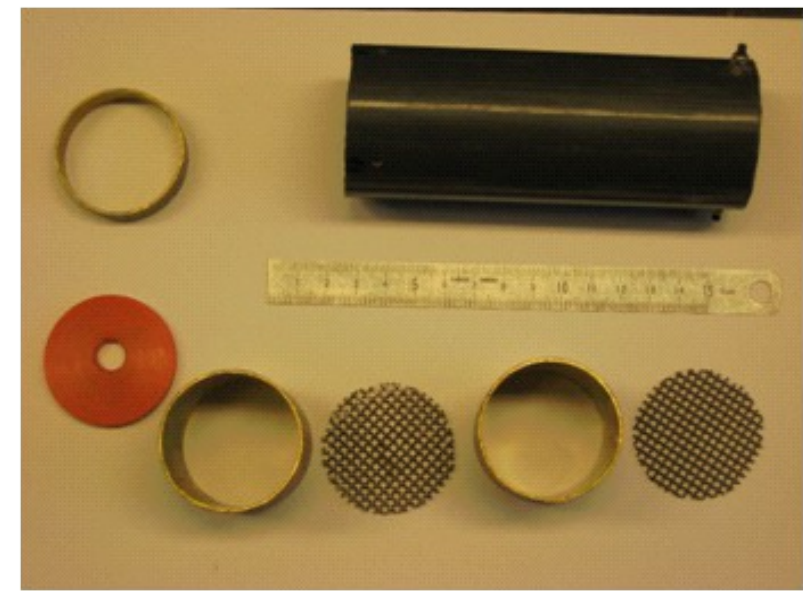

Figure 3.11 Muzzle components.

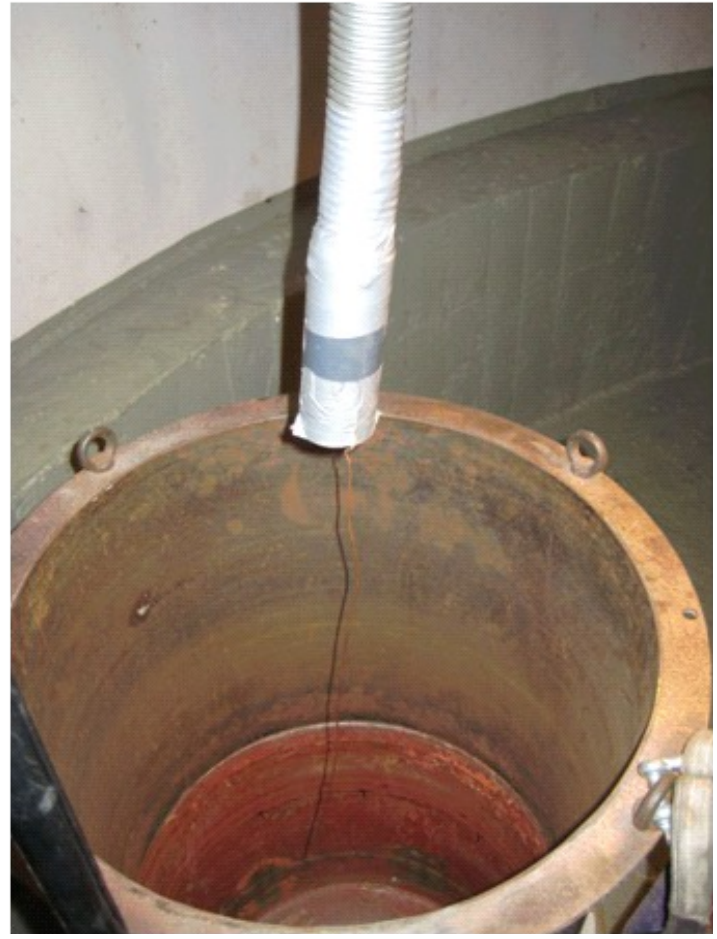

Figure 3.10 Muzzle with wire guide.

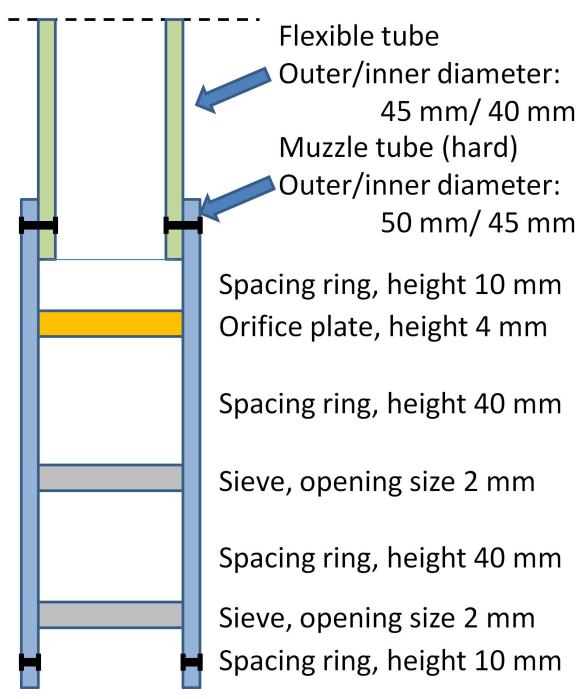

Figure 3.12 Outline of assembled muzzle.

The constructed SPH has been used to prepare 32 samples, of which 7 have been used to investigate the influence fromflow rate and drop height on the density of the prepared samples while 25 have been for the lateral loaded pile tests.

It has been possible to obtain a relative density between 0.37 and 0.88 by varying the drop height from 10 to $50 \mathrm{~cm}$ and the hole in the orifice plate from 8 to $24 \mathrm{~mm}$. 
The reproducibility can be assessed from the 25 samples prepared for the load tests, and the obtained relative densities are presented in Figure 3.13. An average relative density of 0.842 has been obtained with a sample variation of 0.0007 . All but two of the prepared samples are within $\pm 5 \%$ of the average relative density. The homogeneity of the sample is considered in the next section.

The SPH setup can be applied to prepare sand samples with a wide range of relative densities and it is possible by use a standardized preparation method to reproduce a specific relative density within $\pm 5 \%$ of the target value.

The flow rate controls the density, lower flow giving higher density. Preparation of approximate 180 $\mathrm{kg}$ of sample with an orifice plate with a $10 \mathrm{~mm}$ hole takes approximate $2 \mathrm{hrs}$. and gives a relative density of $0.85-0.90$. Time taken to prepare sample can be shortened by modification of tube and muzzle - increase diameter of muzzle with an orifice plate with multiple holes.

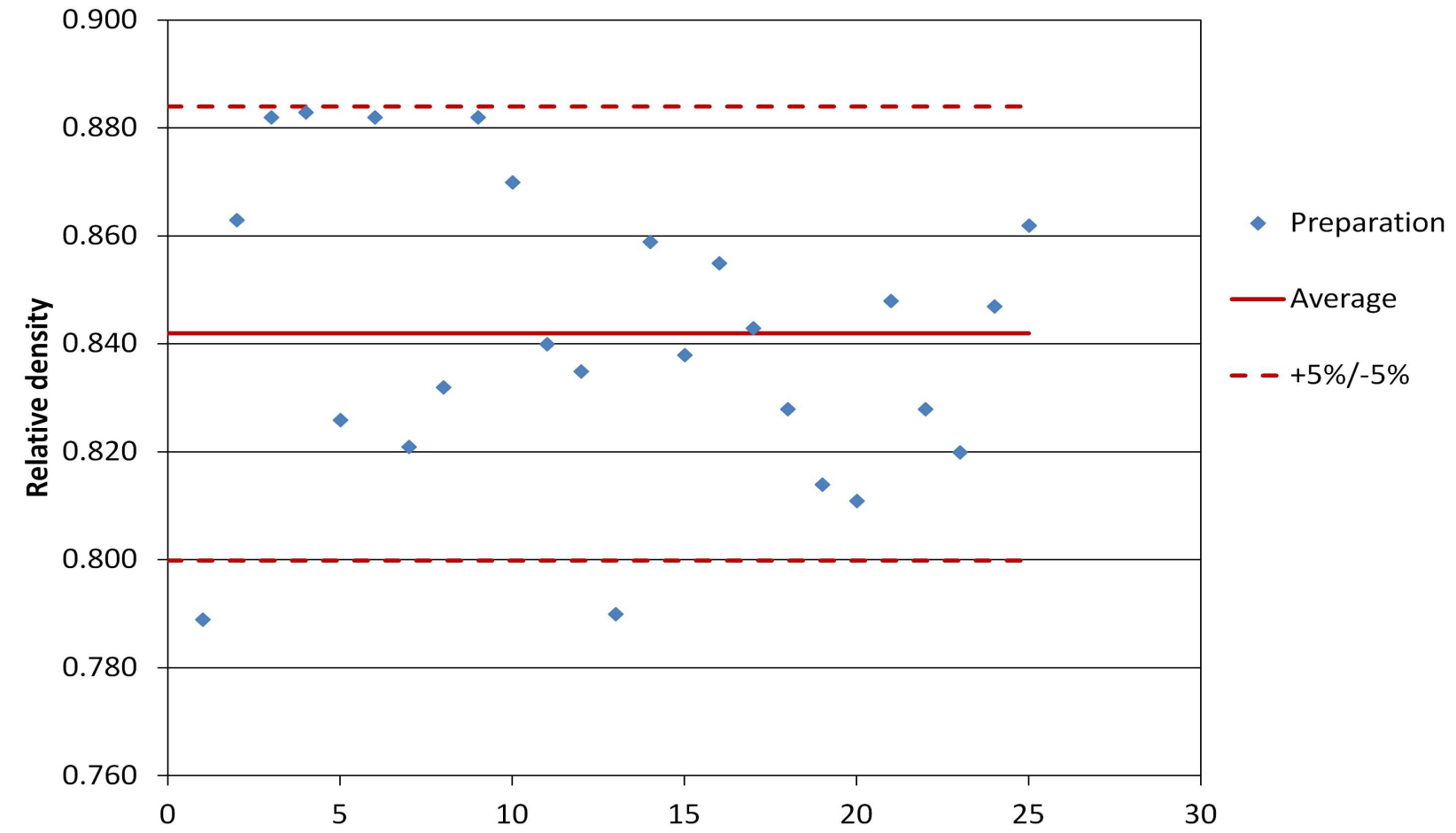

Figure $3.13 \quad$ Plot of obtained relative densities in prepared samples. 


\subsubsection{Validation of sample homogeneity - cone penetration tests}

Cone Penetration Testing (CPT) can be carried out in the centrifuge for tests with a circular container. The setup consists of a penetrometer frame and a penetrometer. Figure 3.14 shows the CPT setup mounted on the centrifuge.

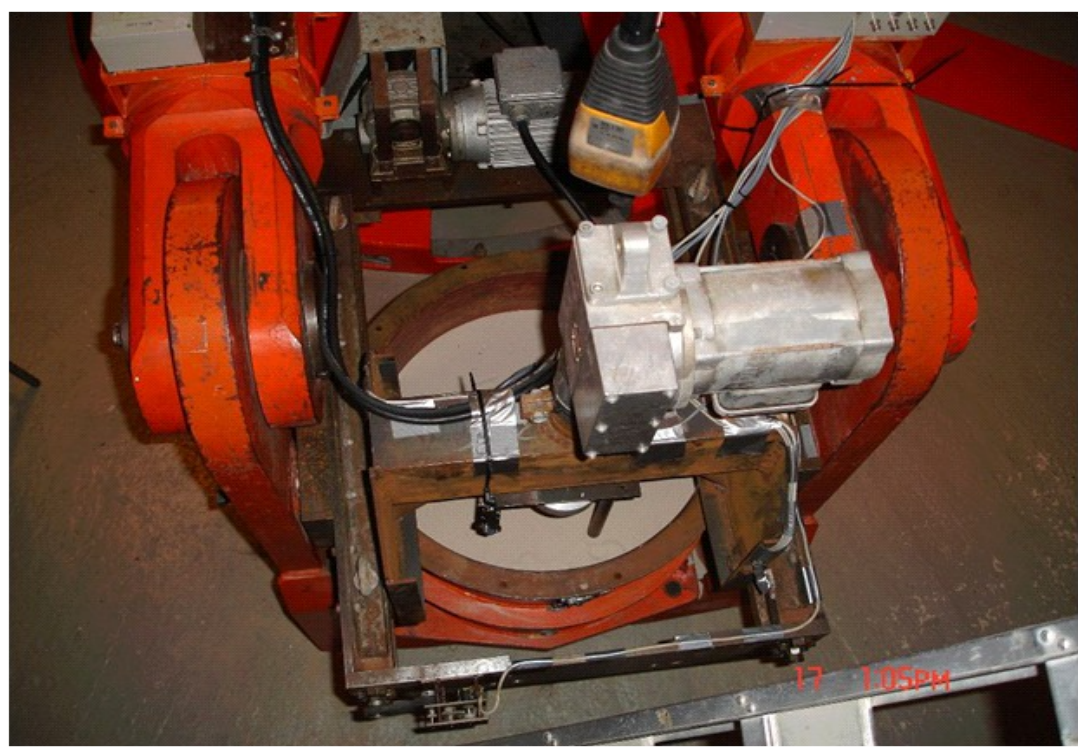

Figure 3.14 CPT setup mounted in centrifuge.

A mini-penetrometer (MCP) was purchased in 1994 to verify soil parameters of prepared samples, and it has been refitted in 2006, where two strain-gauge full-bridges have been replaced. The length of the cone is $91.3 \mathrm{~mm}$ and the diameter is $11.3 \mathrm{~mm}$, and it has been supplied with a rod with an approximate length of $280 \mathrm{~mm}$ giving a possible penetration depth of $300 \mathrm{~mm}$. The MCP is shown in Figure 3.15.

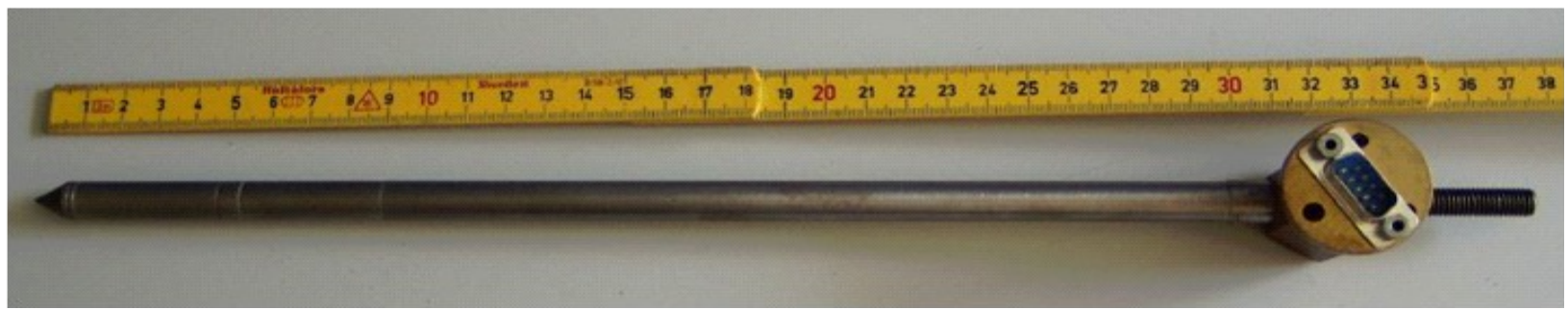

Figure 3.15 Mini penetrometer (MCP). 


\section{Features of the CPT setup:}

- The setup is used in combination with a circular container and it is required that the container is partly filled with a soil sample - the upper $16 \mathrm{~cm}$ of the container must be empty, hence a sample height of $33 \mathrm{~cm}$ is applicable.

- The MCP can measure tip resistance, combined tip and friction resistance and pore pressure. The total driving force is in addition measured.

- The penetrometer frame can move in the horizontal plane along the centre line of the container. It is possible to cover approximate $2 / 3$ of the diameter of the container.

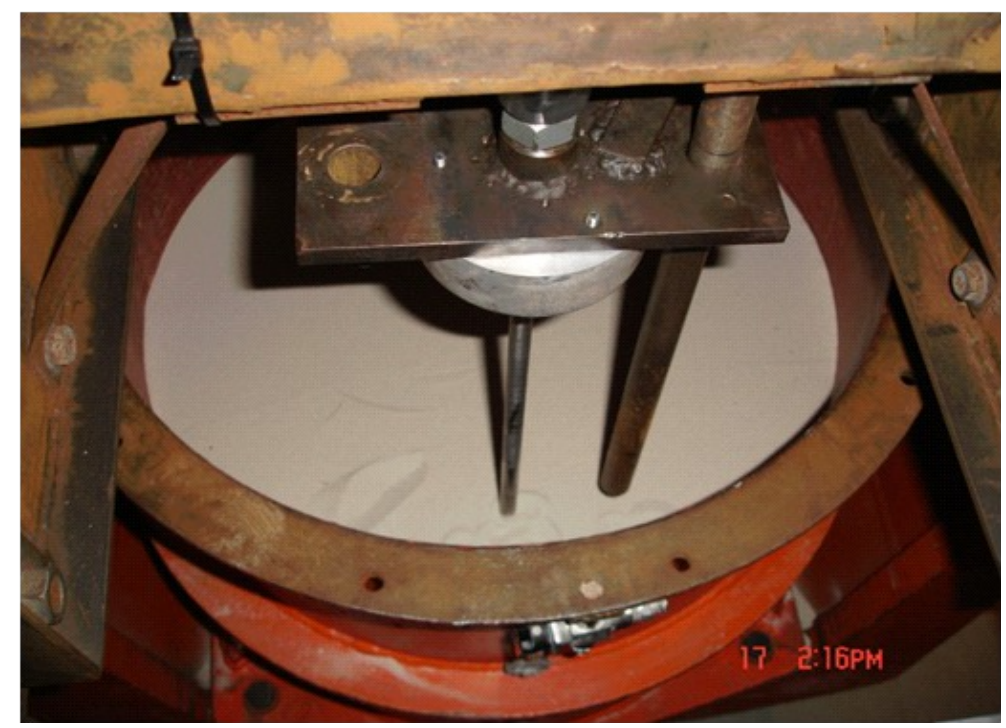

Figure 3.16 Close up of the penetrometer frame with MCP mounted. 
It is important to prepare and apply homogeneous soil samples in centrifuge modelling and the present CPT setup is used to investigate the prepared samples inflight.

A series of CPTs have been carried out and the results from five tests on a single sample are shown in Figure 3.17. The tests are distributed at three different locations in the sample (1-3), and three tests have been carried out at one location (location 2).

The first CPT carried out at each location shows a very homogene sample for the tested depth $(20 \mathrm{~cm})$. The repeated CPTs at location 2 , shows a small depression in the surface where no resistance is measured, and equivalent soil conditions to a depth of $15 \mathrm{~cm}$ below the surface. Below a depth of $15 \mathrm{~cm}$, the repeated CPTs show densification of the soil.

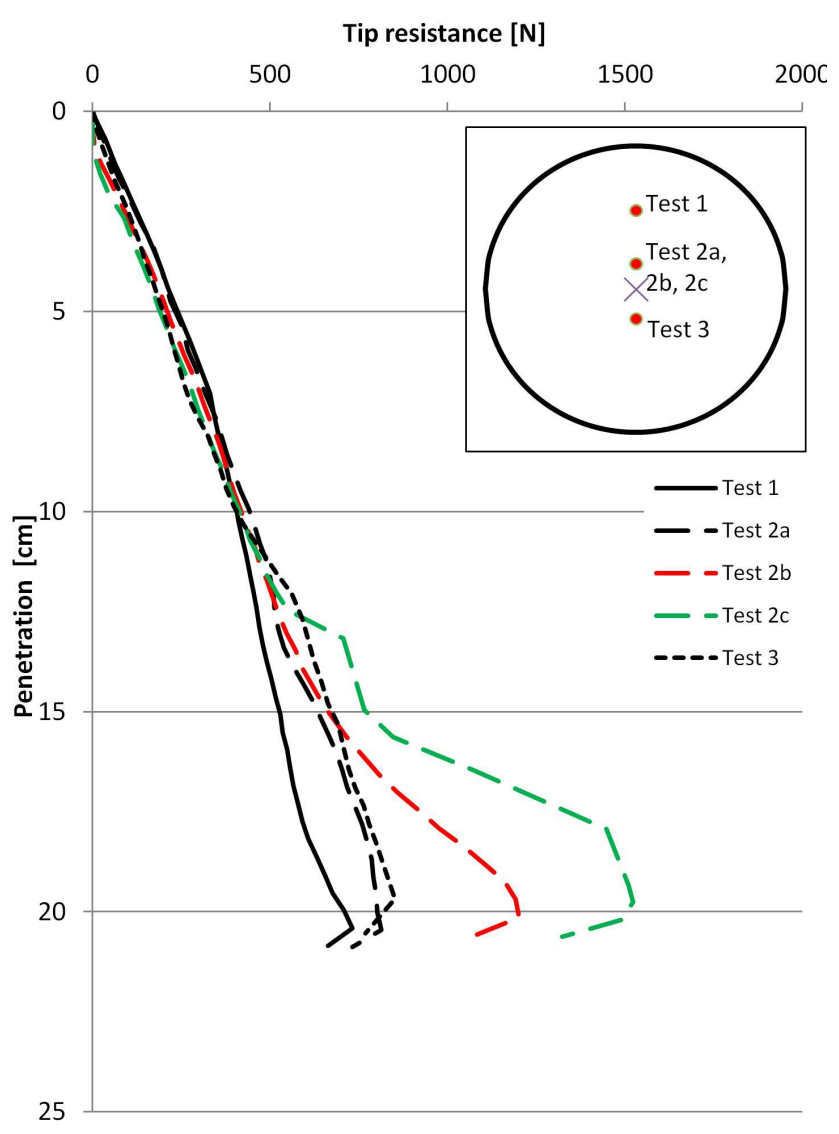

Figure 3.17 CPTs carried out on one sample, measured values.

\subsection{Lateral loading system}

The centrifuge facilities at DTU has over the years been used for research into various geotechnical issues, see Leth et al. (2008) for further references, and a previously developed loading frame for lateral loaded pile groups has formed the basis for the lateral loading system applied for the current research on large diameter piles. The existing frame has been updated with among other things new main motor, new displacement measurement equipment, load cells, pile fixity setup and control system. This section describes the lateral loading system.

\subsubsection{Loading frame}

A loading frame for tests on laterally loaded piles was constructed by Peder N. Knudsen (Knudsen, 1982), and was used in the Ph.D. study by Haahr (1989). A description of the use of the setup along with the controls of that time is given in Haahr (1989).

The lateral loading frame is based on an outer frame supporting the engine and the loading platform. The loading platform is mounted on at set of radial linear bushings and works as a pile 
cap for the pile(s) tested. The frame fits a circular container with a diameter of $53 \mathrm{~cm}$ and a height of $49 \mathrm{~cm}$. The loading frame is shown in Figure 3.18 and Figure 3.19. The loading frame mounted on the container is sketched in Figure 3.20 along with the main definitions and dimensions,

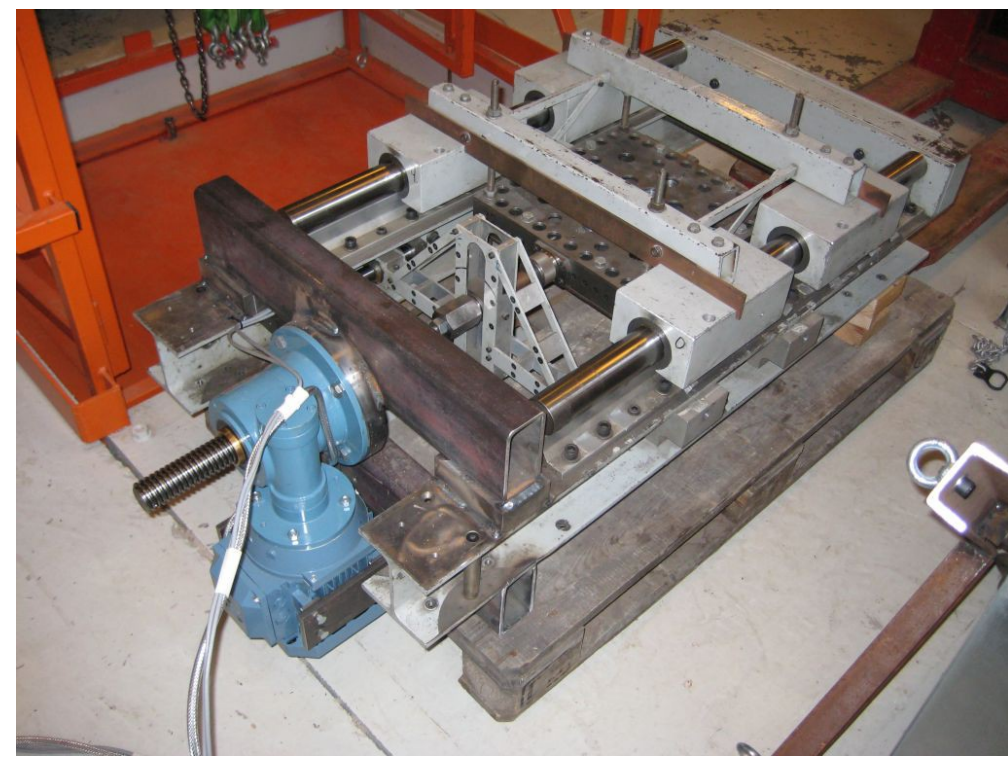

Figure 3.18 Loading frame.

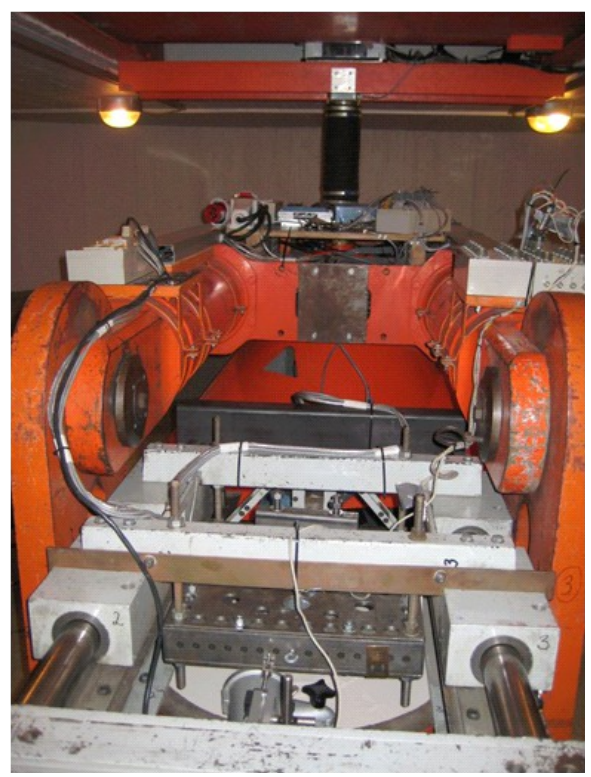

Figure 3.19 Mounted loading frame.

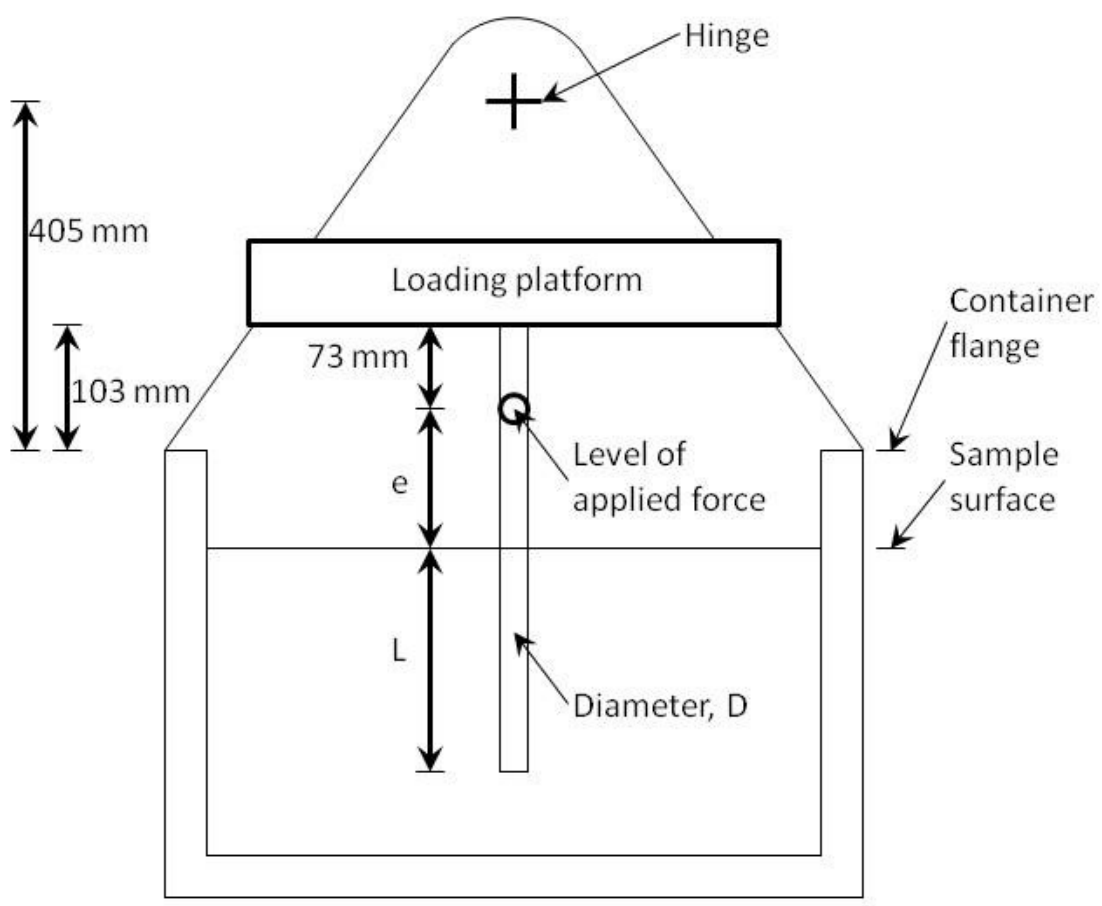

Figure 3.20 Sketch of mounted loading frame with main definitions. 
Each pile is mounted in the loading platform by use of a connection piece consisting of a hinge and a load cell, see Figure 3.22 for assembled pile, load cell and hinge.

The load cell is fixed in the loading platform by an expansion bolt. The hinge can as an option be replaced by a fixed connection.

Lateral displacement is measured by use of a linear variable differential transformer (LVDT) mounted on the outer frame and attached to the loading platform, see Figure 3.21.

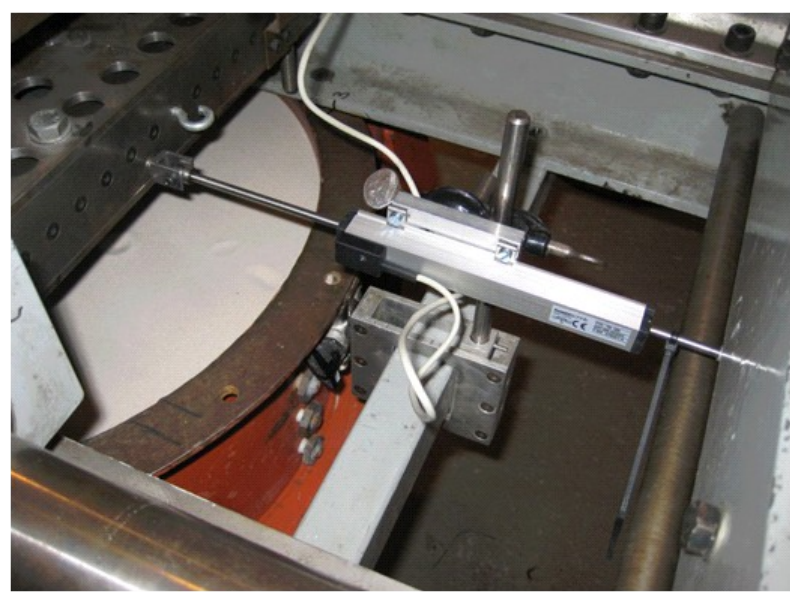

Figure 3.21 LVDT mounted on the loading frame

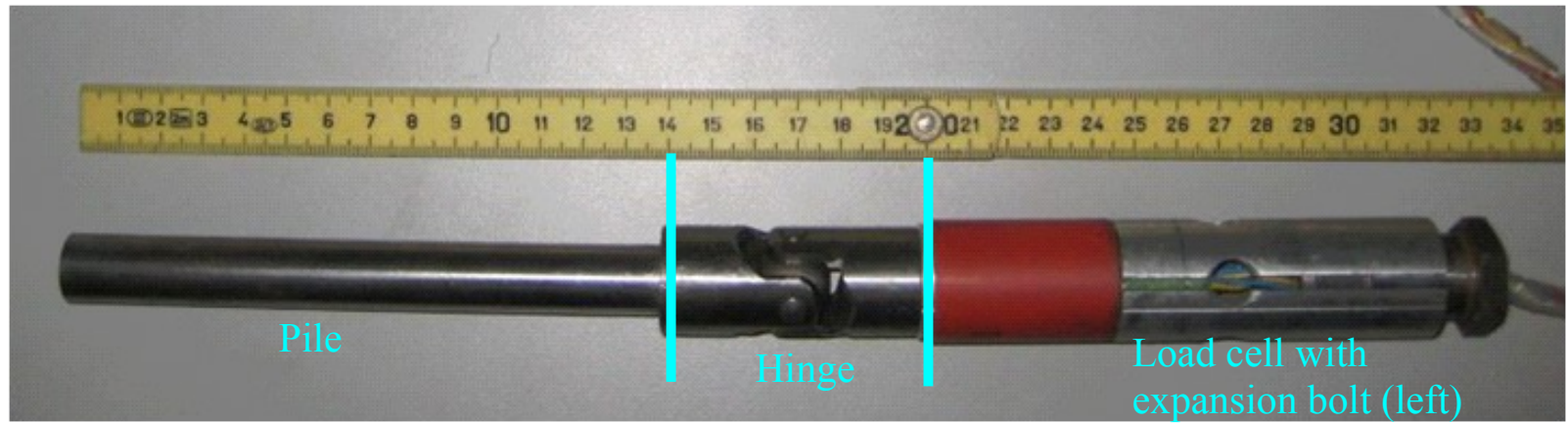

Figure 3.22 ø16 $\mathrm{mm}$ pile with hinge and load cell.

The lateral loading frame has in connection with the present research been renovated / upgraded with following components:

- New main AC motor and frequency converter for control.

- Application of two micro switches to prevent out of bound movement and consequential damage to the setup. The loading platform has a horizontal displacement range of $15.4 \mathrm{~cm}$.

- New displacement transducer to monitor the lateral displacements of the loading frame.

- New load cell produced at DTU. The new load cell is made of high strength steel (CrNI) and has a measuring range of $\pm 18 \mathrm{kN}$. It is a supplement to the existing load cells which have a measuring range of $\pm 2 \mathrm{kN}$.

- Application of strain gauge amplifier for the load cells directly at the loading platform, see the left of Figure 3.23.

- Adjustment of loading platform to allow installation of $ø 40 \mathrm{~mm}$ model pile.

- Mounting on loading platform to fix piles in axial direction. This was included when it was observed that the pile had an upward movement during cyclic lateral loading. The mounting is shown to the right in Figure 3.23. 

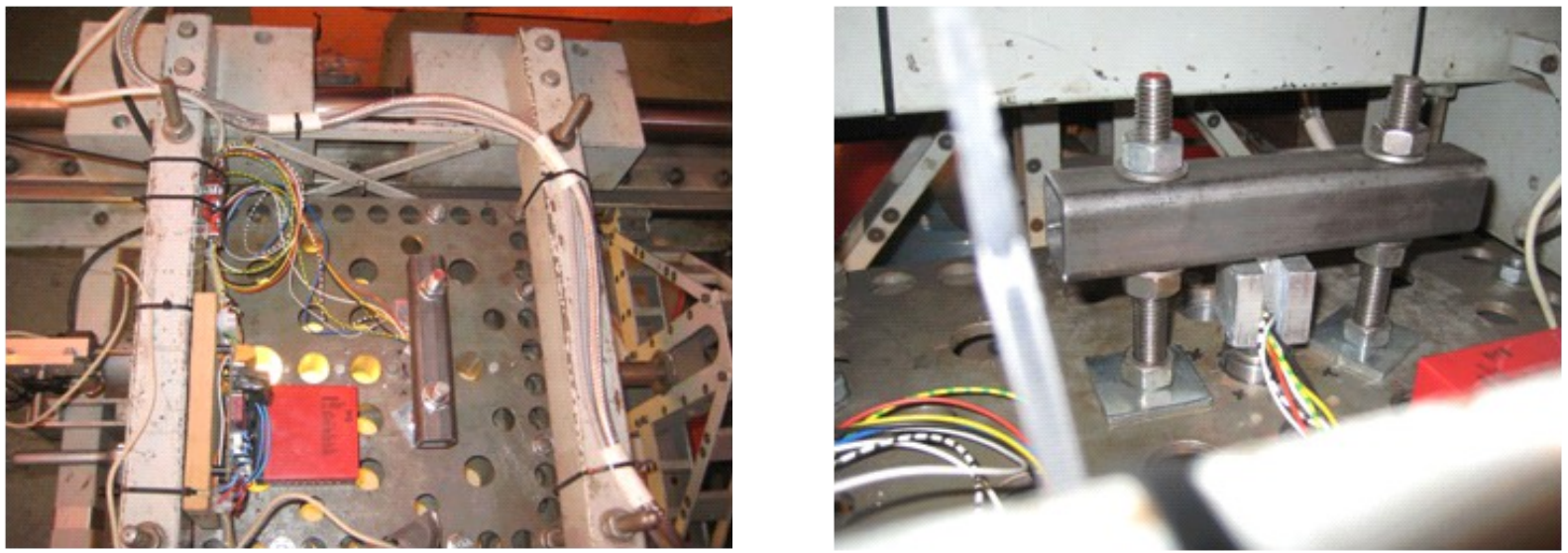

Figure 3.23 Strain gauge amplifier and mounting for axial fixity of pile.

The usability of the lateral loading frame is:

- One way lateral loading of a monopile or a pile group with either fixed pile head or free pile head. The piles are fixed in axial direction.

- Pile model diameter is maximum $40 \mathrm{~mm}$ for testing mono piles and $28 \mathrm{~mm}$ for tests with pile groups.

- The updated control system is based on a LabVIEW interface and both static and cyclic tests can be carried out.

A further description of the lateral loading system is given in Leth (2011).

\subsubsection{Measurement noise}

The first series of cyclic tests on piles with a diameter of $1 \mathrm{~m}$, have been carried out as a part of a master study and initial data processing revealed significant noise in the measured signal, see Figure 3.24 left.

Based on a method described by Hansen (2008), a filter for the post processing have been created (Klinkvort 2009a). A spectral analysis showed that a high frequency background noise was present during the tests. A low pass filter have been applied to the data with a cut off frequency of $0.48 \mathrm{~Hz}$. The effect
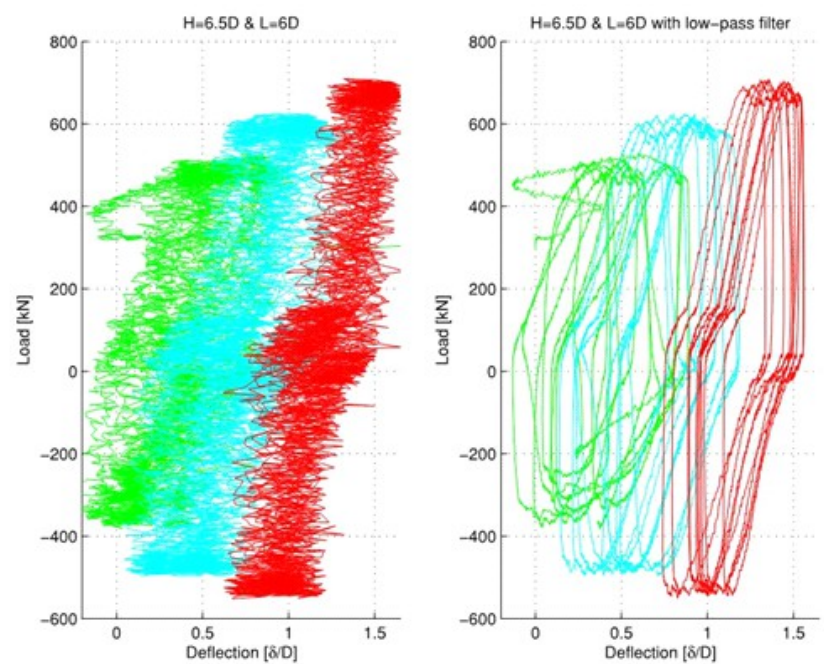

Figure 3.24 Plot of raw (left) and filtered data (right), Figure 6.16 from Klinkvort (2009a). of the applied filter can be see in Figure 3.24 right. 


\subsection{Test scheme}

\subsubsection{General considerations}

The present research has been narrowed to investigate the static and cyclic behaviour of stiff piles with a diameter of 1-3 $\mathrm{m}$ in dry sand by use of centrifuge modelling and to compare the findings with the standard $p-y$ curves. It has been chosen to apply piles with a slenderness ratio of 6 to 10 .

Basic definitions for the piles are presented in Figure 3.25.

The planned test programme is presented in Table 3.2. The tests have been carried out with a load eccentricity for the prototype pile of $2.5 \mathrm{~m}$ to $3.0 \mathrm{~m}$ above the sand surface.
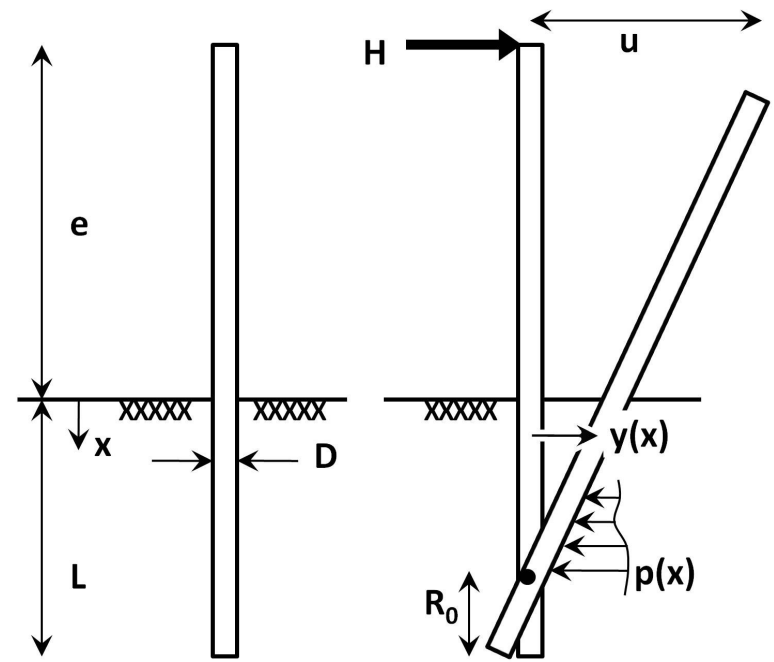

Figure 3.25 Basic pile definitions.

A series of tests on piles with a constant diameter of $1 \mathrm{~m}$ and varying embedment length and load eccentricity have been carried out in connection with the present research and the results are in detail given in Klinkvort (2009a) and Klinkvort et al. (2010). This supplementary test programme is presented in Table 3.3.

Table 3.3 Supplementary test programme, prototype scale.

\begin{tabular}{|c|c|c|}
\hline \multirow{2}{*}{$\begin{array}{c}\mathrm{D} \\
{[\mathrm{m}]}\end{array}$} & $\begin{array}{c}\mathrm{e} \\
{[\mathrm{D}]}\end{array}$ & $\begin{array}{c}\mathrm{L} \\
{[\mathrm{D}]}\end{array}$ \\
\hline \multirow{2}{*}{1} & 2.5 & $6 / 8 / 10$ \\
\cline { 2 - 3 } & 4.5 & $6 / 8 / 10$ \\
\cline { 2 - 3 } & 6.5 & $6 / 8 / 10$ \\
\hline
\end{tabular}

Static and cyclic tests have been carried out for each of the piles listed in Table 3.2 and Table 3.3 and the principles of the test types are considered in the following two sections.

\begin{tabular}{|c|c|c|}
\hline $\begin{array}{c}\mathrm{D} \\
{[\mathrm{m}]}\end{array}$ & $\begin{array}{c}\mathrm{e} \\
{[\mathrm{D}]}\end{array}$ & $\begin{array}{c}\mathrm{L} \\
{[\mathrm{D}]}\end{array}$ \\
\hline 1 & 2.5 & $6 / 8 / 10$ \\
\hline 2 & 1.429 & $6 / 8 / 10$ \\
\hline 3 & 1.0 & $6 / 8$ \\
\hline
\end{tabular}

$\begin{array}{ll}\text { e: } & \text { Load eccentricity } \\ \text { L: } & \text { Embedment length } \\ \text { D: } & \text { Diameter } \\ \text { H: } & \text { Load on pile top } \\ \mathrm{u}: & \text { Deflection at pile top } \\ \mathrm{R}_{0}: & \text { Distance from pile tip to } \\ & \quad \text { rotation centre. } \\ \mathrm{x}: & \text { Depth below sand surface } \\ \mathrm{p}(\mathrm{x}): & \text { Soil resistance at depth } \mathrm{x} \\ \mathrm{y}(\mathrm{x}): & \text { Pile deflection at depth } \mathrm{x} .\end{array}$

Table 3.2 Main test programme, prototype scale. 


\subsubsection{Outline of static tests}

The main focus in the investigation on the static behaviour includes (see also Figure 3.26):

- Initial stiffness of the pile response

- Ultimate capacity

- General (elasto-plastic) behaviour In the static tests the load at the pile top is increased with with a constant rate until bearing capacity is reached.

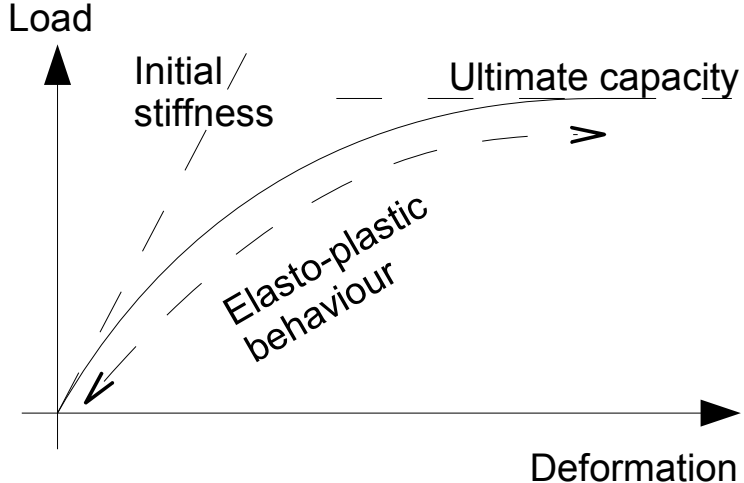

Figure 3.26 Idealized load-deformation curve for a monopile.

The results from the tests are given in Leth (2011) and further presented in chapter 4.

\subsubsection{Outline of cyclic tests}

The main focus of the cyclic tests are to investigate the behaviour of the pile in dry sand with respect to accumulation of deformations and change in stiffness.

Cyclic loading can in principle be considered in two different ways:

- Deformation controlled.

The loading follows a defined

deformation cycle and the strength degradation is observed.

- Load controlled.

The loading follows a defined load cycle and the change in stiffness and deformation is observed, with possible

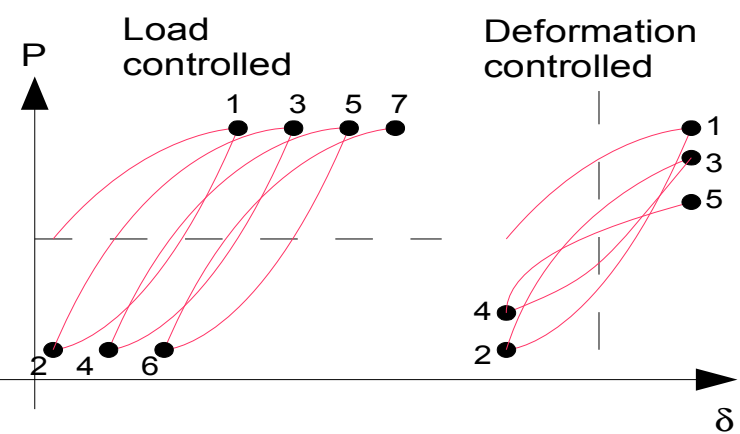

Figure 3.27 Load $(P)$ controlled vs. deformation $(\delta)$ controlled load cycles. softening or hardening.

It is in the research of interest to investigate the behaviour of a monopile subject to cyclic loading, in principle modelling an OWT, hence the focus is on the stiffness behaviour from a defined cyclic load, and hence focus on load controlled tests. 
The basis of the planned loading scheme is illustrated in Figure 3.28 which consists of 5 elements:

- Static loading to average load level.

- Cyclic loading part 1. Relative high load amplitude.

- Cyclic loading part 2. Reduced load amplitude.

- Cyclic loading part 3. Relative high load amplitude.

- Static loading until failure.

The results from the cyclic tests are given in Leth (2011) and further presented in chapter 5.

It is noted that Leth (2011) has a misprint in Appendix B "Results from lateral load tests" - all the presented results from cyclic load tests are not scaled which is contrary to what is written in the appendix.

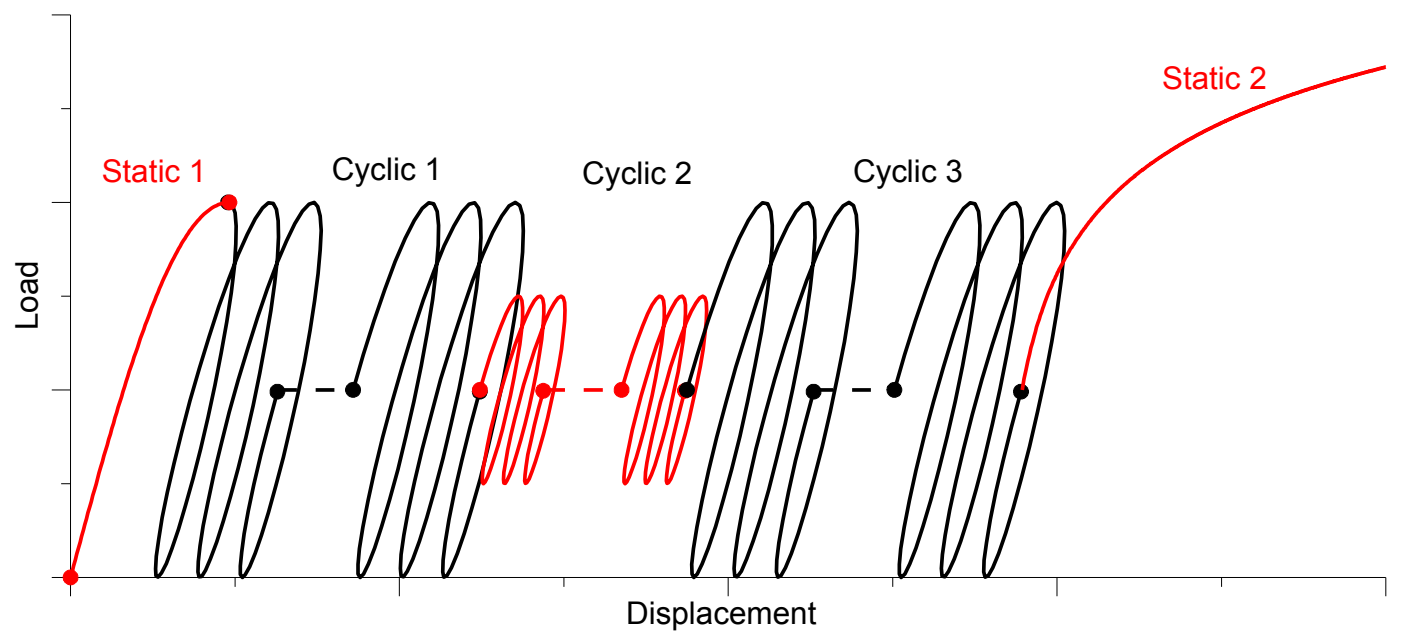

Figure 3.28 Conceptual loading scheme.

\subsection{Model piles}

The subject of the research has been to investigate the behaviour of lateral loaded stiff piles, which includes both the elasto-plastic behaviour and the ultimate bearing capacity. Based on initial theoretical considerations of the bearing capacity it has been determined necessary to apply solid steel test piles of high strength $\mathrm{NiCr}$ steel to ensure sufficient structural bending capacity.

The prototype piles with a diameter of 1-3 m (see section 3.5.1 for further details) have been modelled by tests piles with a diameter in the range of 16-40 mm, and an embedment length between 96 and $320 \mathrm{~mm}$. The dimensions of the applied test (model) piles are given in Table 3.4, a total of 8 different piles for the main test programme.
Table 3.4 Dimensions and scaling for model piles in main test programme.

\begin{tabular}{|c|c|c|c|}
\hline $\begin{array}{c}\mathrm{d} \\
{[\mathrm{mm}]}\end{array}$ & $\begin{array}{c}\mathrm{e} \\
{[\mathrm{mm}]}\end{array}$ & $\begin{array}{c}\mathrm{L} \\
{[\mathrm{mm}]}\end{array}$ & $\begin{array}{c}\mathrm{N} \\
{[\mathrm{mm}]}\end{array}$ \\
\hline 16 & 40 & $96 / 128 / 160$ & 62.5 \\
\hline 28 & 40 & $168 / 224 / 280$ & 71.4 \\
\hline 40 & 40 & $240 / 320$ & 75.0 \\
\hline
\end{tabular}


Use of solid steel piles with a slenderness ratio $(L / D)$ of 6 to 10 in the physical tests appear to ensure rigid behaviour. The behaviour of a pile with a given diameter and length can be evaluated by use of following terms from Poulos and Hull (1989):

Rigid behaviour:

$$
L<1.48\left(\frac{E_{p} \cdot I_{p}}{E_{s}}\right)^{0.25}
$$

Flexible behaviour:

$$
L>4.44\left(\frac{E_{p} \cdot I_{p}}{E_{s}}\right)
$$

Where $E_{p} \cdot I_{p}$ is the bending stiffness of the pile and $E_{s}$ is Young's modulus for the soil.

Equations 3.5 and 3.6 are plotted in Figure 3.29 along with the pile characteristics for the tested piles. Young's modulus for steel is $210,000 \mathrm{MPa}$ and the average modulus for the soil along the embedment length is determined for the different piles.

The relations described by equations 3.5 and 3.63.6 are based on that the right part of equation 3.63.6 equals the expression for the critical length. The critical length is defined as the pile length where a reduction in displacement cannot be achieved by increasing the length.

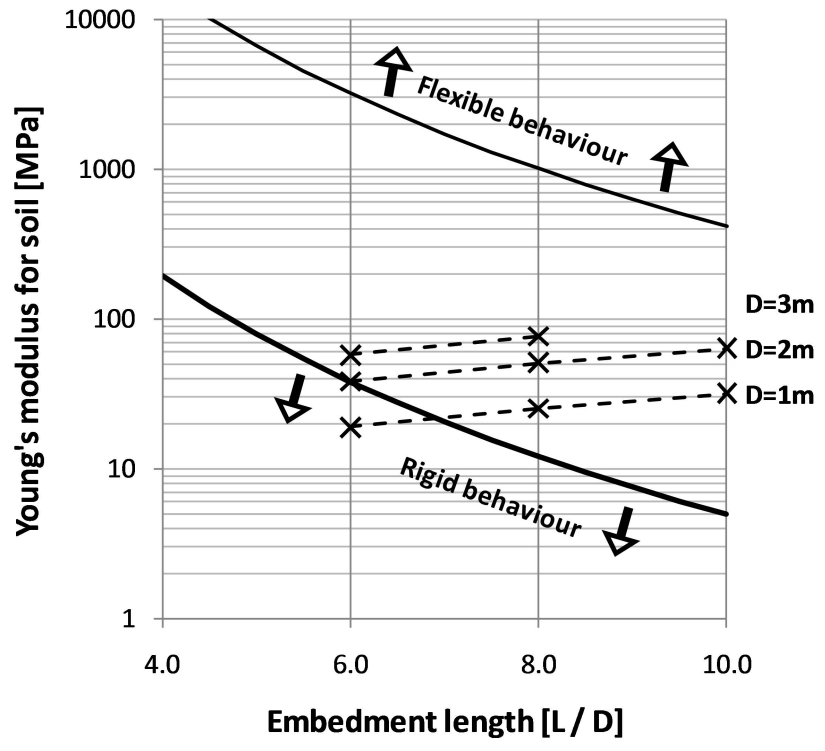

Figure 3.29 Behaviour of pile.

It is by Poulos and Hull (1989) argued that reducing the pile length to a third of the critical length ensures a rigid behaviour of the pile and hence the values of 1.48 in equation 3.5. The critical lengths for the three diameters in question are $16.6 \mathrm{~m}, 28.8 \mathrm{~m}$ and $39.9 \mathrm{~m}$.

Even as the representative soil stiffness for the piles falls in between the calculated boundaries for the piles applied is it expected that the pile is behaving relative rigid as it in general is placed relative closest to the rigid boundary and that the respective critical lengths exceed the applied pile lengths by more than $60 \%$. 



\section{Static behaviour}

\subsection{Test results}

A total of 15 static tests have been carried out for the present research, see Table 4.1.

The test program presented in Table 4.1 consists of:

- 3 initial tests for test of setup.

- 11 main tests to investigate the static behaviour of prototype piles with diameter of 1-3 m and an embedment length of 6 to 10 times the diameter. The diameter of the model piles is 16,28 and $40 \mathrm{~mm}$, respectively.

- 1 supplementary test carried out related to the supplementary test program described in chapter 3.5.1.

Relative densities for the samples applied in the main test series are presented in Table 4.2.

The presented results in this section is measured values and not scaled to prototype scale according to the scaling principles described in section 2.4.2.
Table 4.1 Static test program. Model pile dimensions.

Initial tests

\begin{tabular}{|c|c|c|c|}
\hline $\mathrm{D}$ & $\mathrm{L}=190 \mathrm{~mm}$ & $\mathrm{~L}=388 \mathrm{~mm}$ & $\mathrm{e}$ \\
\hline $16 \mathrm{~mm}$ & 2 & $1^{1)}$ & $2.5 \mathrm{D}$ \\
\hline
\end{tabular}

Main tests

\begin{tabular}{|c|c|c|c|c|}
\hline $\mathrm{D}$ & $\mathrm{L}=6 \mathrm{D}$ & $\mathrm{L}=8 \mathrm{D}$ & $\mathrm{L}=10 \mathrm{D}$ & $\mathrm{e}$ \\
\hline $16 \mathrm{~mm}$ & 2 & $2^{4)}$ & 1 & $2.5 \mathrm{D}$ \\
\hline $28 \mathrm{~mm}$ & 1 & 1 & 1 & $1.429 \mathrm{D}$ \\
\hline $40 \mathrm{~mm}^{2)}$ & $2^{3)}$ & 1 & NA & $1 \mathrm{D}$ \\
\hline
\end{tabular}

Supplementary tests

\begin{tabular}{|c|c|c|}
\hline $\mathrm{D}$ & $\mathrm{L}=8$ & $\mathrm{e}$ \\
\hline $16 \mathrm{~mm}$ & 1 & $4.5 \mathrm{D}$ \\
\hline
\end{tabular}

1) The bend due to low structural capacity

2) 2 static tests have been carried out by the laboratory personnel at DTU.BYG (Klinkvort 2009b)

3) One test is incomplete due to mechanical failure of hinge.

4) Problems with measurements and strain gauge amplifier in one test.

Table 4.2 Relative densities for samples applied to the main tests.

\begin{tabular}{|c|c|c|c|}
\hline $\mathrm{D}$ & $\mathrm{L}=6 \mathrm{D}$ & $\mathrm{L}=8 \mathrm{D}$ & $\mathrm{L}=10 \mathrm{D}$ \\
\hline $16 \mathrm{~mm}$ & 0.826 & 0.832 & 0.870 \\
\hline $28 \mathrm{~mm}$ & 0.840 & 0.835 & 0.790 \\
\hline $40 \mathrm{~mm}$ & 0.855 & 0.871 & NA \\
\hline
\end{tabular}

There has, as noted in Table 4.1, been issues with some of the tests:

- Structural failure of pile (bending).

- Mechanical failure of hinge between pile and load cell.

- Defective measurements with failing strain gauge amplifier.

It has been experienced in some tests that the initial part of the load-displacement curves is missing due to some mishap in the data logging, see Figure 4.1. It is seen by comparison of the various tests on piles with same model dimensions and test conditions, that the imperfect load-displacement curve for the static test can be supplemented and a compiled curve obtained, see Figure 4.2. E.g. for 
pile with $D=40 \mathrm{~mm}, L=6 D$ and $e=1 D$ exists a full static test, a static test with mechanical failure of hinge and initial static loading of the cyclic test

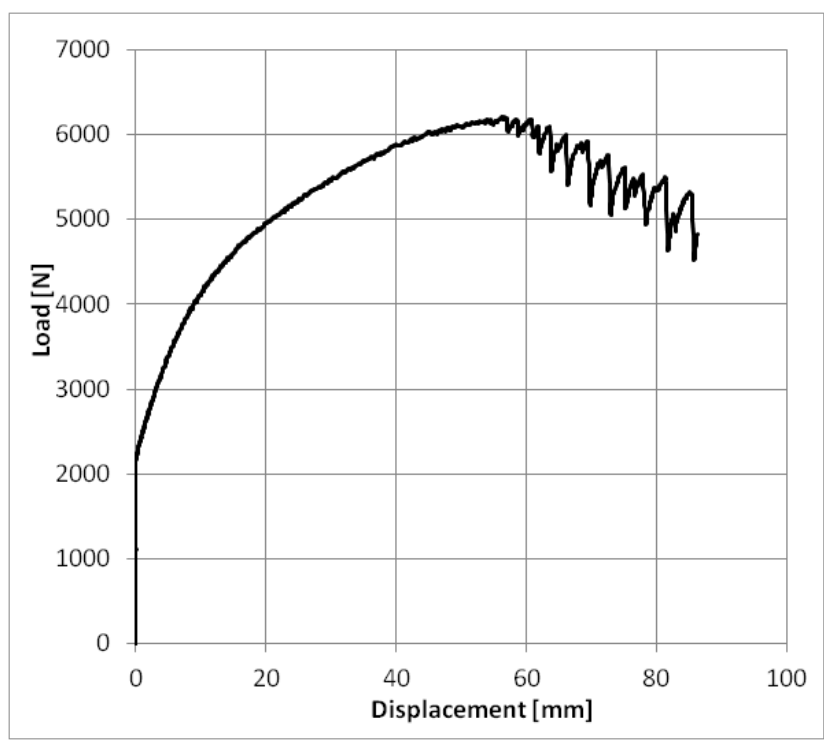

Figure 4.1 Sample, imperfect load-displacement curve (pile with $D=40 \mathrm{~mm}, L=6 D$ and $e=1 D$ ).

The measured, and if necessary compiled, loaddeflection curves for the piles in the main test program are presented in Figure 4.3 to Figure 4.5. The ultimate capacity measured for each of the 8 tests presented in Figure 4.3 to Figure 4.5 is given in Table 4.3.

The presented load-deformation curves show a tendency to have a relative steep initial curve section up to approximately $70 \%$ of the ultimate capacity followed by a more flat curve section until reached failure. The eight curves presented in Figure 4.3 to Figure 4.5 seem to have the same elasto-plastic behaviour and a normalisation of each curve with measured ultimate capacity and corresponding deformation is presented in Figure 4.6. The normalised curves for the investigated piles show a very close resemblance thus illustrating that the investigated piles show the same general behaviour. In conclusion a general stiff pile behaviour.

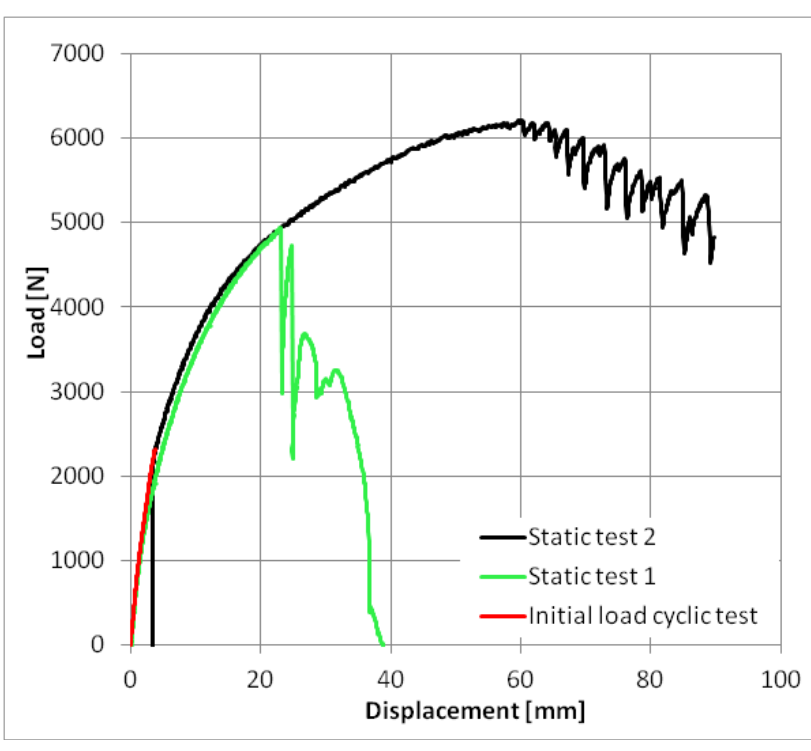

Figure 4.2 Comparison of static load-displacement curves from different tests (pile with $D=40 \mathrm{~mm}, L=6 D$ and $e=1 D$.

Table 4.3 Measured ultimate capacity from static tests.

\begin{tabular}{|c|c|c|}
\hline $\begin{array}{c}\text { Diameter } \\
(\mathrm{D})\end{array}$ & $\begin{array}{c}\text { Embedment } \\
\text { length (L) }\end{array}$ & $\begin{array}{c}\text { Measured ultimate } \\
\text { capacity (Hmax) }\end{array}$ \\
\hline \multirow{3}{*}{$16 \mathrm{~mm}$} & $6 \mathrm{D}$ & $326 \mathrm{~N}$ \\
\cline { 2 - 3 } & $8 \mathrm{D}$ & $660 \mathrm{~N}$ \\
\cline { 2 - 3 } & $10 \mathrm{D}$ & $1271 \mathrm{~N}$ \\
\hline \multirow{2}{*}{$28 \mathrm{~mm}$} & $6 \mathrm{D}$ & $2000 \mathrm{~N}$ \\
\cline { 2 - 3 } & $8 \mathrm{D}$ & $4209 \mathrm{~N}$ \\
\cline { 2 - 3 } & $10 \mathrm{D}$ & $6964 \mathrm{~N}$ \\
\hline \multirow{2}{*}{$40 \mathrm{~mm}$} & $6 \mathrm{D}$ & $6215 \mathrm{~N}$ \\
\cline { 2 - 3 } & $8 \mathrm{D}$ & $11636 \mathrm{~N}$ \\
\hline
\end{tabular}


Following main observations are made from the presented curves:

- The general unloading curve is very steep with only a minor kick back close to the final part of the unloading. This shows a pile response with a very little elastic response. (Figure 4.3 and Figure 4.4)

- Increasing embedment length increases necessary displacement to achieve ultimate bearing capacity. (Figure 4.3 to Figure 4.5 )

- Piles with same physical embedment but different diameter require approximately the same displacement to achieve ultimate capacity, hence no influence from diamter. cf. piles $D=16 \mathrm{~mm} / L=10 D$ vs. $D=28 \mathrm{~mm} / L=6 D$ and $D=28 \mathrm{~mm} / L=8 D$ vs. $D=40 \mathrm{~mm} / L=6 D)$.

- Figure 4.8 shows, despite apparent issues with measurements below $0.15 \mathrm{~mm}$ for piles with a diameter of $28 \mathrm{~mm}$, a diameter influence on the initial stiffness, with increasing initial stiffness with diameter. The figure shows no apparent dependency in initial stiffness with embedment length, though the load-displacement curves diverge after a relative small displacement.

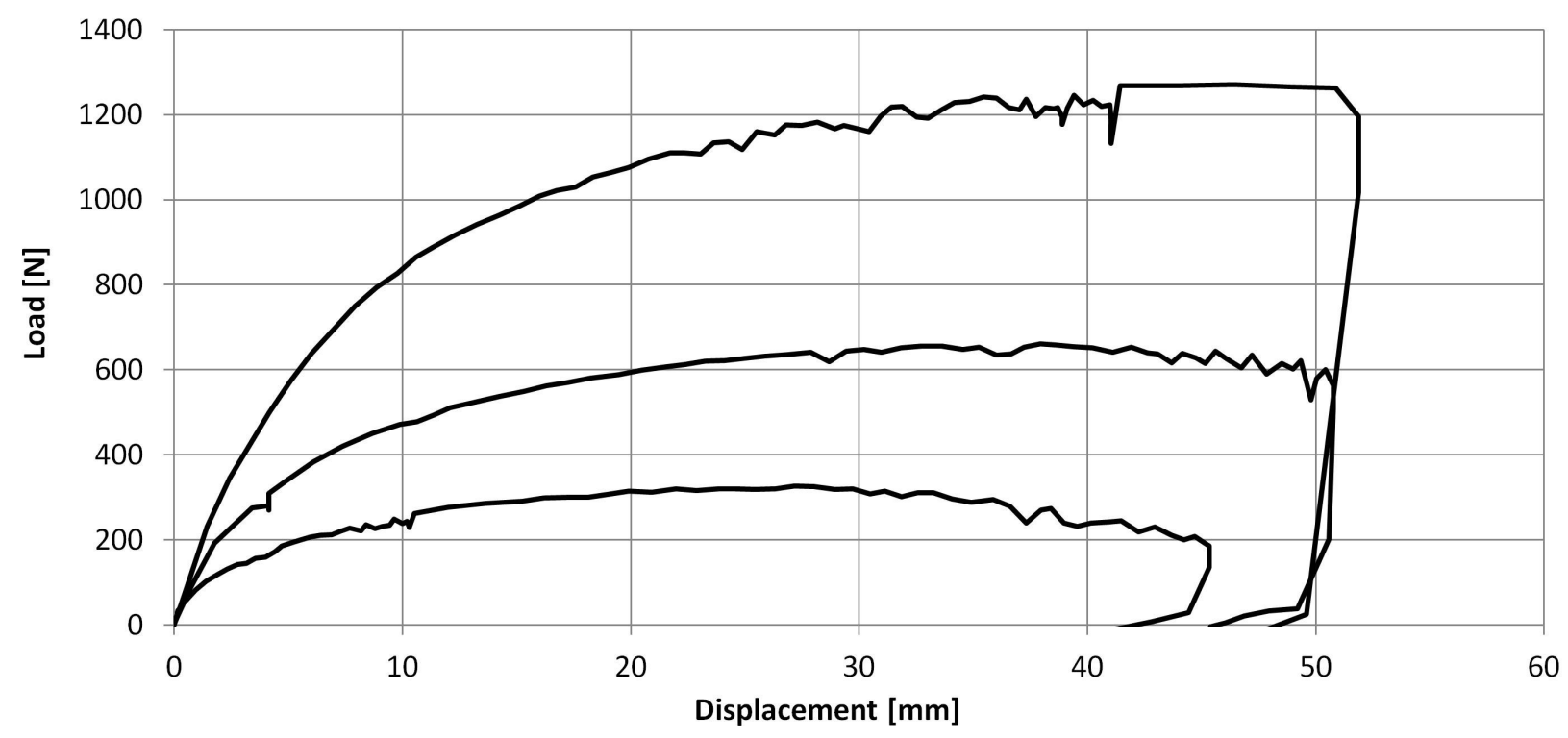

Figure 4.3 Measured load-deflection curve for pile with $D=16 \mathrm{~mm}, L=6 D-8 D-10 \mathrm{D}$ and $e=2.5 \mathrm{D}$. 


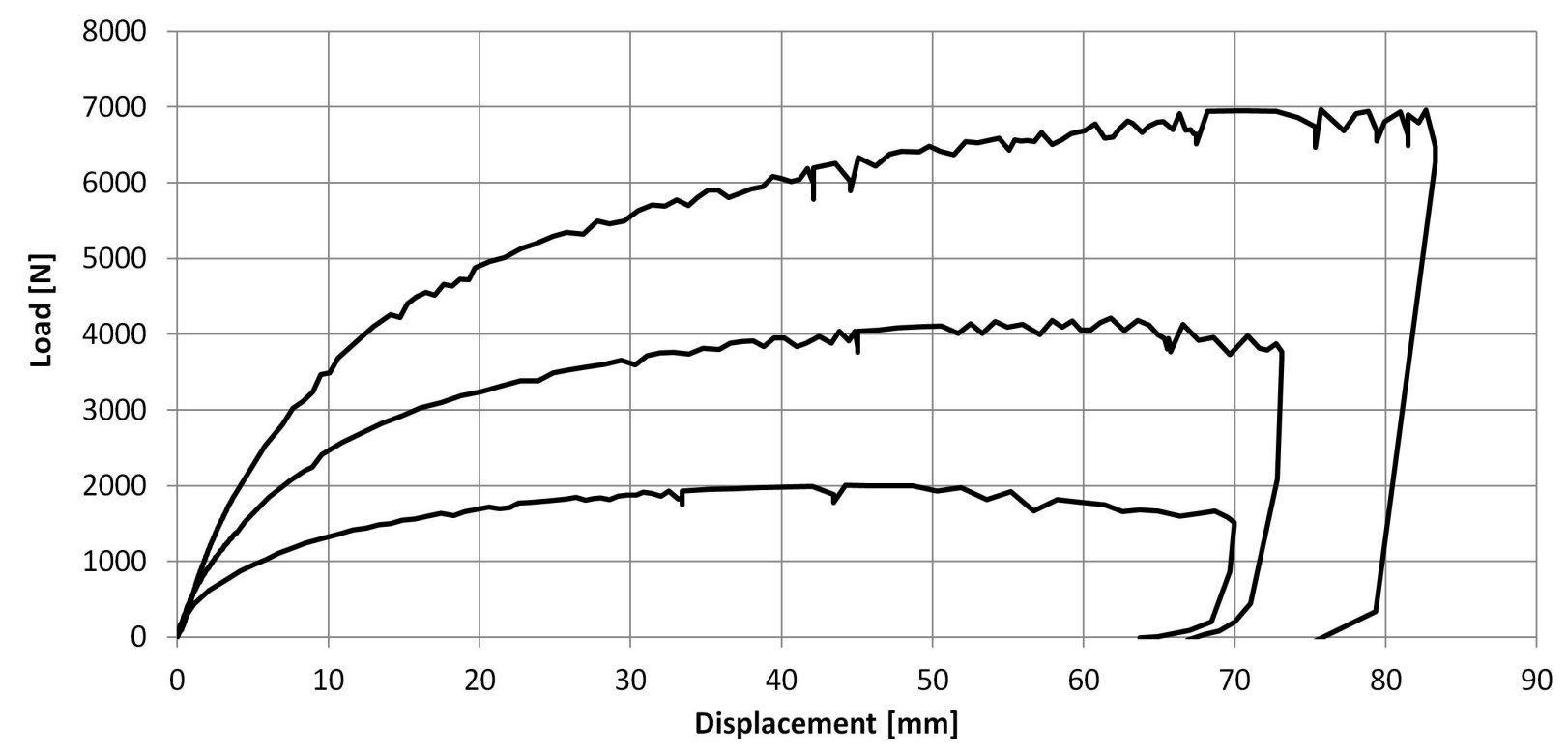

Figure 4.4 Measured load-deflection curve for pile with $D=28 \mathrm{~mm}, L=6-D-8 D-10 D$ and $e=1.43 D$.

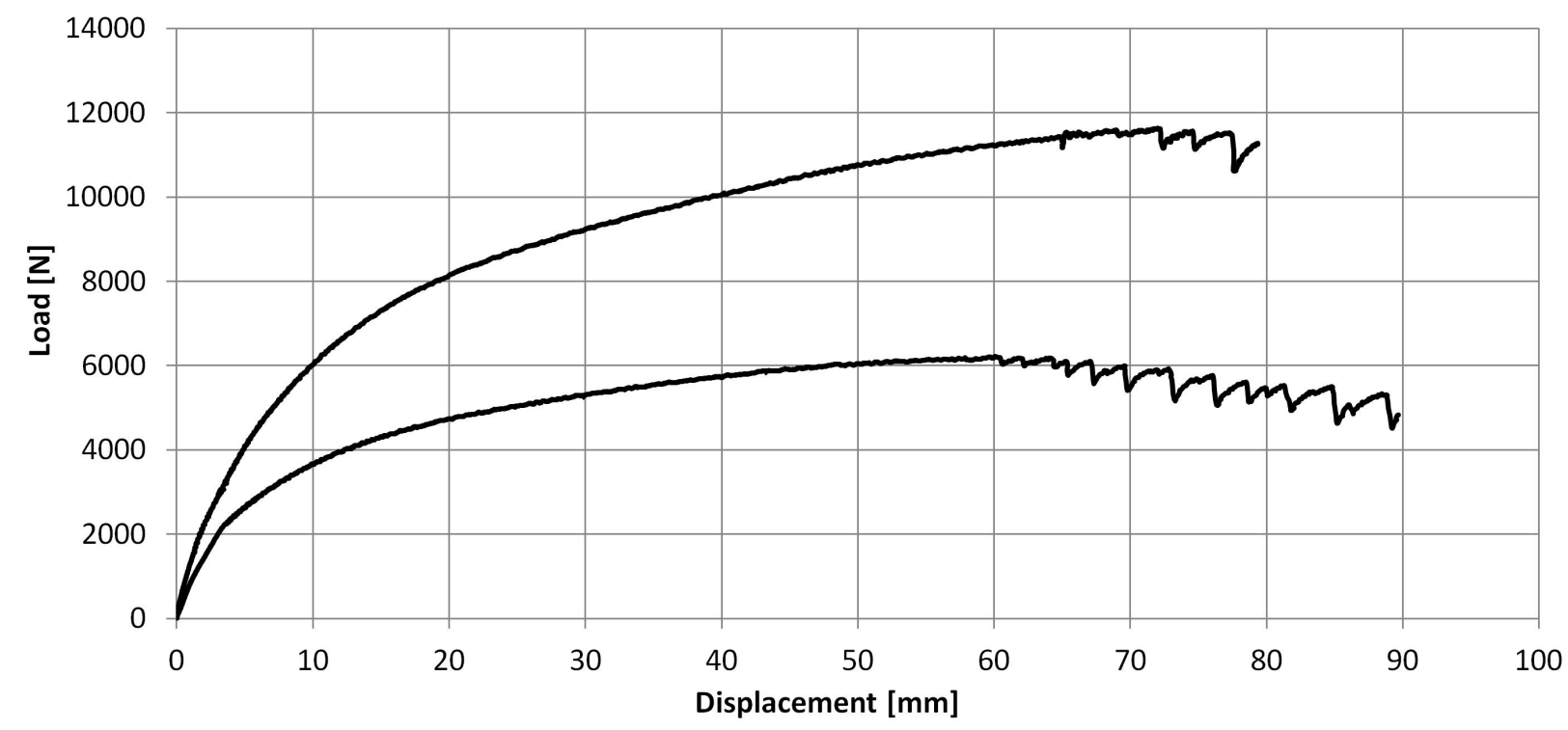

Figure 4.5 Measured load-deflection curve for pile with $D=40 \mathrm{~mm}, L=6 D-8 D$ and $e=1 D$. 


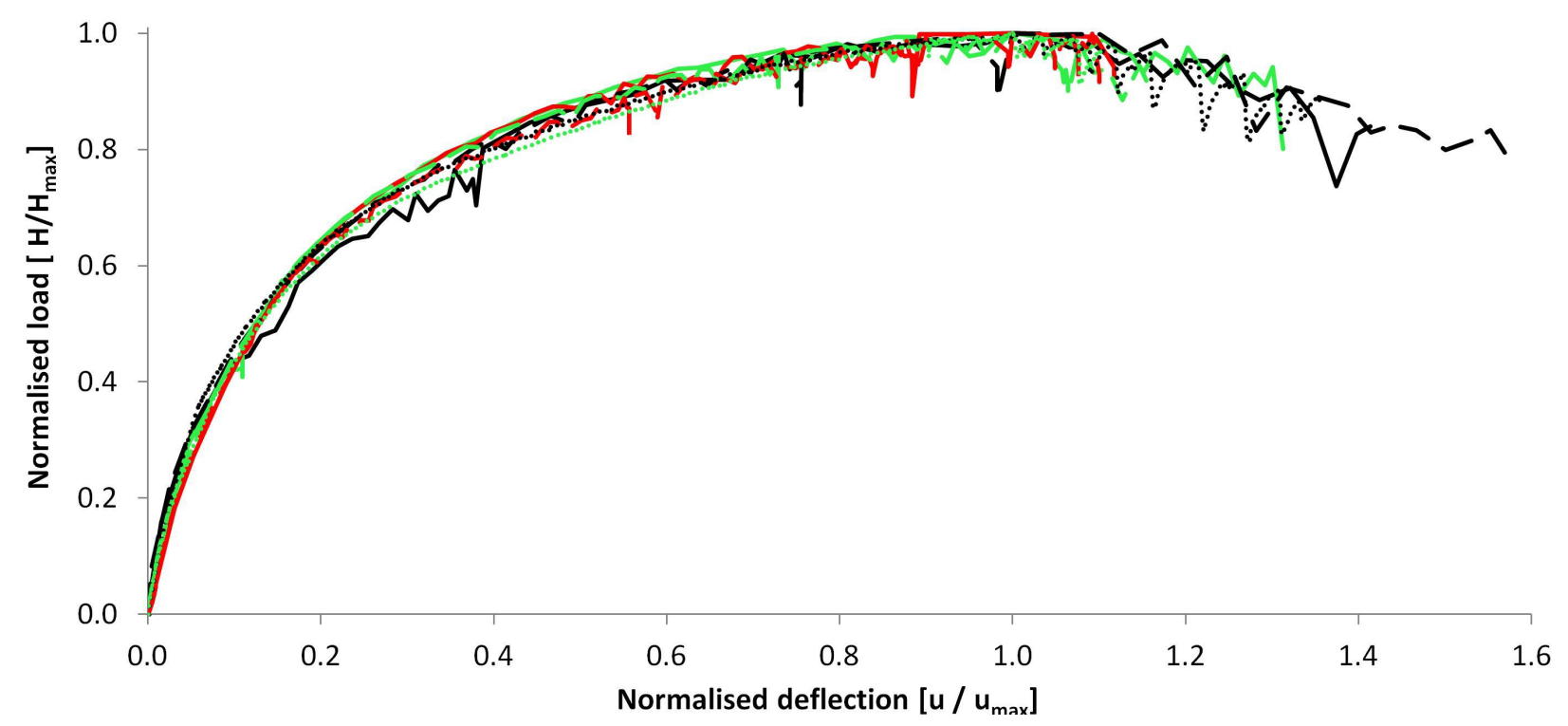

Figure 4.6 Normalised measured load-deflection curves for tested piles.

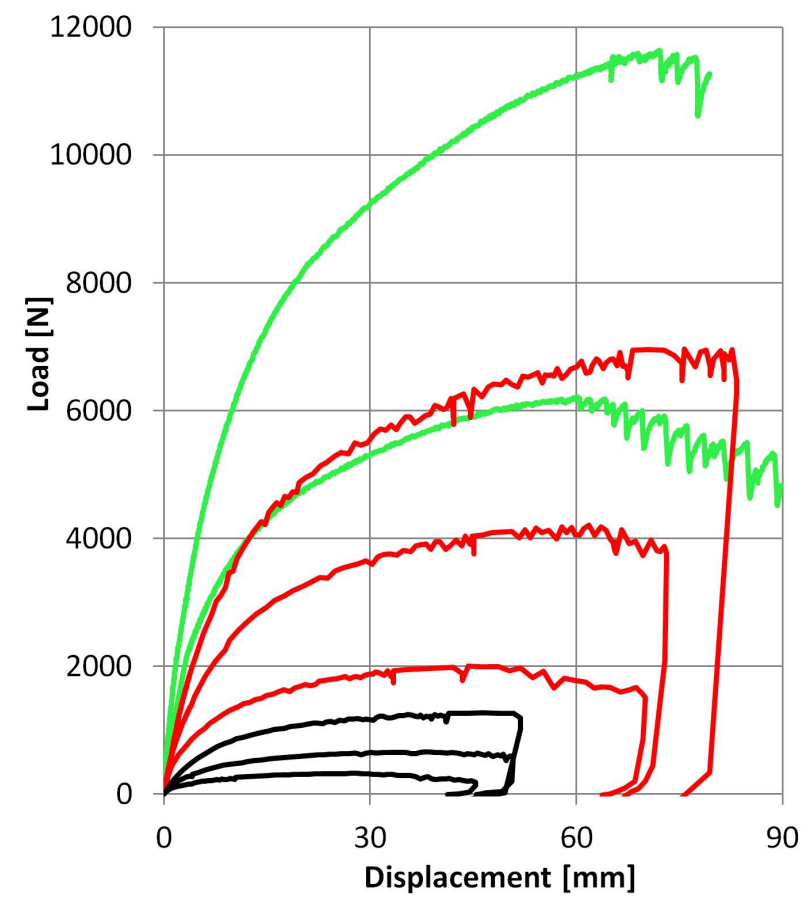

Figure 4.7 Measured load-displacement curve for the eight piles tested. $\varnothing 16 \mathrm{~mm}$ is black, ø28 $\mathrm{mm}$ is red and ø40 $\mathrm{mm}$ is green.

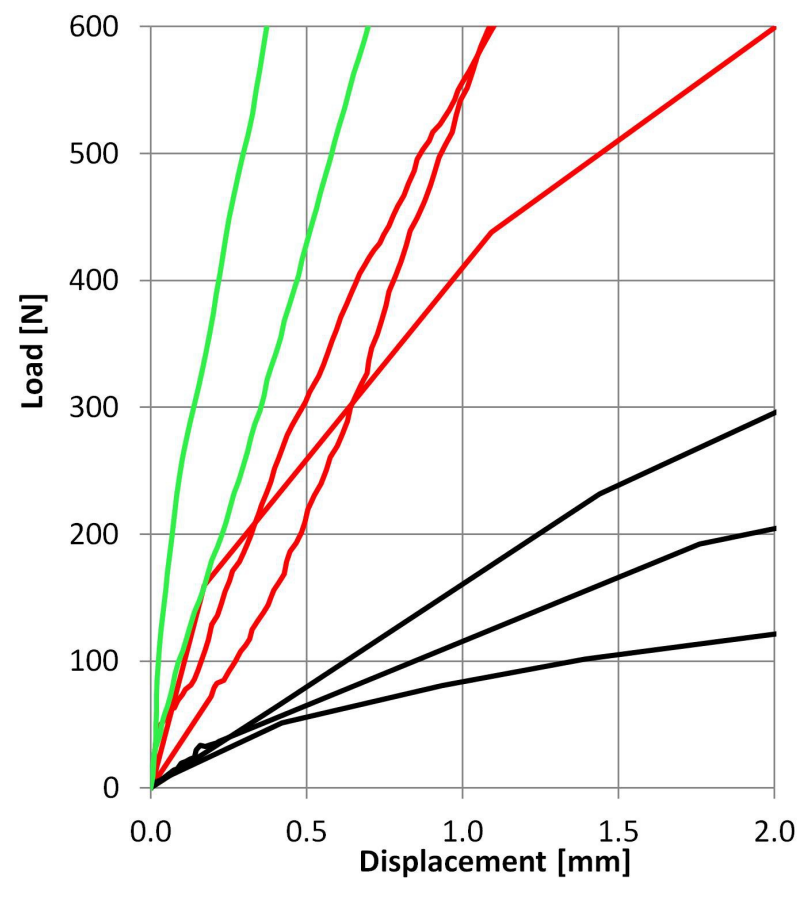

Figure 4.8 Initial part of the measured loaddisplacement curve for the eight piles tested. $ø 16 \mathrm{~mm}$ is black, ø28 $\mathrm{mm}$ is red and $ø 40 \mathrm{~mm}$ is green. 


\subsection{Comparison with load-displacement curves based on standard $p-y$ curves}

The standard static $p-y$ curves described in section 2.2 are in the following compared to the results obtained from centrifuge tests. All results/curves etc. related to what is derived from the standard $p-y$ curves are in the following denominated "standard".

All results presented are in prototype scale, hence all measured data is scaled according to the scaling principles presented in section 2.4.2; a factor of $N$ for the linear dimensions (e.g. length and displacement) and $N^{2}$ for measured force.

It is noted that the test series have been planned to model piles with a diameter of 1,2 and $3 \mathrm{~m}$, but the actual test control has resulted in a slightly reduced scale factor. The actual diameters vary a little with average of $0.983 \mathrm{~m}, 1.949 \mathrm{~m}$ and $2.880 \mathrm{~m}$ for 1,2 and $3 \mathrm{~m}$ respectively. References are in the following made to piles with a diameter of 1,2 and $3 \mathrm{~m}$.

The shape of the standard $p-y$ curves, finite initial stiffness and a significant needed displacement to achieve ultimate capacity (hyperbolic tangent function), leads to a standard pile head response curve (load-displacement curve based on $p-y$ curves) where the ultimate capacity reached after a relative high displacement. It is decided to define ultimate capacity for the standard curves at a inclination of the load-displacment curve equal to $0.2 \%$ of the initial stiffness.

Standard load-displacement curves are calculated for each of 8 tests in the main test program. The calculations are based on properties of the prepared samples, the obtained scaling factor and thus the actual modelled dimensions. It is noted that the tangent friction angle described by equation (3.3) is applied with setting the minor principle stress equal to the vertical stress in the soil. The standard load-displacement curves are presented in Figure 4.9 to Figure 4.11 along with the measured curves. The standard ultimate capacity of each of the 8 pile tests is given in Table 4.4.
Table 4.4 Ultimate capacity from standard loaddisplacement curves.

\begin{tabular}{|c|c|c|}
\hline $\begin{array}{c}\text { Diameter* } \\
(\mathrm{D})\end{array}$ & $\begin{array}{c}\text { Embedment } \\
\text { length (L) }\end{array}$ & $\begin{array}{c}\text { Standard ultimate } \\
\text { capacity (Hmax) }\end{array}$ \\
\hline $1 \mathrm{~m}$ & $6 \mathrm{D}$ & $851 \mathrm{kN}$ \\
\hline & $8 \mathrm{D}$ & $1777 \mathrm{kN}$ \\
\hline $2 \mathrm{~m}$ & $10 \mathrm{D}$ & $3201 \mathrm{kN}$ \\
\hline & $6 \mathrm{D}$ & $7118 \mathrm{kN}$ \\
\hline & $8 \mathrm{D}$ & $14381 \mathrm{kN}$ \\
\hline $3 \mathrm{~m}$ & $10 \mathrm{D}$ & $24625 \mathrm{kN}$ \\
\hline & $6 \mathrm{D}$ & $23625 \mathrm{kN}$ \\
\hline
\end{tabular}

* Main model diameter (planned) are listed though the actual applied diameters differ slightly from integral values.

It is seen from Figure 4.9 to Figure 4.11 that the initial stiffness of the pile head response from the tests are significant lower compared to the standard curves, the difference is approximate a factor of 8-10. Comparison of the ultimate capacity shows a higher measured capacity, equal to a factor of approximately 1.4 . 
The standard curves exhibit a general relative stiffer response, where the standard loaddisplacement curves have a larger curvature for the $25 \%$ of the bearing capacity.

The initial part of the load-displacement curves are presented in Figure 4.12. This figure shows that the standard curves in general have the same behaviour as observed from the tests, though the distribution and mutual relation between diameters are different, with a smaller effect of diameter and embedment length than observed in the tests.

The normalisation of each curve with ultimate capacity and corresponding deformation is presented in Figure 4.13. It is apparent from this figure that the general behaviour of the standard loaddisplacement curves is different from the measured response. The normalised curves show a relative stiffer response than observed in the tests and a difference in the mutual distribution of the different normalised curves.

The evident conclusion is that the standard $p-y$ curves and the applied Winkler theory do not consider the rigid behaviour of the piles. This is a consequence of the general difference in pile behaviour for the present tested piles and the piles originally tested from which the $p-y$ curves are derived.

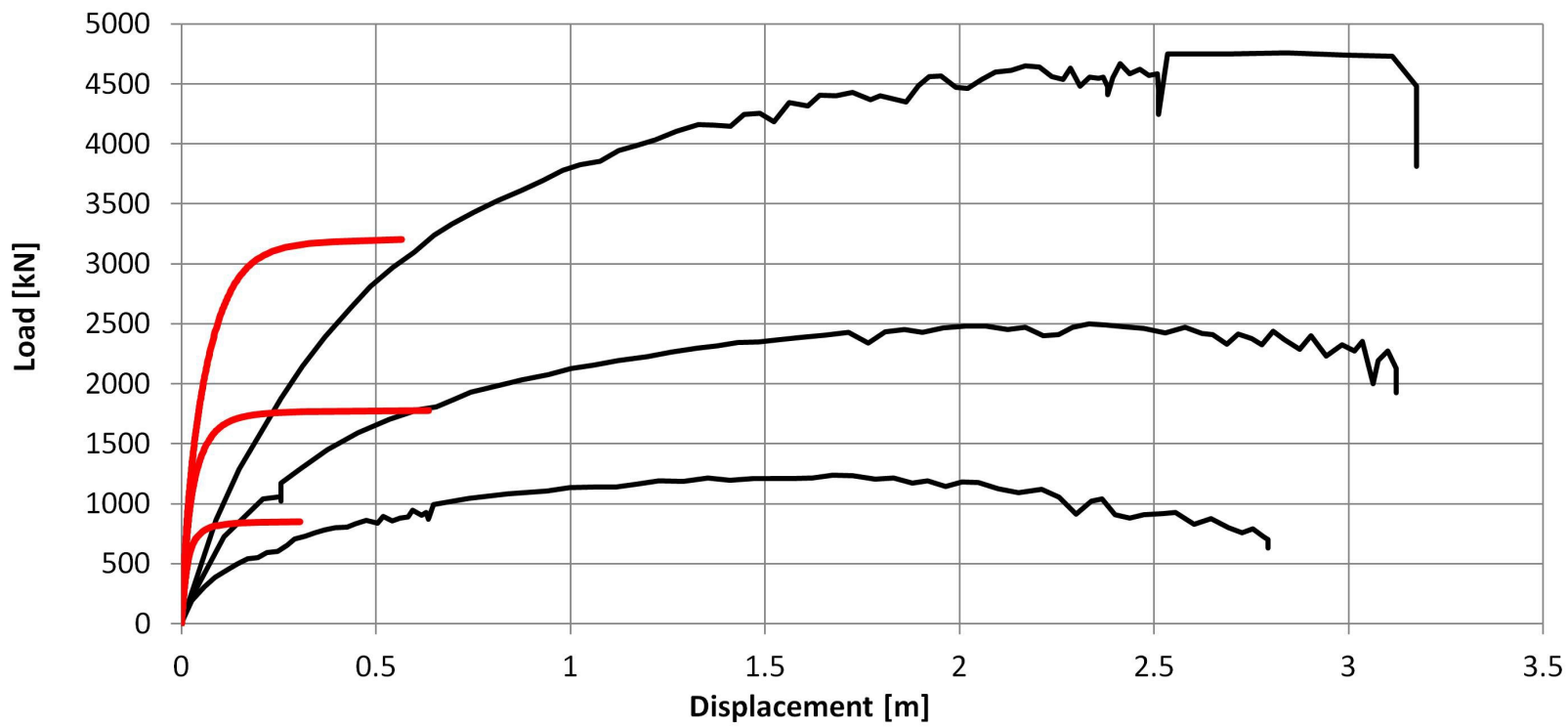

Figure 4.9 Measured (black) and standard (red) load-deflection curve for pile with $D=16 \mathrm{~mm}, L=6 D-8 D-10 D$ and $e=2.5 D$. Prototype scale. 


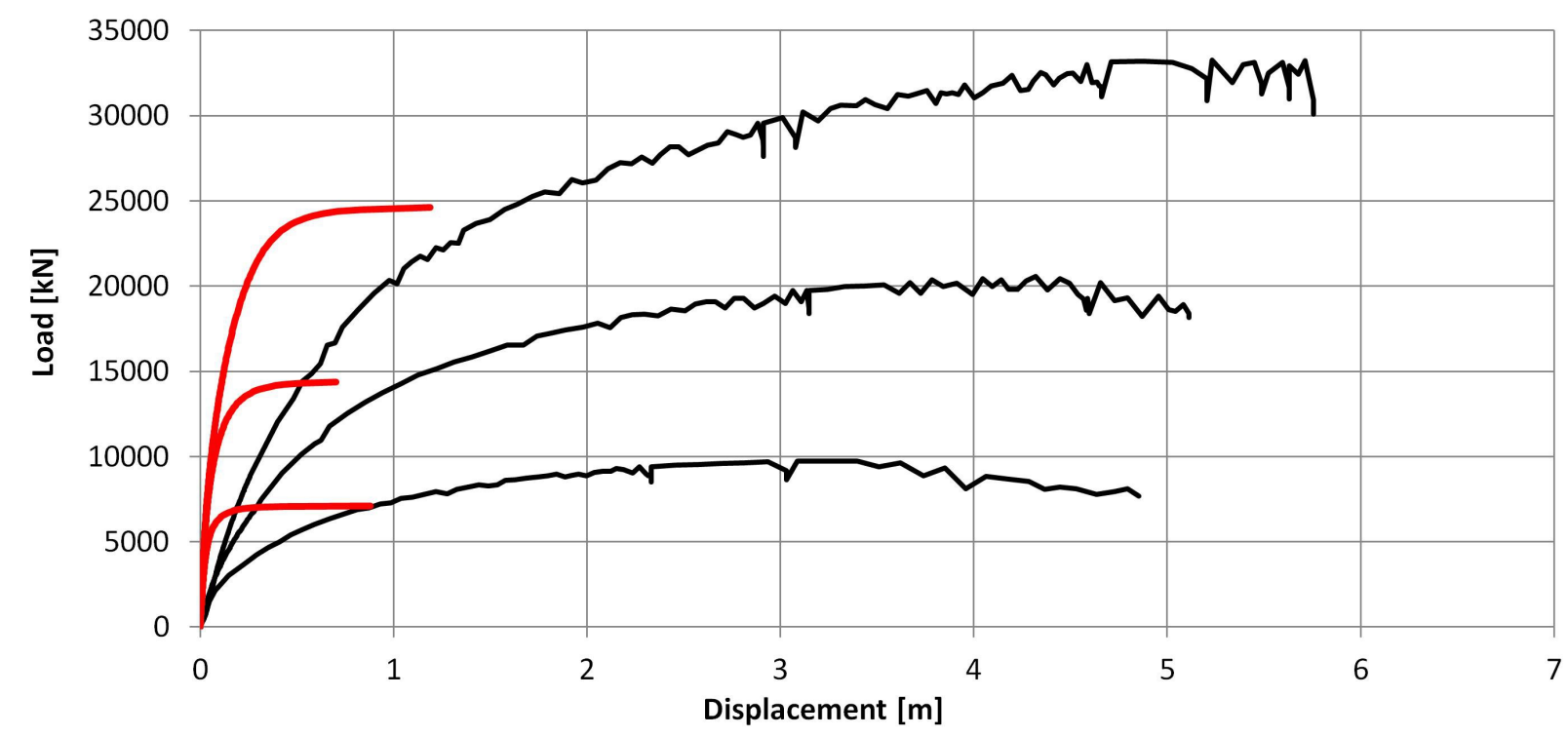

Figure 4.10 Measured (black) and standard (red) load-deflection curve for pile with $D=28 \mathrm{~mm}, L=6-D-8 D-10 D$ and $e=1.43 D$. Prototype scale.

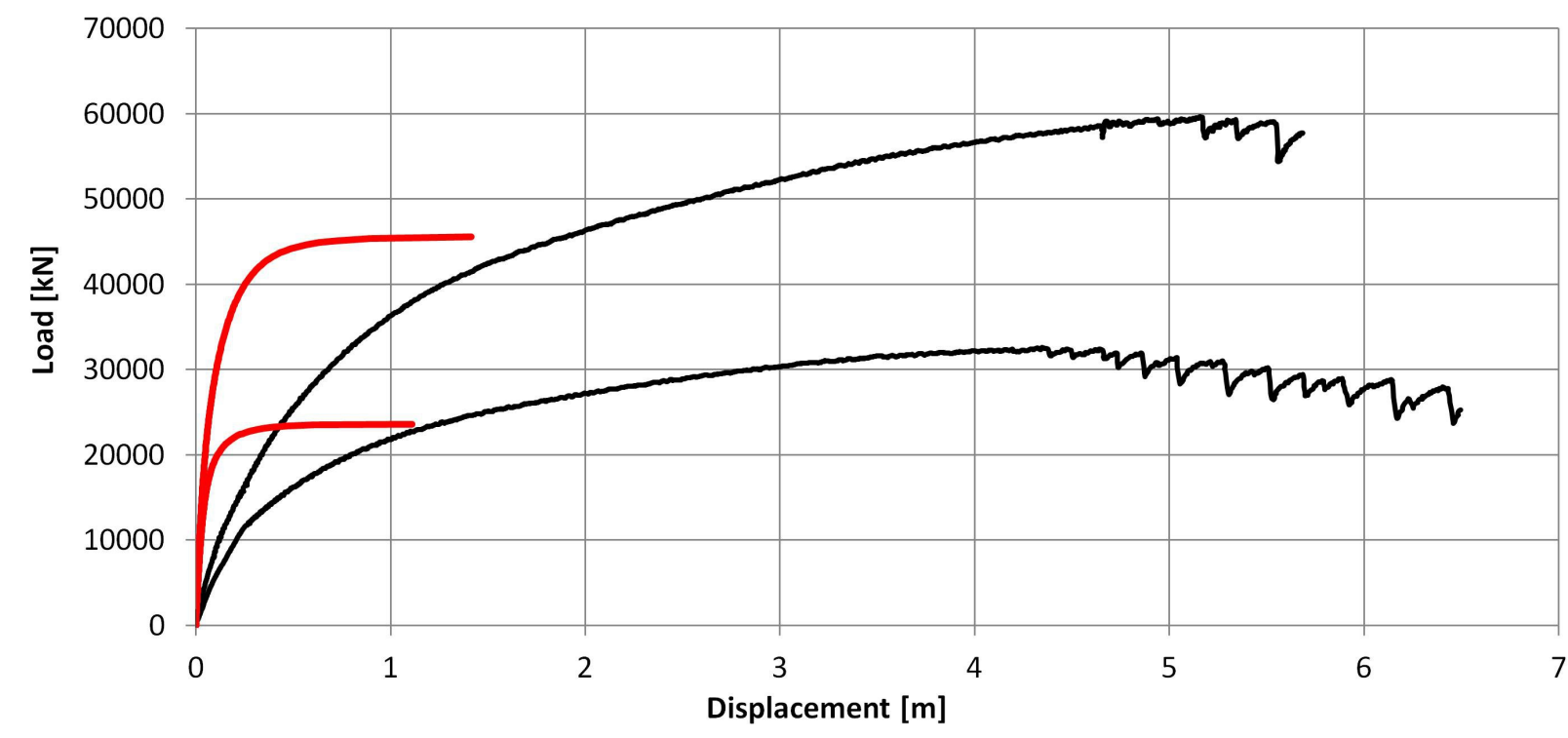

Figure 4.11 Measured (black) and standard (red) load-deflection curve for pile with D=40mm, $L=6 D-8 D$ and $e=1 D$. Prototype scale. 


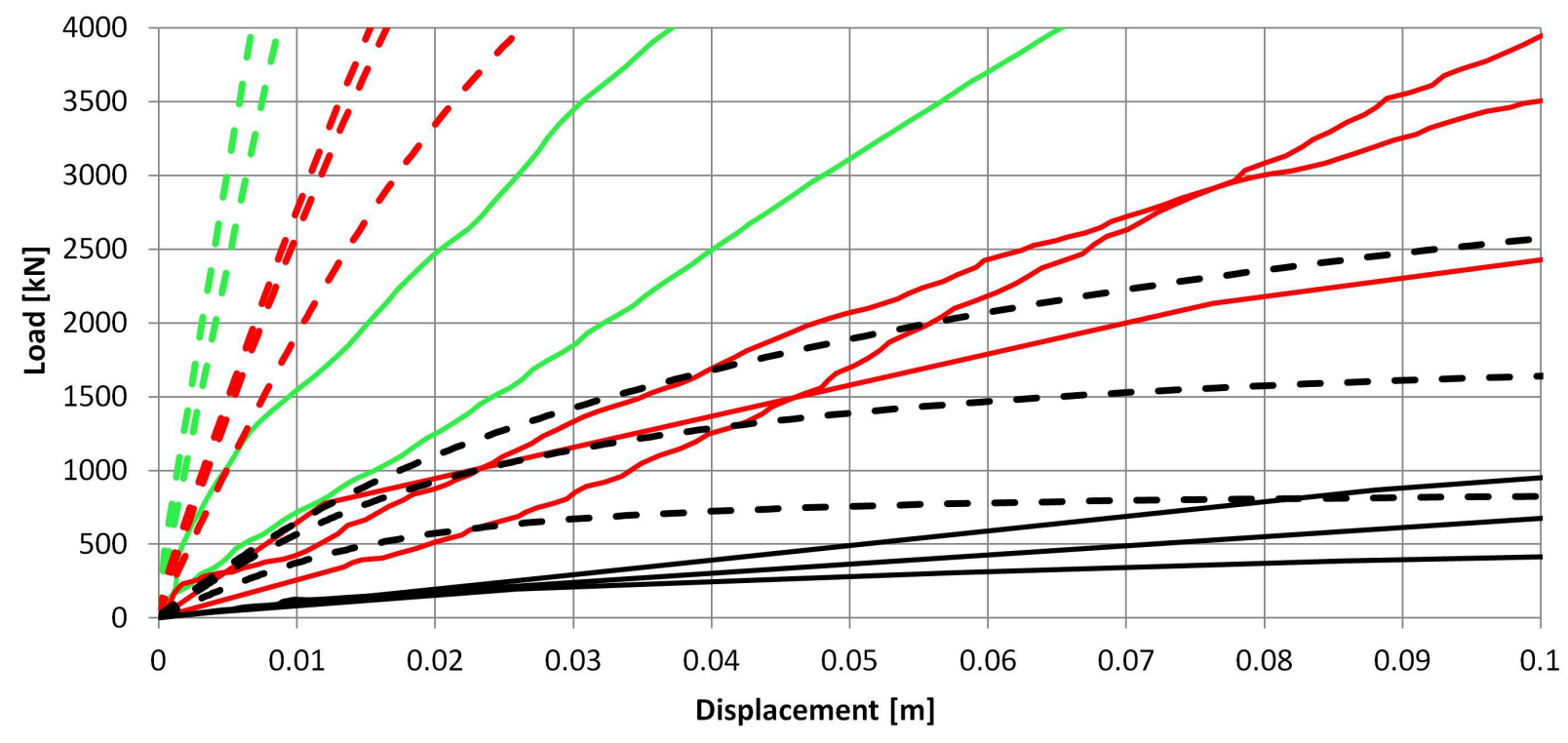

Figure 4.12 Initial part of measured (solid lines) and standard (dashed lines) load-deflection curves for tested piles. $D=1 m$ is black, $D=2 m$ is red and $D=3$ is green.

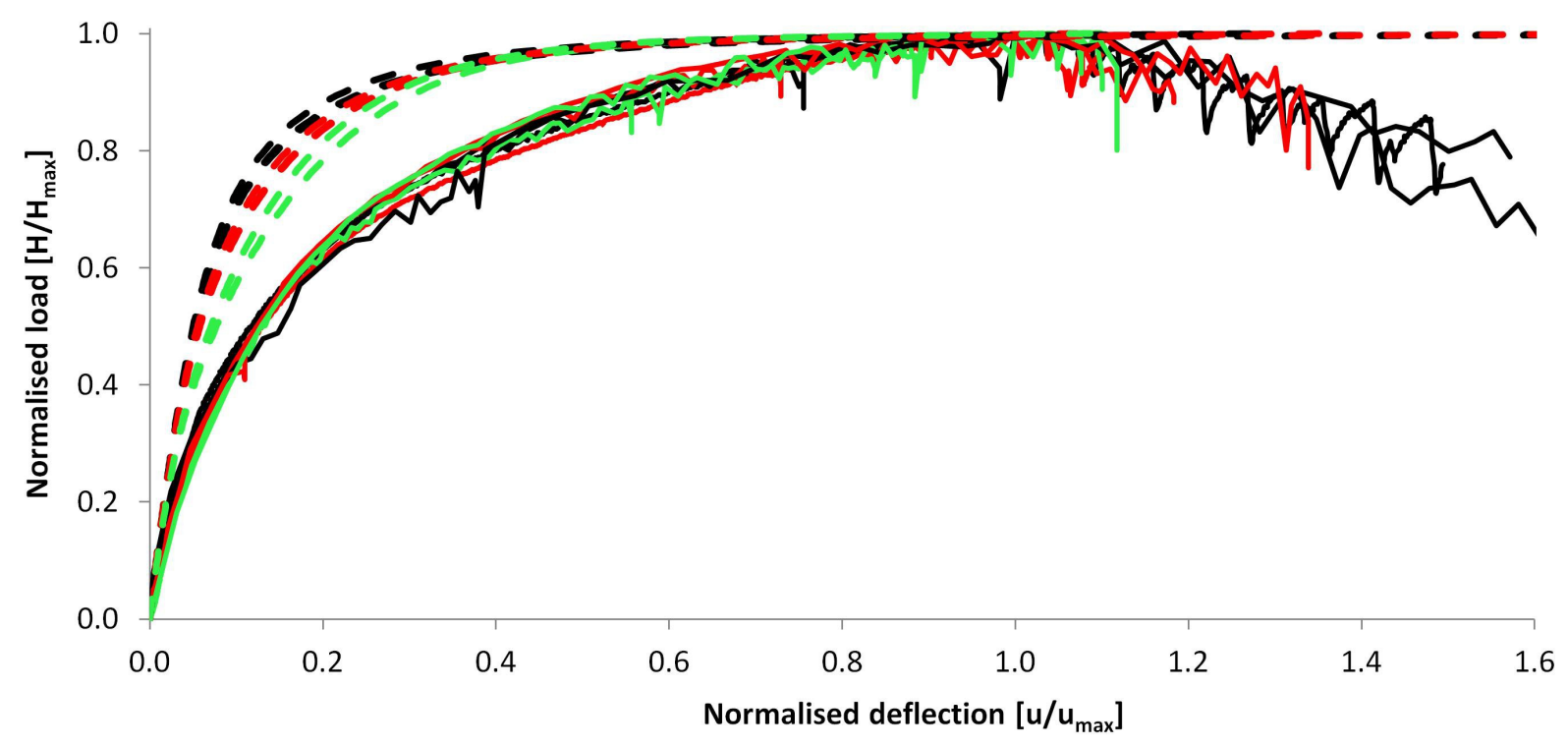

Figure 4.13 Normalised measured (solid lines) and standard (dashed lines) load-deflection curves for tested piles. $D=1 m$ is black, $D=2 m$ is red and $D=3$ is green.

The ratio of the measured / predicted ultimate pile resistance (resistance ratio) is provided in Table 4.5. Considering the variation of the void ratio for the applied samples in the test, Table 4.2, it is seen that there is some dependency of the load height and/or the pile diameter.

The influence from the diameter on the resistance ratio is shown in Figure 4.14. The figure shows a decreasing difference in pile resistance with increasing diameter. There is some deviation with pile length, which indicates different pile response with depth than predicted by standard $p-y$ curves. 


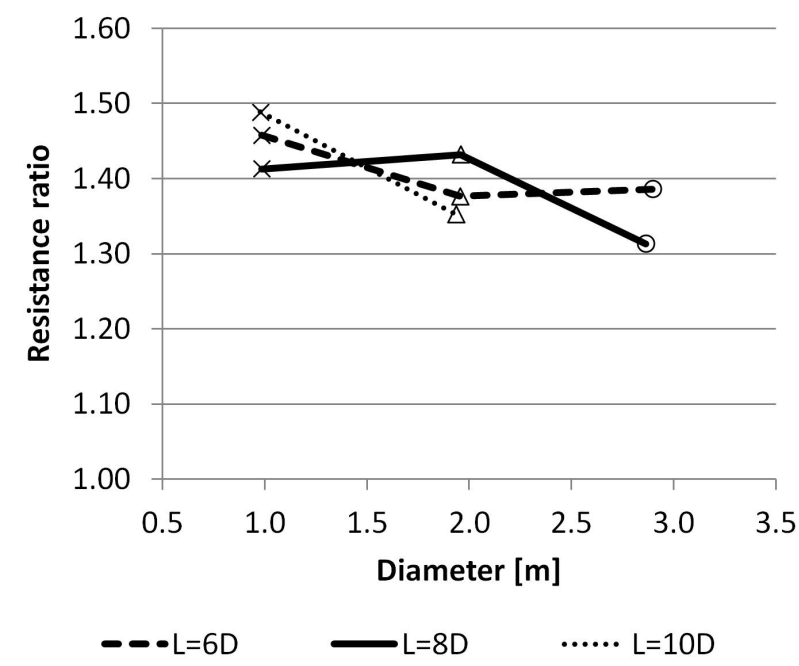

Table 4.5 Resistance ratio (measured/predicted ultimate pile resistance) of piles with varying diameter.

\begin{tabular}{|c|c|}
\hline $\begin{array}{c}\text { Pile setup } \\
\text { D/L/e }\end{array}$ & Resistance ratio \\
\hline $1 \mathrm{~m} / 6 \mathrm{D} / 2.5 \mathrm{D}$ & 1.46 \\
$1 \mathrm{~m} / 8 \mathrm{D} / 2.5 \mathrm{D}$ & 1.41 \\
$1 \mathrm{~m} / 10 \mathrm{D} / 2.5 \mathrm{D}$ & 1.49 \\
\hline $1 \mathrm{~m} / 6 \mathrm{D} / 1.43 \mathrm{D}$ & 1.38 \\
$2 \mathrm{~m} / 8 \mathrm{D} / 1.43 \mathrm{D}$ & 1.43 \\
$2 \mathrm{~m} / 10 \mathrm{D} / 1.43 \mathrm{D}$ & 1.35 \\
\hline $3 \mathrm{~m} / 6 \mathrm{D} / 1 \mathrm{D}$ & 1.39 \\
$3 \mathrm{~m} / 8 \mathrm{D} / 1 \mathrm{D}$ & 1.31 \\
\hline
\end{tabular}

Figure 4.14 Pile diameter vs. resistance ratio (measured/standard).

\subsection{Ultimate bearing capacity}

The ultimate bearing capacity from the static piles is underestimated by the standard curves, which primary is explained by a different behaviour of the piles and mobilization of the soil. (Capacities are given are given in Table 4.6).

The standard curves are based on a fixity of the pile in the soil where the flexibility of the pile influences the deformation, whereas the experimental behaviour is rigid with a a general rotational behaviour and a single point of no deflection.

A method for calculating the bearing capacity of rigid piles has been proposed by Hansen (1961). This method is based on earth pressure theory and rotation around a point on the lower part of the pile. Comparison with this method reveals that the theoretical method underestimates the capacity by $40 \%$. The calculated capacities are given in Table 4.6. The applied earth pressure in Hansen (1961) is assumed to increase with depth from surface to tip of pile with a change in sign at the point of rotation, see Figure 4.15.

It is questionable if the soil will be fully mobilized near the point of rotation, and an

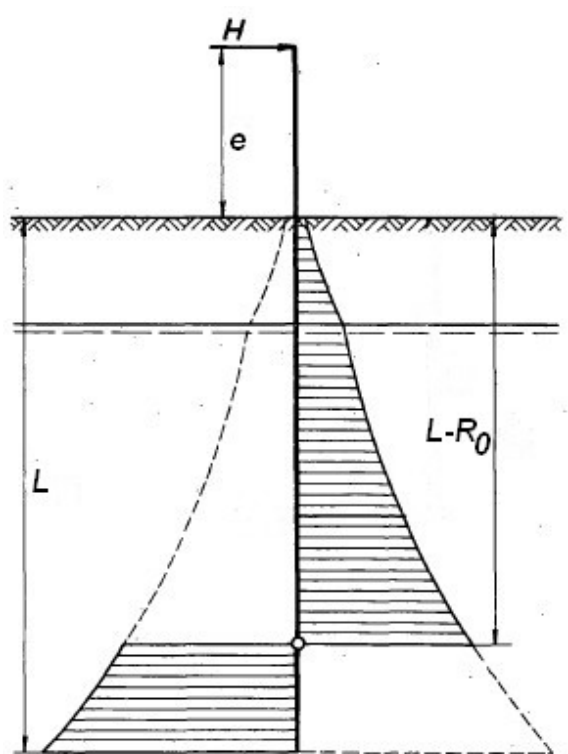

Figure 4.15 Earth pressure distribution according to Hansen (1961), with nomenclature according to present thesis. 
overestimated earth pressure near the point of rotation will lead to overestimated ultimate capacities, which is opposite to what is observed.

Considering the rotational behaviour of the pile and the background for both the standard curves and the method applied by Hansen (1961) it is apparent that neither of the theoretical methods consider the "toe kick", the displacement of the pile tip, and the forces acting on the pile from this effect. The forces acting on the tip of the pile from a "toe kick" mechanism will have a stabilizing effect and thus increase the bearing capacity. Further research is necessary to measure the rotation and investigate the "toe kick" effect.

Table 4.6 Ultimate capacities of monopiles based on a) measured data, standard curves and Hansen (1961).

\begin{tabular}{|l|l|l|l|l|}
\hline Diameter (D) & $\begin{array}{l}\text { Embedment } \\
\text { length }[\mathrm{m}]\end{array}$ & $\begin{array}{l}\text { Measured } \\
{[\mathrm{kN}]}\end{array}$ & $\begin{array}{l}\text { Standard curvs } \\
{[\mathrm{kN}]}\end{array}$ & $\begin{array}{l}\text { Hansen (1961) } \\
{[\mathrm{kN}]}\end{array}$ \\
\hline 1 & 6 & 1236 & 851 & 775 \\
\hline 1 & 8 & 2498 & 1777 & 1590 \\
\hline 1 & 10 & 4759 & 3201 & 2735 \\
\hline 2 & 6 & 9744 & 7118 & 6340 \\
\hline 2 & 8 & 20567 & 14381 & 12625 \\
\hline 2 & 10 & 33253 & 24625 & 20600 \\
\hline 3 & 6 & 32576 & 23625 & 20820 \\
\hline 3 & 8 & 59653 & 45590 & 39500 \\
\hline
\end{tabular}




\subsection{Evaluation of initial stiffness}

The initial part of the normalised load-deflection curve, Figure 4.13, is enlarged in Figure 4.17.

The initial pile head stiffness, definition shown in Figure 4.16, from the centrifuge tests and the standard pile response is given in Table 4.7. The initial stiffness is determined for a normalised displacement $\left(u / u_{\max }\right)$ of 0.01 for the load deflection curves obtained from the tests and the standard curves. The results presented shows some dependency of diameter and embedment length.

It is noted that the initial pile head stiffness for the three piles with a diameter of $2 \mathrm{~m}$ seems wrong. Applying a normalised displacement of 0.01 for the three curves in question equals a displacement of $0.03,0.04$ and $0.05 \mathrm{~m}$, respectively. Figure 4.12 shows that the initial

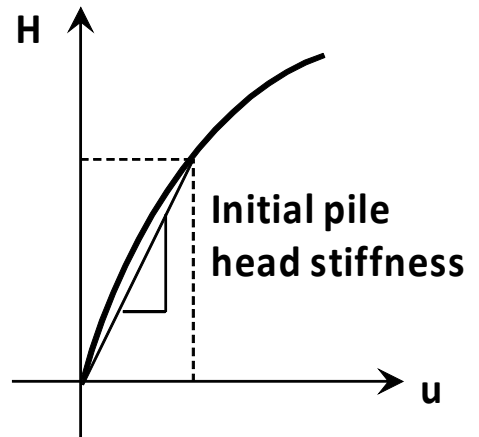

Figure 4.16 Definition of initial tangent pile head stiffness.

Table 4.7 Initial pile head stiffness.

\begin{tabular}{|c|c|c|c|}
\hline Pile setup & \multicolumn{3}{|c|}{ Initial pile head stiffness } \\
D/L/e & Test $[\mathrm{kPa}]$ & Standard [kPa] & Ratio \\
\hline $1 \mathrm{~m} / 6 \mathrm{D} / 2.5 \mathrm{D}$ & 7,788 & 44,333 & 0.18 \\
$1 \mathrm{~m} / 8 \mathrm{D} / 2.5 \mathrm{D}$ & 8,614 & 64,228 & 0.13 \\
$1 \mathrm{~m} / 10 \mathrm{D} / 2.5 \mathrm{D}$ & 9,740 & 70,263 & 0.14 \\
\hline $2 \mathrm{~m} / 6 \mathrm{D} / 1.43 \mathrm{D}$ & 38,076 & 205,607 & 0.19 \\
$2 \mathrm{~m} / 8 \mathrm{D} / 1.43 \mathrm{D}$ & 42,499 & 270,224 & 0.16 \\
$2 \mathrm{~m} / 10 \mathrm{D} / 1.43 \mathrm{D}$ & 34,886 & 273,921 & 0.13 \\
\hline $3 \mathrm{~m} / 6 \mathrm{D} / 1 \mathrm{D}$ & 62,452 & 471,450 & 0.13 \\
$3 \mathrm{~m} / 8 \mathrm{D} / 1 \mathrm{D}$ & 100,788 & 570,167 & 0.18 \\
\hline
\end{tabular}
part of the measured load-displacement curves for the piles with a diameter of $2 \mathrm{~m}$ are a bit strange and probably defective. It is based on further investigation of the load-displacement curves assessed that the initial part of the curve for a pile with a diameter of $2 \mathrm{~m}$ and an embedment length of $6 D$ and $10 D$ are defective and are thus applied in the following evaluation of the initial stiffness.

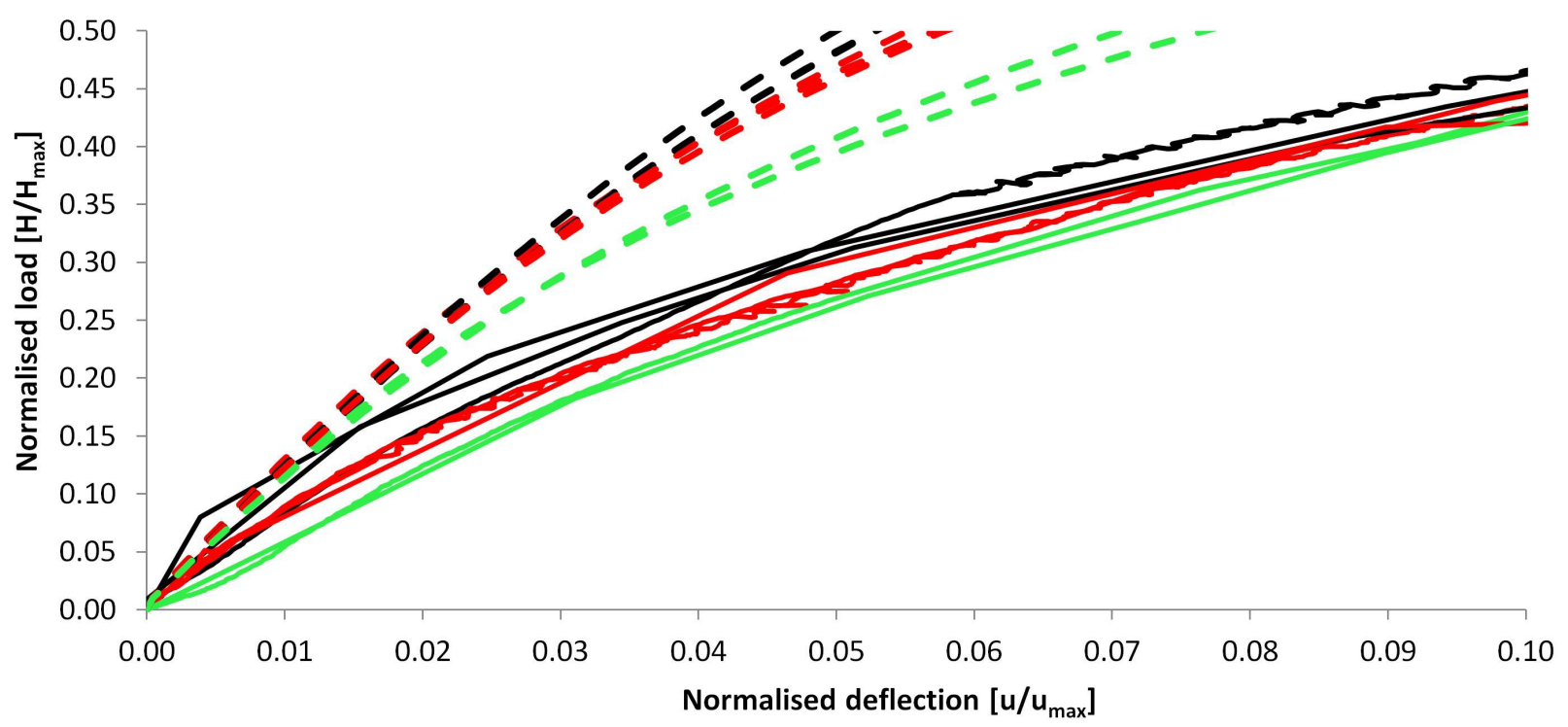

Figure 4.17 Initial pile head stiffness, enlarged part of Figure 4.13. 
The initial stiffness of the standard $p-y$ curves increases linear with depth, cf. Figure 2.6. Results from several research projects indicates different distributions, Achmus et al. (2007), Augustesen et al. (2010), Barton et al. (1983), Georgiadis et al. (1992), Lesny \& Wiemamm (2006), Pender et al. (2007) and Sørensens et al. (2010). Analyses of numerical models by Sørensen et al. (2010) indicate that the initial stiffness depends on the depth $x$, diameter $D$ and internal friction angle $\phi_{\text {described }}$ by a power function. The equation described by Sørensen et al. (2010) is rewritten to depend on depth and diameter:

$$
E_{p y, i n i}=a \cdot\left(\frac{x}{x_{r e f}}\right)^{b} \cdot\left(\frac{D}{D_{r e f}}\right)^{c}
$$

Where $b$ and $c$ are dimensionless constants, $a$ is a factor specifying the initial stiffness for the reference situation, $x_{r e f}$ and $D_{r e f}$ is the reference diameter and depth ( $1 \mathrm{~m}$ is applied for both). The part of the original equation describing the dependency of the friction angle is here included in the factor $a$ as only one sample density is applied in the presented centrifuge tests.

The test piles are assessed to behave rigid at initial loading with only elastic deformations in the sand. The pile displacement can then be determined from the rotation and the pile head displacement $u$ (see Figure 3.25 for basic pile definitions):

$$
y(x)=u-\theta \cdot(e+x)
$$

The initial reaction from the soil is then described by:

$$
p(x)=E_{p y, i n i}(x) \cdot y(x)
$$

Based on moment equilibrium at pile head and horizontal equilibrium following relation can be derived:

$$
\frac{H}{u}=a \cdot D^{c} \cdot \frac{1}{b+2} \cdot \frac{L^{b} \cdot L^{3}}{(b+2)(b+3) e^{2}+(b+1)(b+3) 2 \cdot e \cdot L+(b+1)(b+2) L^{2}}
$$

Where $H$ is the horizontal force, $u$ is pile head displacement, $L$ is pile length, $e$ is load height, $a, b$ and $c$ are constants.

Application of an initial stiffness increasing linear with depth, $E_{p y, i n i}=k \cdot x$, following equation can be derived:

$$
\frac{H}{u}=k \cdot \frac{1}{6} \cdot \frac{L^{4}}{6 \cdot e^{2}+8 \cdot e \cdot L+3 \cdot L^{2}}
$$

The constants in equation (4.1) are determined by applying equation (4.4) to the initial pile head stiffness given in Table 4.7 and employing best fit:

$$
E_{p y, \text { ini }}=6475 \cdot\left(\frac{x}{1 m}\right)^{0.5} \cdot\left(\frac{D}{1 m}\right)^{0.6} \quad\left[\frac{\mathrm{kN}}{\mathrm{m}} / \mathrm{m}\right]
$$


The initial pile head stiffnesses from the centrifuge tests (from Table 4.7) are plotted in

Figure 4.18 Initial pile head stiffness, predicted vs. Figure 4.18 along with the initial stiffness measured.

calculated by use of equation (4.4). The

expression for initial stiffness produces a very

good fit, except for the two values omitted in the fitting ( $D=2 m$ and $L=6 D \& L=8 D)$. The presented fit has a coefficient of determination of $R^{2}=0.996$

Comparing the power coefficients with the results described in Augustesen et al. (2010), shows slightly changed values, with a present slightly reduced dependency with depth (power of $x$ is reduced from 0.6 to 0.5 ) and a slightly higher dependency on diameter (power of $D$ is increased from 0.5 to 0.6 ). It is noted that the dependency with depth, square root, follows the findings of among other Barton et al. (1983).

\subsection{Summary static behaviour}

The general static behaviour of monopiles in dry sand has, based on centrifuge tests, been investigated. The main focus has been on initial stiffness and pile capacity.

The conclusions regarding static behaviour are:

- The general behaviour of rigid piles is not described properly by standard curve and exhibit a general smoother response towards failure than predicted.

- The standard $p-y$ curves underestimates the pile capacity, the difference is inverse proportional to the diameter.

- The standard $p-y$ curves overestimate the pile-soil stiffness for large diameter rigid piles.

- The initial stiffness of the $p-y$ curves depends on the depth below surface and diameter of the pile, with a power dependency for each factor - the stiffness varies with the square root of the depth. 


\section{Cyclic behaviour}

\subsection{Overview}

A total of 9 cyclic tests have been carried out as a part of the present research, and the cyclic test program is presented in Table 5.1. Applied load and pile head displacements have been measured throughout the tests.

The cyclic tests have been carried out as load controlled tests and consists, as generally outlined in section 3.5.2, of five parts:

Table 5.1 Cyclic test program, model pile dimensions.

\begin{tabular}{|c|c|c|c|c|}
\hline $\mathrm{D}$ & $\mathrm{L}=6 \mathrm{D}$ & $\mathrm{L}=8 \mathrm{D}$ & $\mathrm{L}=10 \mathrm{D}$ & $\mathrm{e}$ \\
\hline $16 \mathrm{~mm}$ & 1 & 1 & 1 & $2.5 \mathrm{D}$ \\
\hline $28 \mathrm{~mm} *$ & 2 & 1 & 1 & $1.429 \mathrm{D}$ \\
\hline $40 \mathrm{~mm}^{* *}$ & 1 & 1 & $\mathrm{NA}$ & $1 \mathrm{D}$ \\
\hline
\end{tabular}

* Two series of tests with identical load specifications.

** 2 cyclic tests have been carried out by the laboratory personel at DTU.BYG (Klinkvort 2009b)

- Initial loading to $1 / 4$ of ultimate static capacity (USC).

- Three cyclic series, each with 100 cycles:

- 100 cycles with an average load of $1 / 4$ of USC and an amplitude of $1 / 4$ of the USC.

- 100 cycles with an average load of $1 / 4$ of USC and an amplitude of $1 / 8$ of the USC.

- 100 cycles with an average load of 1/4 of USC and an amplitude of $1 / 4$ of the USC.

- Static loading until failure.

To investigate the repeatability two cyclic tests with same load specifications have been carried out on a model pile with a diameter of $28 \mathrm{~mm}$ and an embedment length of $6 D$.

Relative densities for the samples applied in the cyclic test series are presented in Table 5.2.

The presented results are measured values and not scaled to prototype scale according to the scaling principles described in section 2.4.2. The results are presented with further details in Leth (2011).

It is noted that Leth (2011), has a misprint in Appendix B "Results from lateral load tests" - all the results from cyclic load tests presented in the report are not scaled which is contrary to what is written in the appendix.
Table 5.2 Relative densities for samples applied to the cyclic tests.

\begin{tabular}{|c|c|c|c|}
\hline $\mathrm{D}$ & $\mathrm{L}=6 \mathrm{D}$ & $\mathrm{L}=8 \mathrm{D}$ & $\mathrm{L}=10 \mathrm{D}$ \\
\hline $16 \mathrm{~mm}$ & 0.847 & 0.828 & 0.820 \\
\hline $28 \mathrm{~mm}$ & $0.828 / 0.862$ & 0.814 & 0.811 \\
\hline $40 \mathrm{~mm}$ & 0.834 & 0.884 & NA \\
\hline
\end{tabular}




\subsection{Test results}

\subsubsection{Cyclic tests on piles with a diameter of $16 \mathrm{~mm}$}

The load-displacement curves for the three cyclic tests on model piles with a diameter of $16 \mathrm{~mm}$ are shown in Figure 5.1 to Figure 5.3. The figures also includes the equivalent static tests which are presented with a dashed black line.

It is evident from Figure 5.1 to Figure 5.3 that:

- The load control is relative poor as the amplitude of the load cycles changes through the first and third cyclic series.

- Maximum of the applied load cycles in the first load series seems to be limited by the static capacity.

- The post cyclic behaviour of the pile is stiffer compared to the static response. This is interpreted as a result of the compaction around the pile which will take place when the pile is subject to relative large cyclic loads.

- The ultimate capacity is increased

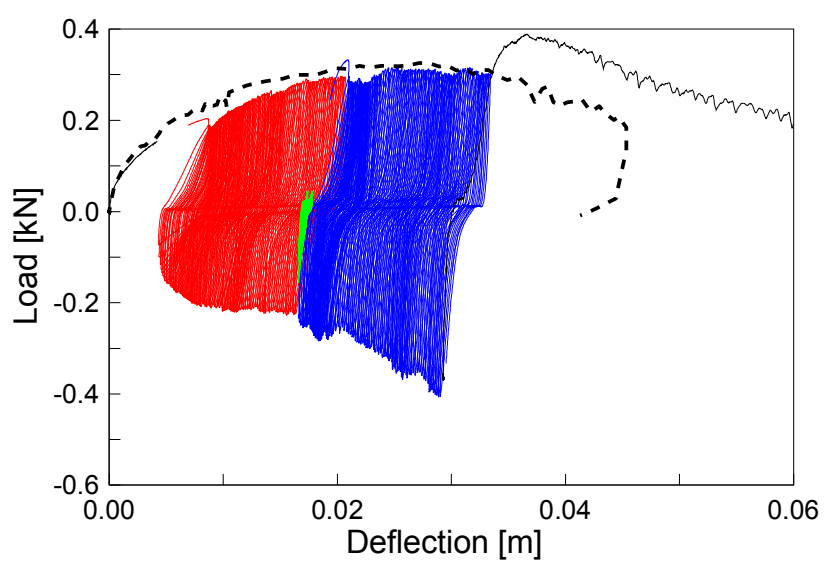

Figure 5.1 Measured load-displacement curve for cyclic test on pile with $D=16 \mathrm{~mm}, L=6 D$, $e=2.5 D$.

Equivalent static test is shown with dashed black line.

following the cyclic load series.
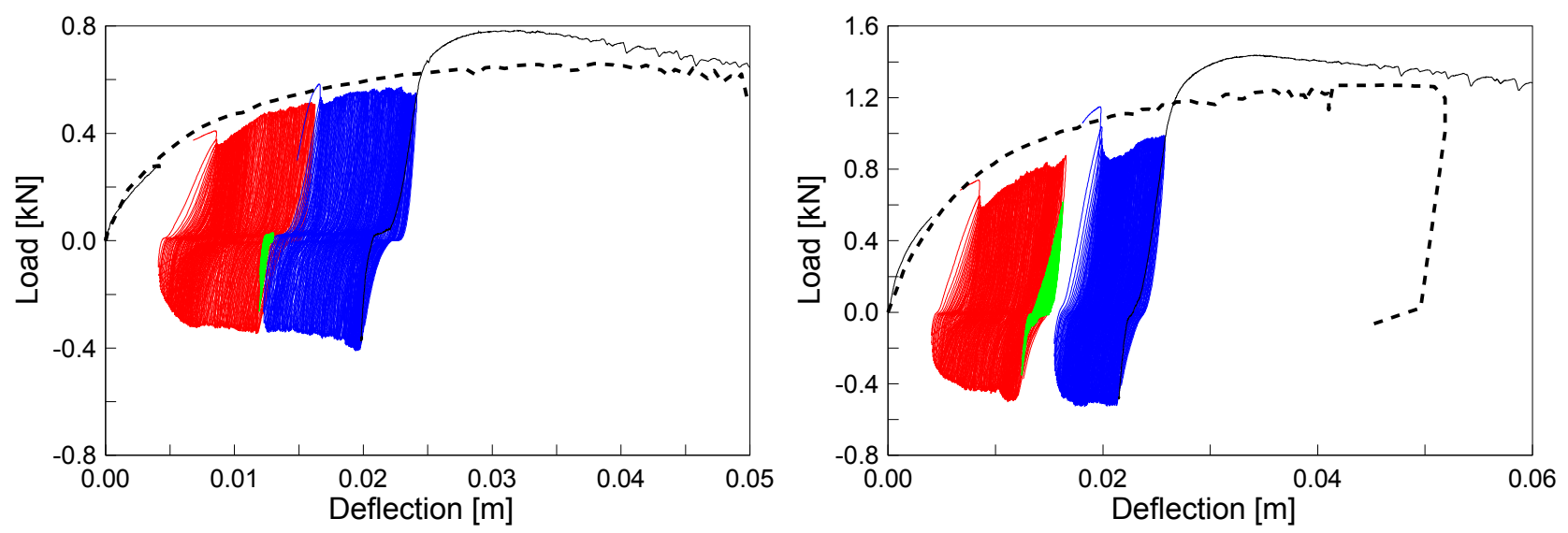

Figure 5.2 Measured load-displacement curve for cyclic test on pile with $D=16 \mathrm{~mm}, L=8 D$, $e=2.5 D$.

Equivalent static test is shown with dashed black line.

Figure 5.3 Measured load-displacement curve for cyclic test on pile with $D=16 \mathrm{~mm}, L=10 \mathrm{D}$, $e=2.5 D$.

Equivalent static test is shown with dashed black line. 
The measured load-displacement curves presented in Figure 5.1 to Figure 5.3 have been analysed and curves for the average displacement and secant stiffness vs. load cycle have been created, see Figure 5.4 to Figure 5.6.

It is observed from Figure 5.4 to Figure 5.6:

- The actual control of the test affects directly the accumulation and change in stiffness. This is most evident for the second cyclic load series.

- The average deflection increases, which is interpreted as a consequence of the high load ratio (cyclic loading vs. static load), and increasing load amplitude.

- The secant stiffness increases though it is observed from the few cycles where it is managed to have a constant load amplitude that the stiffness will tend to stabilized and become constant.
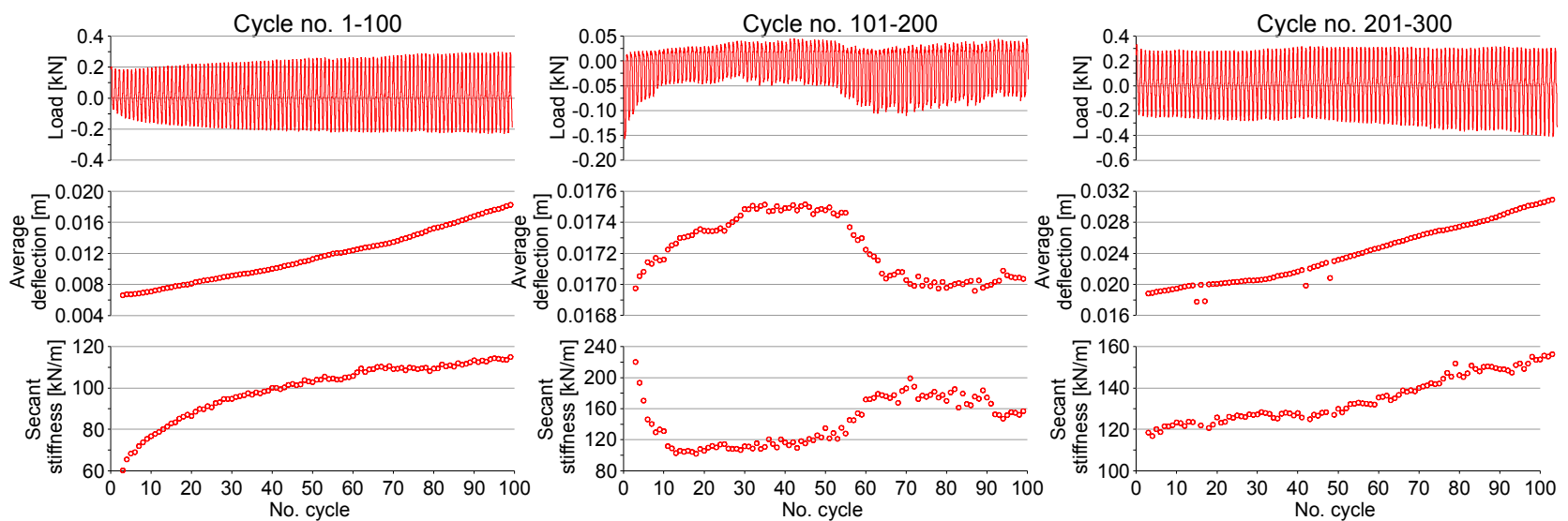

Figure 5.4 Average deflection and secant stiffness vs. number of load cycles for pile with $D=16 \mathrm{~mm}, L=6 D$ and $e=2.5 D$.
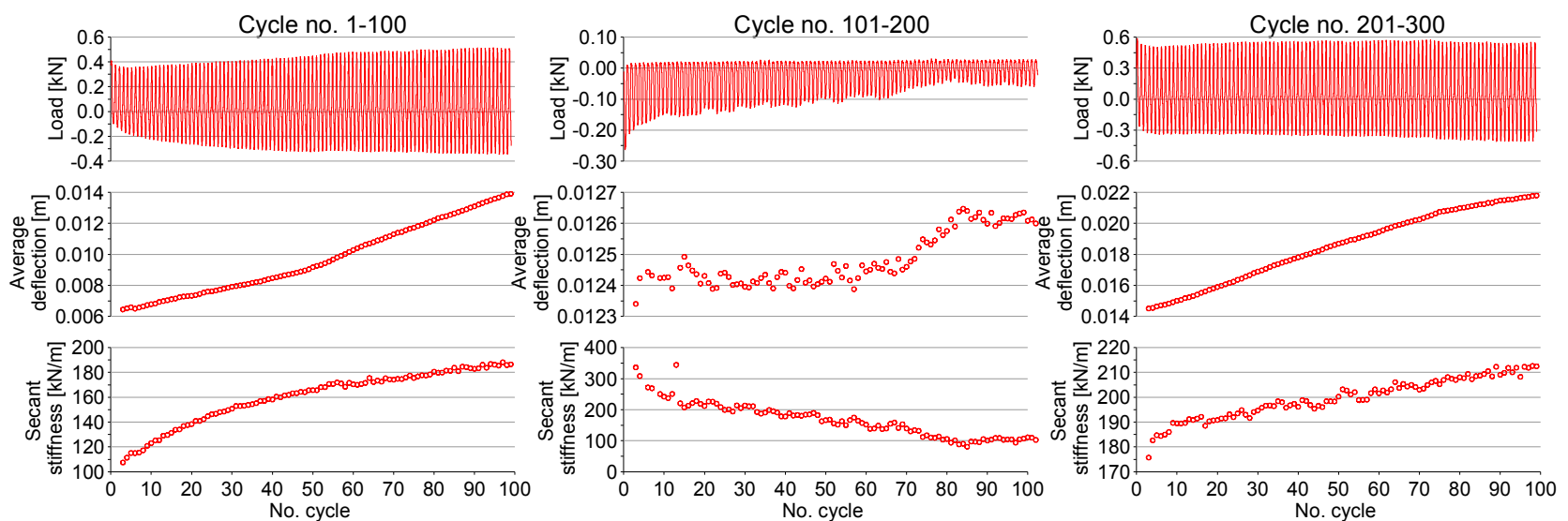

Figure 5.5 Average deflection and secant stiffness vs. number of load cycles for pile with $D=16 \mathrm{~mm}, L=8 D$ and $e=2.5 D$ 

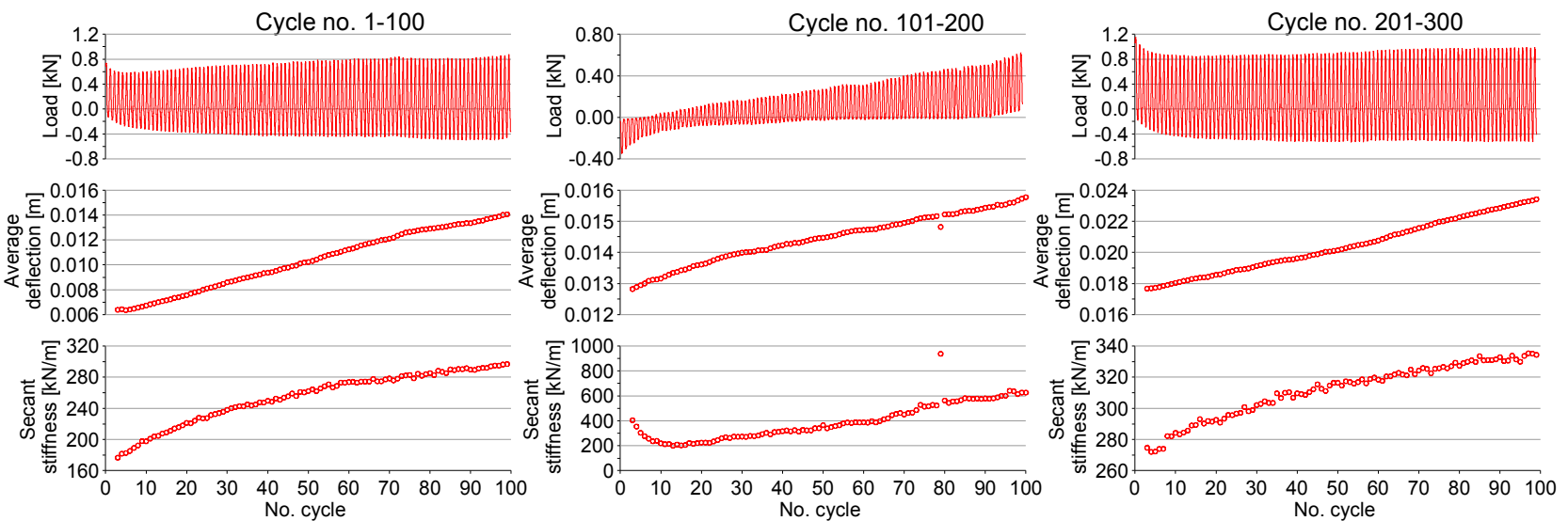

Figure 5.6 Average deflection and secant stiffness vs. number of load cycles for pile with $D=16 \mathrm{~mm}, \mathrm{~L}=10 \mathrm{D}$ and $e=2.5 D$.

\subsubsection{Cyclic tests on piles with a diameter of $28 \mathrm{~mm}$}

Four cyclic tests have been carried out on piles with a diameter of $28 \mathrm{~mm}$ and the measured loaddisplacement curves are presented in Figure 5.7 - Figure 5.10 along with the results from the equivalent static tests (dashed black lines).

The two tests on piles with an embedment length of $6 D$ (Figure 5.7 and Figure 5.8) show a significant difference, and a further investigation into the collected data suggest that an issue with the data logging might have happened with the second test. This second test is omitted in the further assessments.

The measured load-displacement curve for a pile with a diameter of $28 \mathrm{~mm}$ and an embedment length of $6 D$ shows (see Figure 5.7):

- Some issues with the load control as observed in the tests on the piles with a diameter of $16 \mathrm{~mm}$.

- The loading in the first load series seems to be limited by the static capacity, and the load amplitude increases throughout the first and third cyclic load series.

- The initial load cycle of the third cyclic phase shows an increased capacity with a peak in applied load prior to start of the 100 cycles.

- The post cyclic behaviour of the pile is stiffer compared to the static response. This is interpreted as a result of the compaction around the pile which will take place when it is subject to a number of cyclic loads with a high utilisation.

- The ultimate capacity is increased following the three cyclic load series. 
The tests on piles with an embedment length of $8 D$ and $10 D$ shows:

- The amplitude of the applied load is not constant and increases during the first load cyclic series and varies in the third series.

- The applied load is smaller than the static load curve and the post cyclic ultimate capacity is equal to or less than the static capacity.

- The post cyclic behaviour of the pile is stiffer compared to the static response. This is interpreted as a result of the compaction in the vicinity of the pile which will take place when it is subject to relative large cyclic loads.

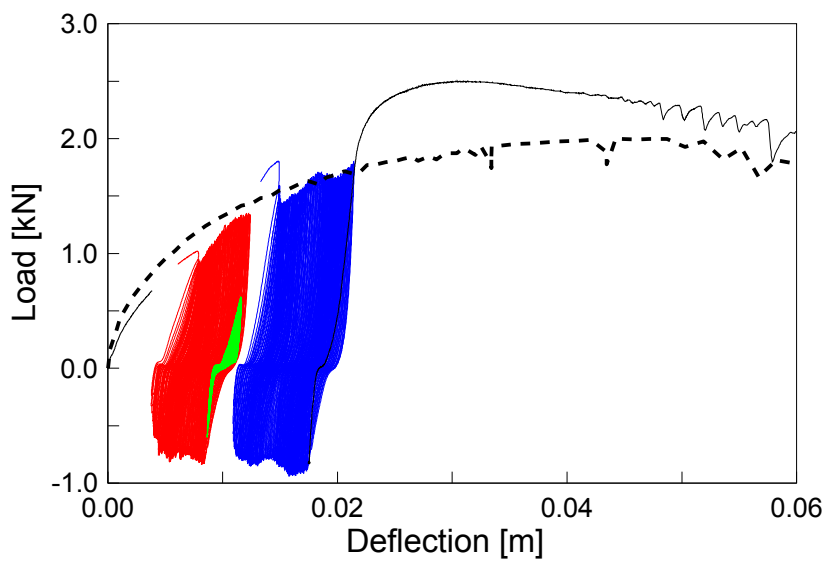

Figure 5.7 Measured load-displacement curve for cyclic test 1 on pile with $D=28 \mathrm{~mm}, L=6 D$, $e=1.43 D$.

Equivalent static test is shown with dashed black line.

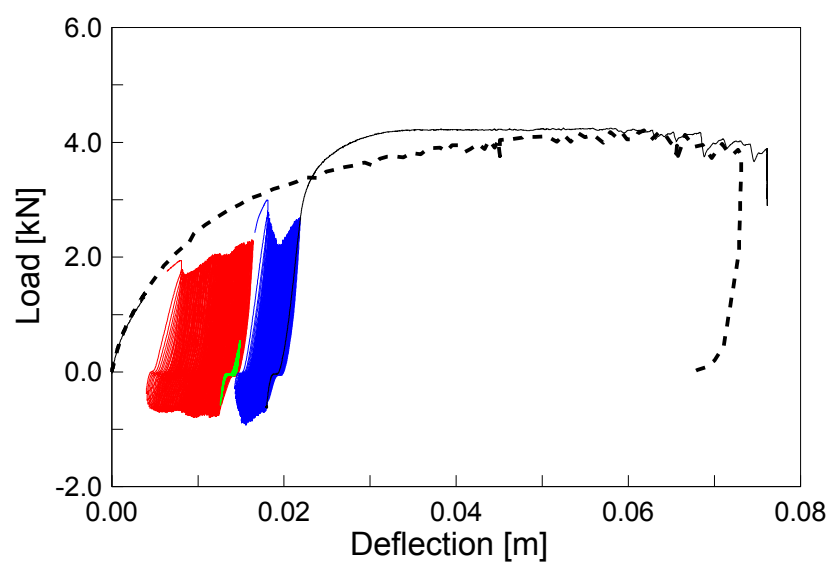

Figure 5.9 Measured load-displacement curve for cyclic test on pile with $D=28 \mathrm{~mm}, L=8 D$, $e=1.43 D$.

Equivalent static test is shown with dashed black line.

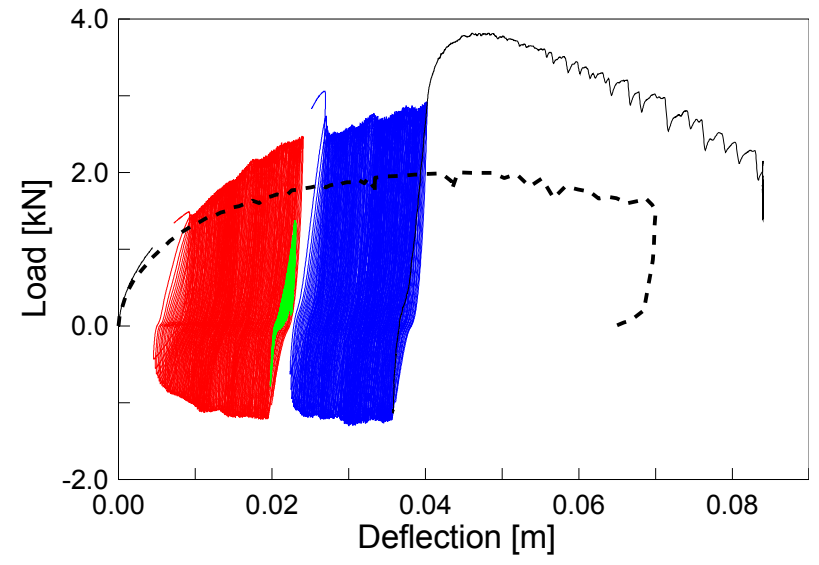

Figure 5.8 Measured load-displacement curve for cyclic test 2 on pile with $D=28 \mathrm{~mm}, L=6 D$, $e=1.43 D$.

Equivalent static test is shown with dashed black line.

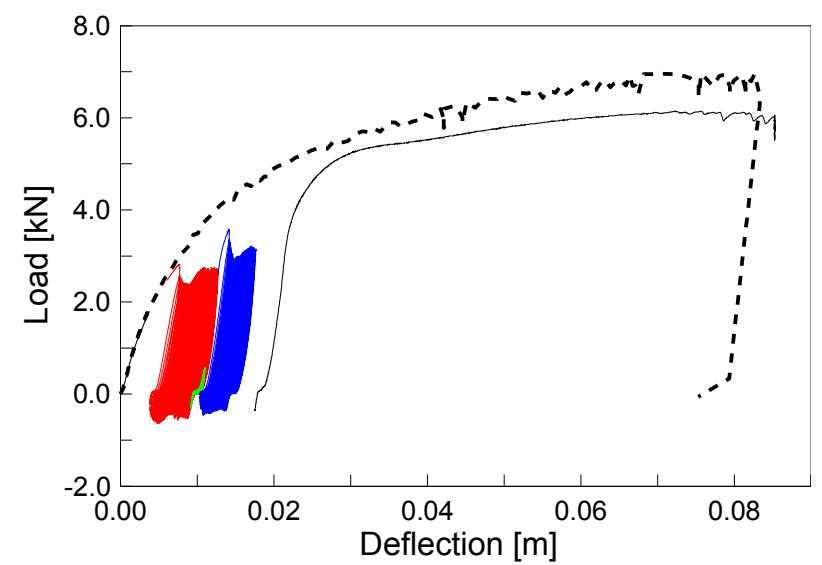

Figure 5.10 Measured load-displacement curve for cyclic test on pile with $D=28 \mathrm{~mm}, L=10 \mathrm{D}$, $e=1.43 D$

Equivalent static test is shown with dashed black line. 
The measured load-displacement curves presented in Figure 5.7, Figure 5.9 and Figure 5.10 have been analysed and curves for the average displacement and secant stiffness vs. load cycle have been plotted in Figure 5.11 to Figure 5.13.

Following is observed from Figure 5.11 to Figure 5.13:

- The control of the test affects the accumulation and change in stiffness. This is most evident for the second cyclic load series.

- The average deflection increases for the first and third cyclic load series, which is interpreted as a consequence of the high load ratio (cyclic loading vs. static load), and the control issues with increasing load amplitude.

- The secant stiffness increases though it is observed from the cycles where it is managed to have a constant load amplitude (later part of first and third series of $L=10 D$ ) that the stiffness will stabilized and become constant.
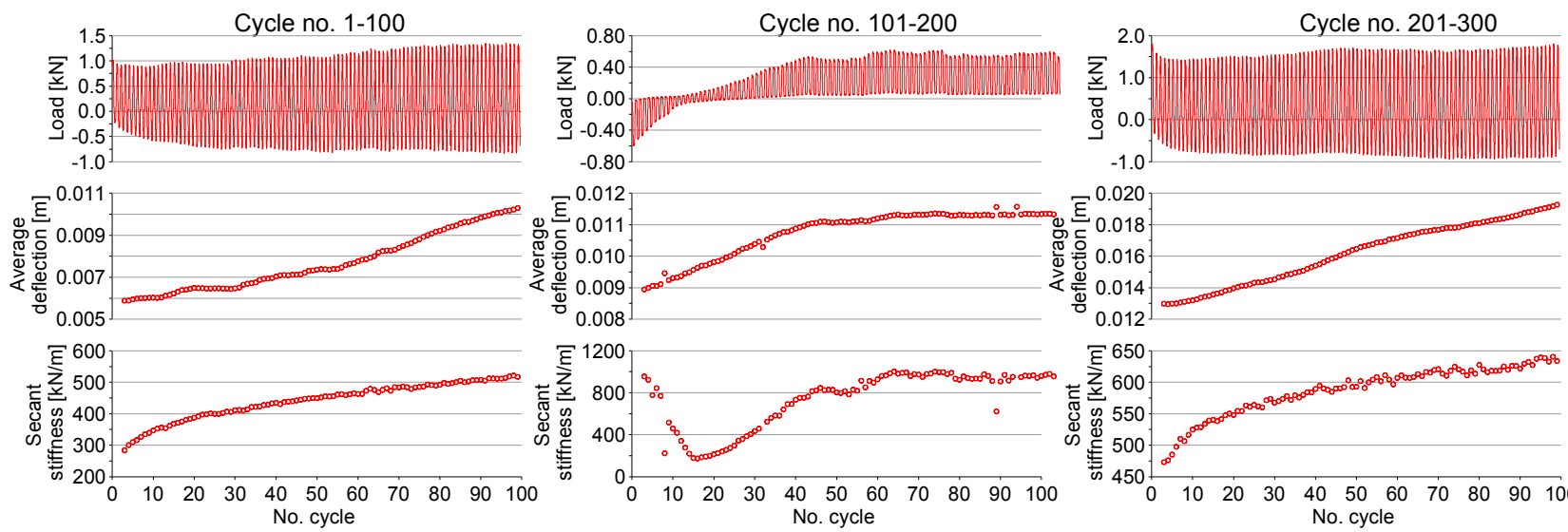

Figure 5.11 Average deflection and secant stiffness vs. number of load cycles for pile with $D=28 \mathrm{~mm}, L=6 D$ and $e=1.43 D$
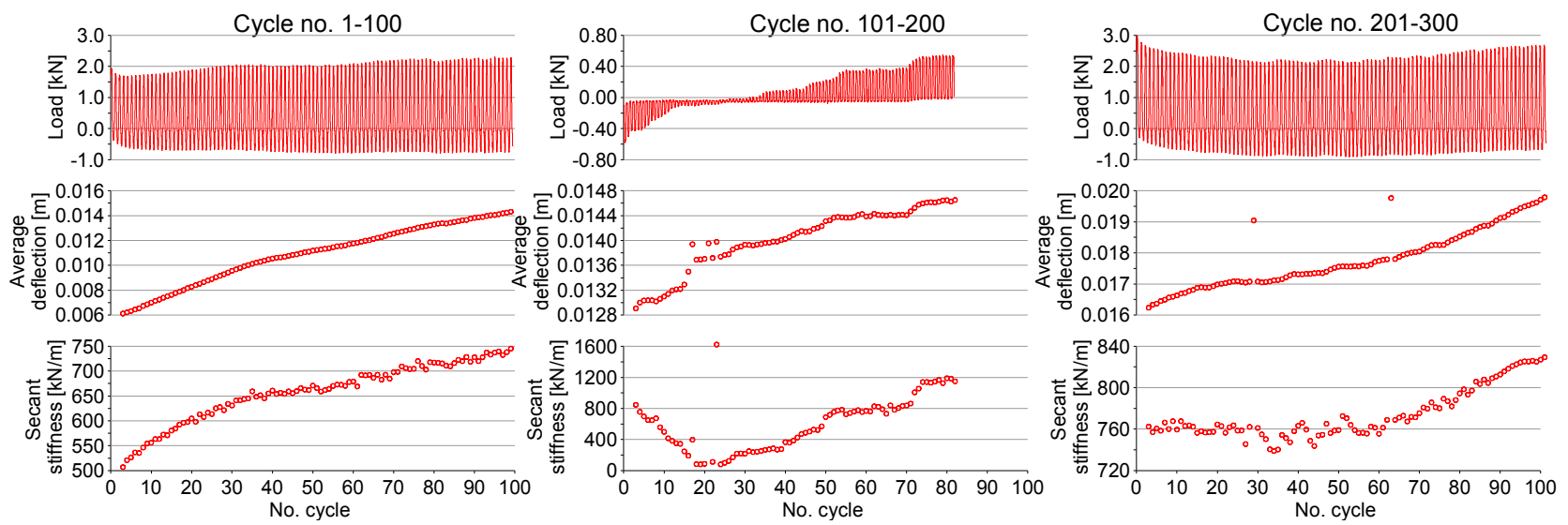

Figure 5.12 Average deflection and secant stiffness vs. number of load cycles for pile with $D=28 \mathrm{~mm}, L=8 D$ and $e=1.43 D$. 

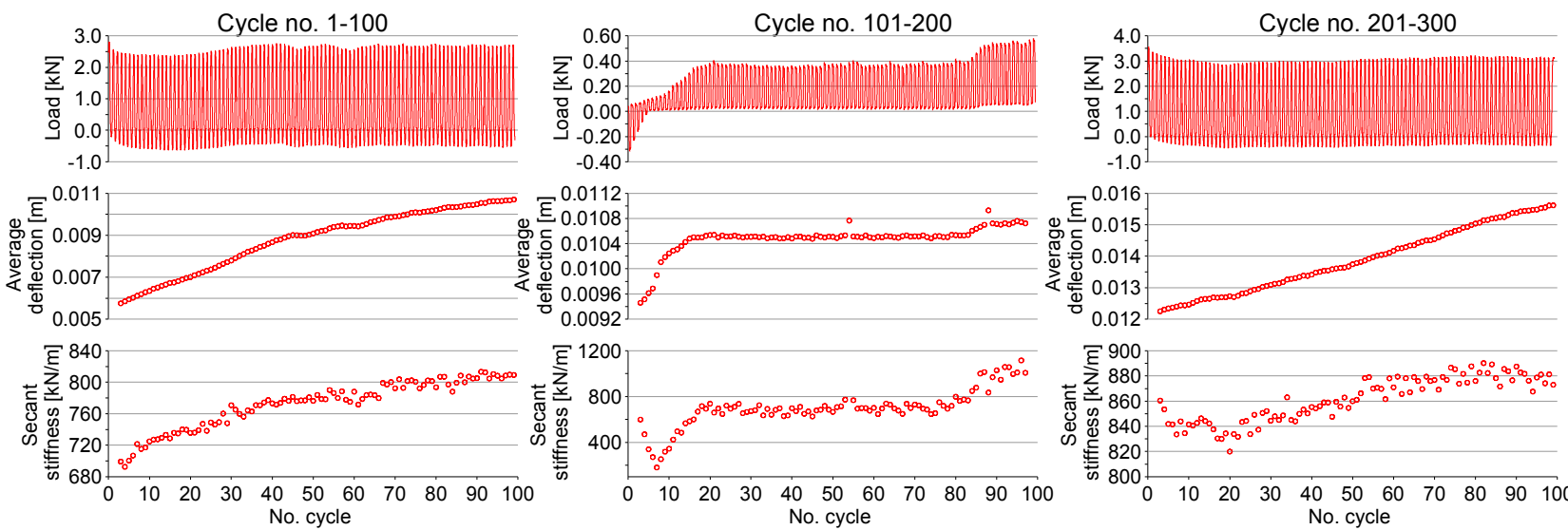

Figure 5.13 Average deflection and secant stiffness vs. number of load cycles for pile with $D=28 \mathrm{~mm}, L=10 \mathrm{D}$ and $e=1.43 D$.

\subsubsection{Cyclic tests on piles with a diameter of $40 \mathrm{~mm}$}

The measured load-displacement curve for the two tests on piles with a model diameter of $40 \mathrm{~mm}$ are presented in Figure 5.14 and Figure 5.15 along with the results from the equivalent static tests (dashed black lines).

Figure 5.14 and Figure 5.15 shows:

- The amplitude of the applied load is for the test with an embedment length of $6 D$ (Figure 5.14) not constant and varies during load cycles.

- The cyclic loading of the pile with an embedment length of $8 D$ seems to stabilise fast, and the load amplitude is relative constant.

- The ultimate capacity has not been reached in either of the post cyclic static tests, but it is based on the available load-displacement curve assessed that the increase in ultimate capacity is approximate $10 \%$

- The post cyclic behaviour of the pile is stiffer compared to the static response. This is interpreted as a result of the compaction in the vicinity of the pile which will take place when it is subject to relative large cyclic loads.

- The first cycle of each cyclic series has a high degree of utilisation compared to the static loading curve. 


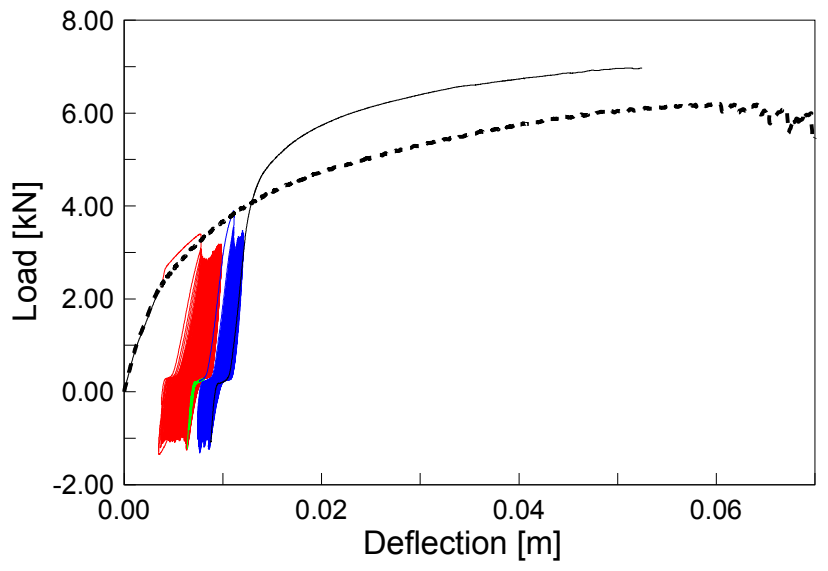

Figure 5.14 Measured load-displacement curve for cyclic test on pile with $D=40 \mathrm{~mm}, L=6 D$, $e^{=}=1 D$.

Equivalent static test is shown with dashed black line.

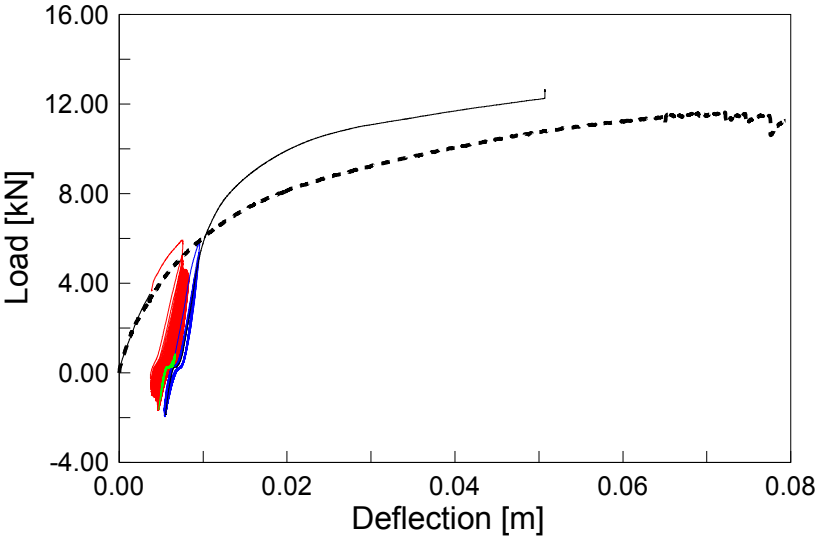

Figure 5.15 Measured load-displacement curve for cyclic test on pile with $D=40 \mathrm{~mm}, L=8 D$, $e=1 D$.

Equivalent static test is shown with dashed black line.

The measured load-displacement curves presented in Figure 5.14 and Figure 5.15 have been analysed and Figure 5.16 to Figure 5.17 shows the curves for the average displacement and secant stiffness vs. load cycle.

It is observed from Figure 5.16 to Figure 5.17:

- Poor control of the test affects the accumulation and change in stiffness. This is most evident for the test on the pile with an embedment length of $6 D$.

- The load amplitude of the second cyclic series seems to be wrong.

- The average deflection increases for the pile with an embedment length of $6 D$, which is interpreted as a consequence of the high load ratio (cyclic loading vs. static load) and poor control.

- The first and third cyclic load series applied to the pile with an embedment length of $8 D$ shows a constant amplitude for $80-90 \%$ of the cycles, and a corresponding stabilising effect with respect to both average deflection and secant stiffness is observed. 

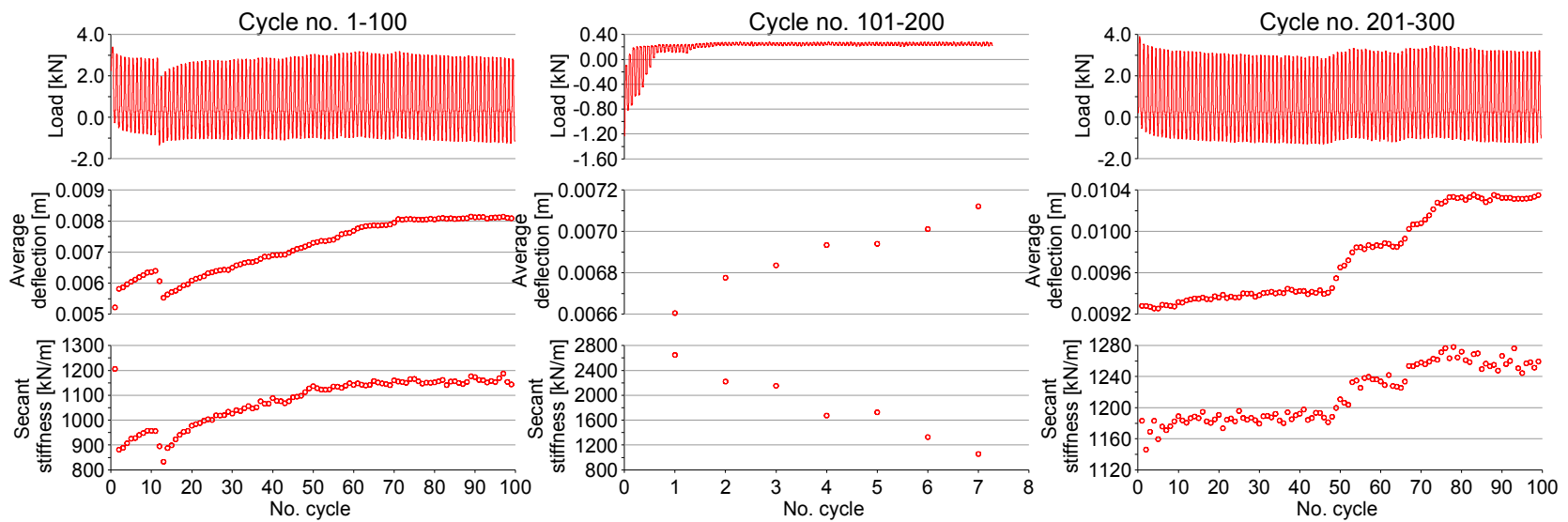

Figure 5.16 Average deflection and secant stiffness vs. number of load cycles for pile with $D=40 \mathrm{~mm}, L=6 D$ and $e=1 D$
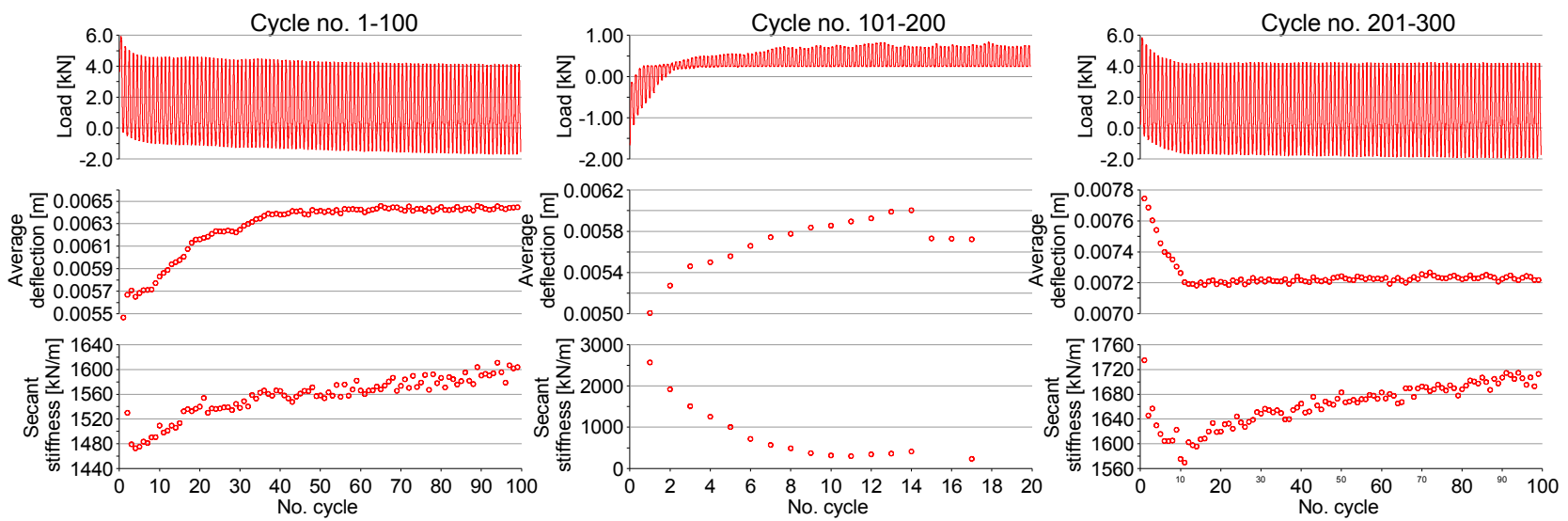

Figure 5.17 Average deflection and secant stiffness vs. number of load cycles for pile with $D=40 \mathrm{~mm}, L=8 D$ and $e=1 D$.

\subsubsection{Post cyclic behaviour}

The measured post cyclic ultimate capacity is for each test given in Table 5.3 along with the static capacity. It is noted that the ultimate capacity has not been reached after cyclic testing of the piles with a diameter of $40 \mathrm{~mm}$, and that the increase is assessed from the load-displacement curves.

Static loading until failure after three series of cyclic loading, reveals for the majority of the modelled piles, an improvement in the ultimate capacity of $10-25 \%$.
Table 5.3 Measured ultimate capacity of piles after cyclic loading.

\begin{tabular}{|c|c|c|c|}
\hline Pile setup & \multicolumn{3}{|c|}{ Ultimate capacity } \\
D/L & $\begin{array}{c}\text { Post cyclic } \\
\text { [N] }\end{array}$ & $\begin{array}{c}\text { Static } \\
\text { [N] }\end{array}$ & $\begin{array}{c}\text { Ratio } \\
{[-]}\end{array}$ \\
\hline $16 \mathrm{~mm} / 6 \mathrm{D}$ & 389 & 326 & 1.19 \\
$16 \mathrm{~mm} / 8 \mathrm{D}$ & 784 & 660 & 1.19 \\
$16 \mathrm{~mm} / 10 \mathrm{D}$ & 1437 & 1271 & 1.13 \\
\hline $28 \mathrm{~mm} / 6 \mathrm{D}$ & 2499 & 2000 & 1.25 \\
$28 \mathrm{~mm} / 8 \mathrm{D}$ & 4248 & 4209 & 1.01 \\
$28 \mathrm{~mm} / 10 \mathrm{D}$ & 6140 & 6964 & 0.88 \\
\hline $40 \mathrm{~mm} / 6 \mathrm{D}$ & $\mathrm{NA}^{*}$ & 6215 & $1.10^{*}$ \\
$40 \mathrm{~mm} / 8 \mathrm{D}$ & $\mathrm{NA}^{*}$ & 11636 & $1.10^{*}$ \\
\hline
\end{tabular}

* Ultimate capacity not reached and improvement is assessed from the load-displacement curves. 
Exception to this is the pile with a diameter of $28 \mathrm{~mm}$ and an embedment length of $8 D$ and $10 D$, which exhibit unchanged capacity and a reduction of $12 \%$, respectively.

\subsection{Summary of cyclic behaviour}

The main conclusions from the cyclic lateral load tests are:

- An examination of all the results from the cyclic tests in Leth (2011) reveal that a number of the tests have been poorly controlled and the apparent conclusion is that the control program contains some flaws which is necessary to improve significant.

- Cyclic loading in general gives a stiffer post cyclic response and increases the ultimate capacity with $10-25 \%$

- The accumulation of deflections and changes in stiffness is highly dependent on the load sequence, and a constant load amplitude leads to stabilisation in the development of average displacements and secant stiffness. 


\section{Conclusion}

\section{Centrifuge facilities:}

It has in connection with the present research been achieved to renovate and update the centrifuge facilities at Danish Technical University (DTU) and ensured a good basis for future research. A series of essential components have been addressed but the single most important part is the introduction a flight $\mathrm{PC}$ on the centrifuge arm, making it possible to move all the test controls and data acquisition to the centrifuge arm. Preparation of dry sand samples have been considered and further improvements of equipment and methods have been carried out, making it possible to prepare and apply homogeneous sand samples for testing.

Existing loading frame for lateral loaded piles has been updated and it is possible to carry out lateral load tests on single piles with a diameter of $40 \mathrm{~mm}$ and pile groups consisting of piles with a diameter of $28 \mathrm{~mm}$.

Static behaviour of large-diameter piles:

The general static behaviour of monopiles in dry sand has based on the centrifuge tests been investigated, with main focus on the initial stiffness and the ultimate pile capacity.

The main findings with respect to static behaviour are:

- The measured behaviour of rigid piles is not described properly by standard $p-y$ curves and exhibit a general softer response towards failure than predicted.

- The standard $p-y$ curves underestimates the pile capacity, and the difference is slightly inverse proportional to the diameter.

- The initial stiffness of the $p-y$ curves depends on the depth below surface and diameter of the pile, with a power dependency for each factor - the initial stiffness varies with the square root of the depth.

Cyclic behaviour of large-diameter piles:

The main focus of the cyclic tests has been to investigate the behaviour of the pile in dry sand with respect to accumulation of deformations and change in secant stiffness.

The main conclusions from the cyclic lateral load tests are:

- The results from the cyclic tests reveal that a number of the tests have been poorly controlled and the apparent conclusion is that the control program contains some flaws which must be improved. 
- Cyclic loading in general gives a stiffer post cyclic response and a $10-25 \%$ increase in the ultimate capacity.

- The accumulation of deflections and changes in secant stiffness is highly dependent on the load sequence, and a constant load amplitude leads to stabilisation in the development of average displacements and change in secant stiffness. 


\section{References}

Achmus, M., Abdel-Rahman, K. \& Kuo, Y.-S. (2007). Numerical Modelling of Large Diameter Steel Piles under Monotonic and Cyclic Horizontal Loading. Proceedings of the 10th International Symposium on Numerical Models in Geomechanics (NUMOG-X) (Pande \& Pietrusczak (eds)). Taylor, London, 2007, pp. 453-460. ISBN: 978-0-415-44027-1

API (2007). Recommended Practice for Planning, Designing and Constructing Fixed Offshore Platforms - Working Stress Design. API recommended practice 2A-WSD (API RP2A-WSD). American Petroleum Institute. Washington D.C. 21. Edition including Errata and Supplement 3, October 2007.

Ashford, S.A. \& Juirnarongrit, T. (2003). Evaluation of Pile Diameter Effect on Initial Modulus of Subgrade Reaction. Journal of Geotechnical and Geoenvironmental Engineering 129, No. 3. (March 2003). Pp. 234-242.

Augustesen, A.H., Sørensen, S.P.H, Ibsen, L.B., Andersen, L., Møller, M. \& Brødbæk, K.T. (2010). Comparison of calculation approaches for monopiles for offshore wind turbines. Proceedings of the 7th European Conference on Numerical Methods in Geotechnical Engineering (NUMGE 2010) (Benz\& Nordal (eds)), Taylor, London, 2010, pp. 901-906.

Barton, Y.O., Finn, W.D.L., Parry, R.H.G \& Towhata, I (1983). Lateral Pile Response and p-y Curves From Centrifuge Tests. Proceedings of the 15th Annual Offshore Technology Conference, Houston, Texas, pp. 503-508. Paper No. 4502.

Breton, S.P. \& Moe, G. (2009). Status, plans and technologies for offshore wind turbines in Europe and North America. Renewable Energy, Volume 34, Issue 3, March 2009, Pages 646-654

Chen, H.T., Lee, C.J. \& Chen, H.W. (1998), The travelling pluviation apparatus for sand specimen preparation. Proceeding for Centrifuge 98, Rotterdam: Balkema, pages 143-148.

Cox, W.R., Reese, L.C. \& Grubbs, B.R. (1974). Field Testing of Laterally Loaded Piles in Sand, Proceedings of the Sixth Annual Offshore Technology Conference, Houston, Texas, pp. 459-472. Paper No. 2079.

Craig. W. H. (1984). Installation studies for model piles. Proceedings of the symposium on application of centrifuge modelling to geotechnical design, pp. 441-456. Rotterdam: Balkema., 1984.

DNV (1992). Foundations. Classification notes No. 30.4. February 1992. Det norske Veritas 1992.

Dyson, G.J. \& Randolph, M.F. (1997), Load transfer curves for piles in calcareous sand, Proceedings of 8th International conference on the behaviour of offshore structures, July 1997 , 
Delft, Netherlands. Vol. 3, pp 245-258.

Dyson, G.J. \& Randolph, M.F. (1998). Installation effects on lateral load-transfer curves in calcareous sands. Proceedings for Centrifuge 98, Rotterdam: Balkema, pages 545-550.

Dyson, G.J. \& Randolph, M.F. (2001). Monotonic lateral loading of piles in calcareous sand, Journal of Geotechnical and Geoenvironmental Engineering, vol. 127, no. 4, pp. 346-352

EWEA (2011). Wind in our sails - The coming of Europe's offshore wind energy industry. November 2011. Prepared by European Wind Energy Association. Available at www.ewea.org

Fan, C.C \& Long, J.H. (2005), Assessment of existing methods for predicting soil response of laterally loaded piles in sand. Computers and Geotechnics 32, pp. 274-289.

Fuglsang, L. (1977), The new centrifuge testing facility at the engineering academy, DIALOG 20th anniversary 77, miscellaneous papers in civil engineering, Danmarks Ingeniørakademi Bygningsafdelingen Lyngby, ISSN 0105-7871.

Fuglsang, L.D. \& Ovesen, N.K. (1988). The application of the theory of modelling to centrifuge studies. Centrifuges in Soil Mechanics (Craig, James \& Schofield (eds.)). Balkema, Rotterdam, pp. 119-138. ISBN 9061918006.

Garnier, J., Gaudin, C., Springman, S. M., Culligan, P. J., Goodings, D. J., Konig, D., Kutter, B. L., Phillips, R., Randolph, M. F. \& Thorel L. (2007). Catalogue of Scaling Laws and Similitude Questions in Geotechnical Centrifuge Modelling. International Journal of Physical Modelling in Ceotechnics 7, Issue 3 (September 2007), pp. 1-23.

Georgiadis, M., Anagnostopoulos, C. \& Saflekou, S. (1992). Centrifugal testing of laterally loaded piles in sand. Canadian Geotechnical Journal 29, No. 2 (April 1992), pp. 208-216.

Haahr, F. (1989), Interaktion mellem tværbelastede model pæle i sand (forsøg i centrifuge), Ph.D. thesis in Danish, Soil Mechanics Laboratory Technical University of Denmark (DTU).

Hald, T., LeBlanc, C., Mørch, C., Jensen, L. \& Ahle, K. (2009). Revisiting monopile design using p-y curves - Results from full scale measurements on Horns Rev. Proceedings of the European Offshore Wind 2009 Conference. Available at www.eow2009.info

Hansen, M.v.G (2008), Examination of forced cable vibrations and their decay - a case study on the Øresund bridge, M.Sc. Thesis, Department of Civil Engineering, Technical University of Denmark.

Klinkvort, R.T. (2009a). Laterally loaded piles - centrifuge and numerically modelling. M.Sc. thesis, Department of Civil Engineering, Technical University of Denmark (DTU). 
Klinkvort, R.T. (2009b). Tværbelastning af monopæl - Geoteknisk datarapport. Data report from Department of Civil Engineering, Technical University of Denmark (DTU Byg), dated 02-072009.

Klinkvort, R.T., Leth, C.T. \& Hededal, O. (2010). Centrifuge modelling of a laterally cyclic loaded pile, Proceedings of the 7th International Conference on Physical Modelling in Geotechnics (ICPMG 2010), 28th June - 1st July, Zurich, Switzerland 2010. Vol. 2 pp 959-964. ISBN-13 9780-415-59288-8.

Knudsen, P.N. (1982). Centrifugeforsøg med tværbelastede pæle - projektering af forsøgsudstyr. M.Sc. thesis in Danish, Laboratoriet for fundering Danmarks Tekniske Højskole.

Larsen, K.A. (2012). Personal communication with Kim André Larsen / AAU December 2012.

Leth, C.T. (2011). Centrifuge modelling of large diameter pile in sand subject to lateral loading, Technical University of Denmark - Department of Civil Engineering, vol. SR 11-09 (UK) Technical report. November 2011. Available from www.orbit.dtu.dk

Leth, C.T., \& Damkilde, L. (2013). Unified model for laterally loaded rigid pile in sand, Submitted for possible publication. August 2013

Leth, C. T., Krogsbøll, A. \& Hededal, O. (2008). Centrifuge facilities at danish technical university. Proceedings of the 15th Nordic Geotechnical Meeting. (NGM2008). Sandefjord Norway. Norsk Geoteknisk Forening., pages: 335-342. ISBN: 978-82-8208-009-5.

Leth, C.T., Sørensen, S.P.H., Klinkvort, R.T., Augustesen, A.H., Ibsen L.B. \& Hededal, O. (2012). A snapshot of present research at AAU and DTU on large-diameter piles in coarse-grained materials. NGM 2012 Proceedings - Proceedings of the 16th Nordic Geotechnical Meeting, Copenhagen, 9-12 May 2012, dgf-Bulletin 27, Danish Geotechnical Society 2012. Vol. 2 pp. 491-498. ISBN 978-87-89833-27-9.

Lesny K. \& Wiemann J. (2006). Finite-Element-Modelling of Large Diameter Monopiles for Offshore Wind Energy Converters. Geo Congress 2006. Atlanta, Georgia, USA.

Li, Z., Haigh, S.K. \& Bolton, M.D. (2010). Centrifuge modelling of mono-pile under cyclic lateral loads. Proceedings of the 7th International Conference on Physical Modelling in Geotechnics (ICPMG 2010) (Springman, Laue \& Seward (eds)). Taylor, London, 2010, pp. 965-970. ISBN 978-0-415-59288-8.

Lin, S.-S. \& Liao J.-C. (1999). Permanent Strains of Piles in Sand due to Cyclic Lateral Loads. Journal of Geotechnical and Geoenvironmental Engineering, vol. 125, no. 9 September 1999, pp. 798-802. 
Long, J.H. \& Vanneste, G. (1994). Effects of Cyclic Lateral Loads on Piles in Sand. Journal of Geotechnical Engineering 120, No. 1, (January 1994), pp. 225-244.

Matlock H. (1970). Correlations of Design of Laterally Loaded Piles in Soft Clay. Proceedings, Second Annual Offshore Technology Conference. Houston, Texas. Paper no OTC 1204. pp 577594.

McClelland, B. \& Focht, J., J.A. (1956). Soil modulus for laterally loaded piles. Journal of the Soil Mechanics and Foundations Division, Vol. 82, No. 4, October 1956, pp. 1-22

Murchison, J.M. \& O'Neill, M.W. (1984). Evaluation of p-y relationships in cohesionless soils. Proceedings of Analysis and Design of Pile Foundations. pp. 174-191.

Papadimitriou, A.G. \& Bouckovalas, G.D. (2002). Plasticity model for sand under small and large cyclic strains: a multiaxial formulation. Soil Dynamics and Earthquake Engineering 22, Issue 3, April 2002, pp. 191-204

Pender, M.J., Carter, D.P. \& Pranjoto, S. (2007). Diameter Effects on Pile Head Lateral Stiffness and Site Investigation Requirements for Pile Foundation Design. Journal of Earthquake Engineering, 11, No. 1, pp. 1-12.

Poulos, H. G. \& Davis, E. H. (1980), Pile foundation analysis and design, John Wiley \& Sons, New York, NY, 1980.

Poulos, H. \& T. Hull (1989). The role of analytical geomechanics in foundation engineering. Proceedings for Foundation Engineering: Current principles and Practices (Kulhawy (ed)), Volume 2, ASCE, pp.1578-1606.

Reese, L.C., Cox, W.R. \& Koop, F.D. (1974). Analysis of Laterally Loaded Piles in Sand, Proceedings of the Sixth Annual Offshore Technology Conference, Houston, Texas, pp. 473-483. Paper No. 2080.

Reese L.C., Cox W.R. \& Koop F.D. (1975). Field Testing and Analysis of Laterally Loaded Piles in Stiff Clay. Proceedings of the Offshore Technology Conference. Paper No. 2312. Dallas, Texas. 1975. pp 671-690

Reese, L.C. \& Matlock, H. (1956). Non-Dimensional Solutions for Laterally Loaded Piles with Soil Modulus Assumed Proportional to Depth. Proceedings 8th Texas Conference on Soil Mechanics and Foundation Engineering. Special Publication No. 29. Bureau of Engineering Research, University of Texas, Austin. Pp 1-41

Rosquöet, F., Thorel, L., Gamier, J. \& Canepa, Y. (2007), Lateral cyclic loading of sand-installed piles. Soils and Foundations, 47, no 5, pp. 821-832. 
Sørensen, S.P.H., L.B. Ibsen \& Augustesen, A.H. (2010). Effects of diameter on initial stiffness of p-y curves for large diameter piles in sand. Proceedings of the 7th European Conference on Numerical Methods in Geotechnical Engineering (NUMGE 2010) (Benz\& Nordal (eds)), Taylor, London, 2010, pp. 907-912.

Taylor, R.N. (ed.) (1995). Geotechnical Centrifuge Technology. Chapman and Hall, London. 1995

UpWind (2007). Assessment of bottom-mounted support structure types with conventional design stiffness and installation techniques for typical deep water sites - Deliverable D4.2.1 - (WP4: Offshore foundations and support structures). Rev. 3 dated March 27th 2007. Available at www.upwind.eu

Verdue, L., Garnier, J. \& Levacher, D. (2003). Lateral cyclic loading of single piles in sand. International Journal of Physical Modelling in Ceotechnics 3, Issue 3 (September 2003), pp. 1728.

Zania, V. \& Hededal, O. (2011). The effect of soil-pile interface behaviour on laterallyloadedpiles. Proceedings of the Thirteenth International Conferenceon Civil, Structural and Environmental Engineering Computing, 2011.

Zhao, Y., Gafar, K., Elshafie, M., Deeks, A., Knappett, J. \& Madabhushi, S. (2006), Calibration and use of a new automatic sand pourer, Proceeding for Physical Modelling in Geotechnics - 6th ICPMG '06, Balkema, pages 265-270. 


\section{List of symbols and constants}

Following is a list of symbols used in the text. Units is defined by: Length $(L)$, Weight $(W)$, Force $(F)$, Time ( $T)$, Degrees (Deg), Radians (Rad)

\begin{tabular}{|c|c|c|}
\hline Symbol & Description & Unit \\
\hline a & $\begin{array}{l}\text { Factor specifying initial stiffness of p-y curve for reference } \\
\text { situation (at depth } \mathrm{x}_{\text {ref }} \text { and diameter } D_{\text {ref }} \text { ) }\end{array}$ & $(\mathrm{F} / \mathrm{L}) / \mathrm{L}$ \\
\hline A & Empiric factor & - \\
\hline $\mathrm{a}_{\mathrm{r}}$ & Radial acceleration & $\mathrm{L} / \mathrm{T}^{2}$ \\
\hline $\mathrm{b}$ & Dimensionless constant & - \\
\hline $\mathrm{c}$ & Dimensionless constant & - \\
\hline $\mathrm{C}_{1}, \mathrm{C}_{2}, \mathrm{C}_{3}$ & Coefficients & - \\
\hline $\mathrm{D}$ & Pile diameter & $\mathrm{L}$ \\
\hline $\mathrm{d}_{50}$ & Average grain size & $\mathrm{L}$ \\
\hline$d_{s}$ & Specific gravity of particles & - \\
\hline $\mathrm{e}$ & Load eccentricity above soil surface & $\mathrm{L}$ \\
\hline$\Delta \mathrm{e}$ & Change in void ratio & - \\
\hline $\mathrm{E}_{0}$ & Initial Youngs modulus & $\mathrm{F} / \mathrm{L}^{2}$ \\
\hline $\mathrm{E}_{50}$ & Youngs modulus at $50 \%$ of ultimate strength & $\mathrm{F} / \mathrm{L}^{2}$ \\
\hline $\mathrm{e}_{\min }$ & Minimum void ratio & - \\
\hline $\mathrm{e}_{\max }$ & Maximum void ratio & - \\
\hline $\mathrm{E}_{\mathrm{p}}$ & Youngs modulus for pile material & $\mathrm{F} / \mathrm{L}^{2}$ \\
\hline $\mathrm{E}_{\mathrm{py}, \mathrm{ini}}$ & Initial stiffness of $p-y$ curve & $(\mathrm{F} / \mathrm{L}) / \mathrm{L}$ \\
\hline $\mathrm{E}_{\mathrm{s}}$ & Youngs modulus for soil & $\mathrm{F} / \mathrm{L}^{2}$ \\
\hline $\mathrm{H}$ & Horizontal force & $\mathrm{F}$ \\
\hline $\mathrm{H}_{\max }$ & Ultimate horizontal capacity of pile & $\mathrm{F}$ \\
\hline $\mathrm{I}_{\mathrm{d}}$ & Relative density & - \\
\hline $\mathrm{I}_{\mathrm{p}}$ & Moment of inertia for pile (a.k.a. second moment of area) & $\mathrm{L}^{4}$ \\
\hline $\mathrm{k}$ & Initial modulus of subgrade reaction & $\mathrm{F} / \mathrm{L}^{3}$ \\
\hline $\mathrm{L}$ & Pile embedment length & $\mathrm{L}$ \\
\hline M & Moment (Load) & FL \\
\hline $\mathrm{N}$ & Scaling factor & - \\
\hline $\mathrm{p}$ & Soil resistance per unit length & $\mathrm{F} / \mathrm{L}$ \\
\hline $\mathrm{p}(\mathrm{x})$ & Soil resistance per unit length at depth $\mathrm{x}$ & $\mathrm{F} / \mathrm{L}$ \\
\hline
\end{tabular}




\begin{tabular}{|c|c|c|}
\hline Symbol & Description & Unit \\
\hline $\mathrm{p}^{\prime}$ & Effective principal stress, $\left(\sigma_{1}^{\prime}+2 \sigma_{3}^{\prime}\right) / 3$ & $\mathrm{~F} / \mathrm{L}^{2}$ \\
\hline $\mathrm{p}_{\mathrm{u}}$ & Ultimate soil resistance per unit length & $\mathrm{F} / \mathrm{L}$ \\
\hline$q$ & Deviatoric stress, $\left(\sigma_{1}-\sigma_{3}\right)$ or $\left(\sigma_{1}^{\prime}-\sigma_{3}^{\prime}\right)$ & $\mathrm{F} / \mathrm{L}^{2}$ \\
\hline $\mathrm{r}$ & Radius & $\mathrm{L}$ \\
\hline $\mathrm{R}^{2}$ & Coefficient of determination & - \\
\hline $\mathrm{R}_{0}$ & Distance from pile tip to level of rotation & $\mathrm{L}$ \\
\hline $\mathrm{u}$ & Lateral displacement of pile head & $\mathrm{L}$ \\
\hline $\mathrm{u}_{\max }$ & Lateral displacement of pile head at ultimate horizontal capacity & $\mathrm{L}$ \\
\hline $\mathrm{U}$ & Uniformity index & - \\
\hline $\mathrm{x}$ & Depth below soil surface & $\mathrm{L}$ \\
\hline $\mathrm{y}$ & Lateral displacement & $\mathrm{L}$ \\
\hline$y(x)$ & Lateral displacement at depth $\mathrm{x}$ & $\mathrm{L}$ \\
\hline$\gamma$ & Unit weight & $\mathrm{F} / \mathrm{L}^{3}$ \\
\hline$\gamma^{\prime}$ & Submerged unit weight & $\mathrm{F} / \mathrm{L}^{3}$ \\
\hline$\theta$ & Rotation of pile & {$[\mathrm{Rad}]$} \\
\hline$\sigma_{1}$ & Major principal total stress & $\mathrm{F} / \mathrm{L}^{2}$ \\
\hline$\sigma_{3}$ & Minor principal total stress & $\mathrm{F} / \mathrm{L}^{2}$ \\
\hline$\sigma_{1}^{\prime}$ & Major principal effective stress & $\mathrm{F} / \mathrm{L}^{2}$ \\
\hline$\sigma_{3}^{\prime}$ & Minor principal effective stress & $\mathrm{F} / \mathrm{L}^{2}$ \\
\hline$\varphi$ & Friction angle & Deg \\
\hline$\omega$ & Angular rotation speed & $\mathrm{Rad} / \mathrm{T}$ \\
\hline Constants & Description & Unit \\
\hline$D_{\text {ref }}$ & Reference diameter & $1.0 \mathrm{~m}$ \\
\hline $\mathrm{g}$ & Gravitational acceleration & $9.81 \mathrm{~m} / \mathrm{s}^{2}$ \\
\hline $\mathrm{p}_{\mathrm{a}}$ & Atmospheric pressure & $100 \mathrm{kPa}$ \\
\hline $\mathrm{X}_{\mathrm{ref}}$ & Reference depth & $1.0 \mathrm{~m}$ \\
\hline
\end{tabular}





\section{Enclosed scientific papers}

I. Leth, C.T., Krogsbøll, A.S. \& Hededal, O. (2008). Centrifuge facilities at Technical University of Denmark. Published in the proceedings of and presented at NGM-2008 (Nordic Geotechnical Meeting), Nordisk Geoteknikermøte nr.15, Sandefjord, 3-6 September 2008, Norway, pp. 335-342.

II. Klinkvort, R.T., Leth, C.T. \& Hededal, O. (2010). Centrifuge modelling of a laterally cyclic loaded pile, Proceedings of the 7th International Conference on Physical Modelling in Geotechnics (ICPMG 2010), 28th June - 1st July, Zurich, Switzerland 2010. Vol. 2 pp 959964. ISBN-13 978-0-415-59288-8.

III. Augustesen, A.H. \& Leth, C.T. (2011). Tvarbelastede pale. Submitted for publication in DGF-Bulletin nr.17 (Dansk Geoteknisk Forening, www.danskgeotekniskforening.dk).

IV. Klinkvort, R.T., Leth, C.T. \& Hededal, O. (2012), Centrifuge modelling of monopiles in dense sand at The Technical University of Denmark, Published in the proceedings of and presented at 2nd European conference on Physical Modelling in Geotechnics (EUROFUGE 2012), Delft, Netherlands, 23.-24. April 2012.

V. Leth, C.T., Sørensen, S.P.H., Klinkvort, R.T., Augustesen, A.H., Ibsen, L.B. and Hededal, O. (2012). A snapshot of present research at AAU and DTU on large-diameter piles in coarsegrained materials. Published in the proceedings of and presented at NGM-2012 (Nordic Geotechnical Meeting), XVIth Nordisk Geoteknikermøde, Copenhagen, 9.-12. May, Denmark. pp. 491-498. 